\title{
TOLERÂNCIA DO PEPINO ENXERTADO À SALINIDADE EM AMBIENTE PROTEGIDO E CONTROLE DA SALINIZAÇÃO DO SOLO
}

\author{
FLÁVIO FAVARO BLANCO
}

\begin{abstract}
Dissertação apresentada à Escola Superior de Agricultura "Luiz de Queiroz", Universidade de São Paulo, para obtenção do título de Mestre em Agronomia, Área de Concentração: Irrigação e Drenagem.
\end{abstract}

PIRACICABA

Estado de São Paulo - Brasil

Dezembro - 1999 


\title{
TOLERÂNCIA DO PEPINO ENXERTADO À SALINIDADE EM AMBIENTE PROTEGIDO E CONTROLE DA SALINIZAÇÃO DO SOLO
}

\author{
FLÁVIO FAVARO BLANCO \\ Engenheiro Agrônomo
}

Orientador: Prof. Dr. MARCOS VINICIUS FOLEGATTI

Dissertação apresentada à Escola Superior de Agricultura "Luiz de Queiroz", Universidade de São Paulo, para obtenção do título de Mestre em Agronomia, Área de Concentração: Irrigação e Drenagem.

\section{PIRACICABA}

Estado de São Paulo - Brasil

Dezembro - 1999 
Dados internacionais de Catalogação na Publicação (CIP) DIVISÃO DE BIBLIOTECA E DOCUMENTAÇÃO - Campus “Luiz de Queiroz”/USP

\author{
Blanco, Flávio Favaro \\ Tolerancia do pepino enxertado à salinidade em ambiente protegido e controle da \\ salinização do solo / Flávio Favaro Blanco. - - Piracicaba, 1999. \\ 104 p. : il \\ Dissertação (mestrado) - - Escola Superior de Agricultura Luiz de Queiroz, 1999. \\ Bibliografia
}

1. Cultivo em estufa 2. Enxertia 3. Irrigação 4. Lixiviação do solo 5. Pepino 6. Salinidade do solo I. Título

CDD 635.63

\title{
"Permitida a cópia total ou parcial deste documento, desde que citada a fonte - O Autor"
}


Aos meus pais, Luiz e Dair, exemplos de vida e humildade, cujo amor eleva-me a cada instante.

MINHA HOMENAGEM

Às minhas irmãs, Márcia e Marli, cunhados e sobrinhos.

OFEREÇO E DEDICO 


\section{AGRADECIMENTOS}

À Deus, Quem me iluminou e deu forças para vencer os obstáculos surgidos durante o percurso.

Ao Departamento de Engenharia Rural da Escola Superior de Agricultura "Luiz de Queiroz", pela oportunidade oferecida para o desenvolvimento deste trabalho.

À Fundação de Amparo à Pesquisa do Estado de São Paulo, pela concessão da bolsa e recursos financeiros utilizados no projeto de pesquisa.

Ao Prof. Dr. Marcos Vinicius Folegatti, pelo apoio dado para a realização deste curso e pela orientação e estímulo no desenvolvimento do trabalho.

Ao Prof. Dr. José Francismar de Medeiros da Escola Superior de Agricultura de Mossoró, pela contribuição na elaboração do projeto de pesquisa e desenvolvimento do tema.

À $\operatorname{Prof}^{\mathrm{a}} \operatorname{Dr}^{\mathrm{a}}$ Maria Cristina Stolf Nogueira, pelo auxílio na definição e execução das análises estatísticas.

Aos Professores Tarlei Arriel Botrel e João Tessarioli Neto, pelas sugestões para o melhoria e engrandecimento deste trabalho.

A todos os professores do Departamento de Engenharia Rural da ESALQ/USP, pelos ensinamentos oferecidos durante a realização do curso.

Aos colegas do Curso de Pós-Graduação em Irrigação e Drenagem, pela amizade, companheirismo e momentos de alegria.

Ao engenheiro agrícola Enio Farias de França e Silva, pelo auxílio nos trabalhos de campo e troca de informações.

Aos funcionários do Departamento de Engenharia Rural da ESALQ/USP, pela colaboração e serviços prestados durante a instalação e execução do experimento em campo.

A todos aqueles que, de uma forma ou de outra, contribuíram para a realização deste trabalho. 


\section{SUMÁRIO}

Página

LISTA DE FIGURAS …................................................................. vi

LISTA DE TABELAS ...................................................................... ix

LISTA DE APÊNDICES ................................................................ xii

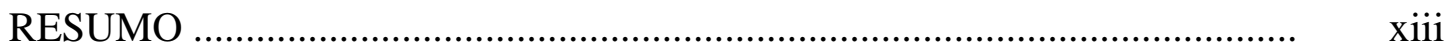

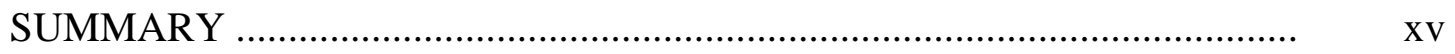

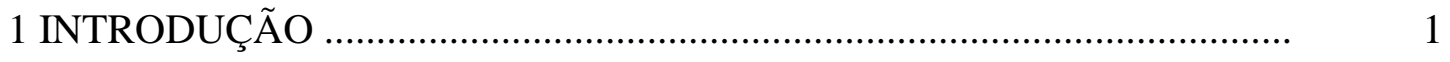

2 REVISÃO DE LITERATURA ......................................................... 3

2.1 Considerações gerais ...................................................................... 3

2.2 Salinidade do solo e tolerância das culturas à salinidade ............................ 4

2.3 Salinidade e crescimento das plantas ................................................... 7

2.4 Qualidade da água de irrigação ......................................................... 8

2.5 Irrigação por gotejamento e fertirrigação ................................................. 10

2.6 Necessidade hídrica e manejo da irrigação em cucurbitáceas .................... 13

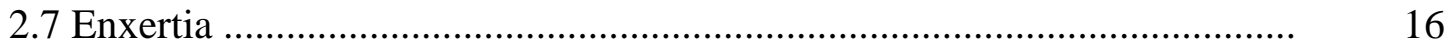

2.8 Controle da salinização do solo e recuperação de solos salinos ................. 17

3 MATERIAL E MÉTODOS .................................................................... 21

3.1 Localização e características da área experimental ................................... 21

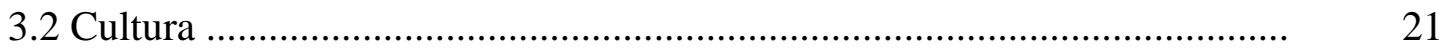

3.3 Descrição das estruturas experimentais .................................................. 21

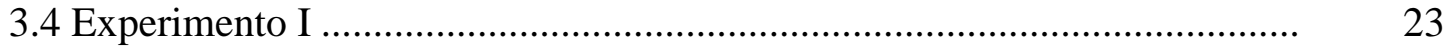

3.4.1 Características químicas e físico-hídricas do solo ................................ 23

3.4.2 Tratamentos e delineamento estatístico ............................................... 25

3.4.3. Sistema de irrigação e equipamentos para manejo da irrigação ............. 27

3.4.4. Controle das irrigações ................................................................... 28 
Página

3.4.5 Preparo das águas de irrigação ……………………………………........ 31

3.4.6 Condução da cultura ........................................................................

3.4.7 Parâmetros avaliados .......................................................................... 34

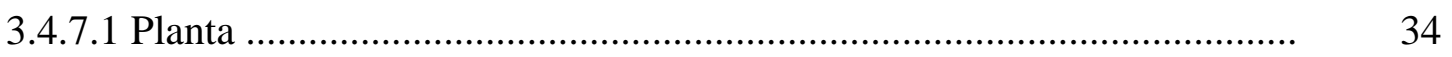

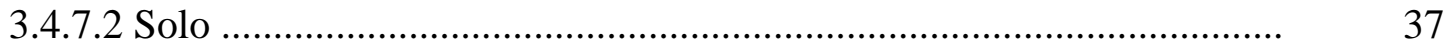

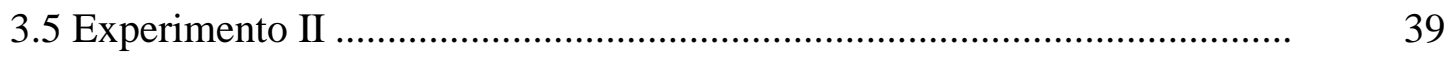

4 RESULTADOS E DISCUSS ÃO …………………………………....... 41

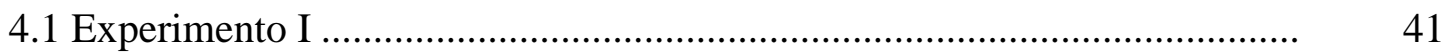

4.1.1 Desenvolvimento vegetativo das plantas ................................................ 41

4.1.1.1 Altura das plantas ........................................................................... 41

4.1.1.2 Diâmetro do colo ..........................................................................

4.1.1.3 Área foliar unitária, índice de área foliar e matéria seca das folhas ..... $\quad 46$

4.1.2 Evolução da salinidade do solo .............................................................

4.1.3 Potencial mátrico ............................................................................... 57

4.1.4 Produção e componentes de produção do pepino enxertado ..................... 59

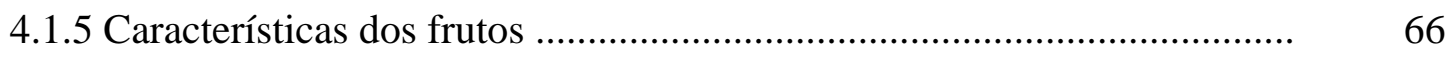

4.1.6 Concentração mineral nas folhas e frutos de pepino e fertilidade do solo $\quad 70$

4.2 Experimento II …….........................................................................

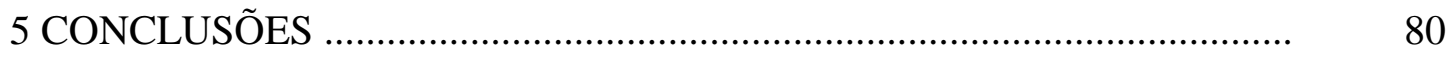

REFERÊNCIAS BIBLIOGRÁFICAS …....................................................... 82

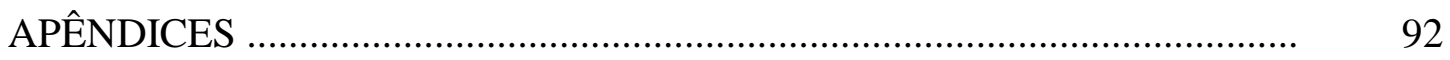




\section{LISTA DE FIGURAS}

Página

$1 \quad$ Estufa utilizada no desenvolvimento do experimento ......................... 22

2 Isolamento das parcelas experimentais para evitar o deslocamento de 23 sais e água para as parcelas adjacentes

3 Croqui da área experimental e configuração do sistema de irrigação .

$4 \quad$ Valores de Kc adotados nas irrigações

5 Lâmina de irrigação prevista e aplicada em função do intervalo de semanas após o transplantio

6 Esquema de uma parcela experimental, indicando as posições dos tensiômetros e plantas úteis .......................................................... 34

7 Relação entre o comprimento e a largura da folha e a área foliar ....... 36

8 Frutos de pepino, demonstrando frutos comerciais (primeira e segunda colunas) e frutos não comerciais (terceira coluna) ................ 37

9 Crescimento das plantas de pepino para cada salinidade da água, lâmina de irrigação e frequência de aplicação da lâmina L1 ...............

10 Diâmetro do colo das plantas de pepino para cada salinidade da água, lâmina de irrigação e frequência de aplicação da lâmina L1 .....

11 Área foliar unitária e Índice de área foliar das plantas de pepino para cada salinidade da água, lâmina de irrigação e frequência de aplicação da lâmina L1

12 Porcentagem de matéria seca das folhas no final do ciclo do pepino ..

13 Perfis de salinidade do solo, expressos em condutividade elétrica do extrato de saturação (CEes), para as diferentes salinidades da água, lâminas de irrigação e frequências de aplicação de L1 aos 20 e 117 dias após o transplantio 
Página

14 Evolução da salinidade do solo em diferentes profundidades para cada salinidade da água de irrigação

15 Evolução da salinidade do solo em diferentes profundidades para cada lâmina de irrigação e frequência de aplicação de L1

16 Evolução da salinidade do solo e salinidade antes e depois da aplicação da lâmina L1, para os tratamentos de frequência F2

17 Perfis de salinidade ao longo do comprimento do canteiro, medidos no final do ciclo da cultura do pepino (plantas localizadas nas posições de 20 e $60 \mathrm{~cm}$, em relação ao comprimento do canteiro) ......

18 Produção comercial e total de pepino para cada salinidade da água, lâmina de irrigação e frequência de aplicação da lâmina L1 ...............

19 Número de frutos comercial e total por planta de pepino para cada salinidade da água, lâmina de irrigação e frequência de aplicação da lâmina L1

20 Peso médio dos frutos comerciais de pepino para cada salinidade da água, lâmina de irrigação e frequência de aplicação da lâmina L1 .....

21 Equações de regressão para produção e número de frutos por planta, comercial e total, em função da salinidade da água de irrigação (CEa)

22 Equações de regressão para produção e número de frutos por planta, comercial e total, em função da salinidade média do solo na região radicular da cultura

23 Relação entre o comprimento e o peso médio e entre o comprimento e o diâmetro médio dos frutos comerciais de pepino

24 Características dos frutos para cada salinidade da água de irrigação ..

25 Características dos frutos para cada lâmina de irrigação

26 Características dos frutos para cada frequência de aplicação da lâmina L1 
27 Salinidade do solo antes e depois da aplicação das lâminas de lixiviação por gotejamento e inundação utilizando diferentes lâminas relativas de lavagem ..................................................................

28 Valores do coeficiente k para os métodos de aplicação da lâmina de lavagem por gotejamento e inundação em função da lâmina aplicada 


\section{LISTA DE TABELAS}

1 Resultados da análise de fertilidade do solo no início do período experimental ........................................................................... 24

2 Parâmetros da equação de retenção de água para cada bloco em diferentes profundidades .......................................................... 25

3 Granulometria e classe textural do solo em diferentes profundidades 26

$4 \quad$ Fatores considerados nas análises estatísticas, com seus respectivos

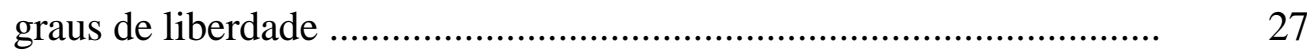

5 Evaporação média diária do tanque Classe A (ECA) no interior da estufa e valores médios do coeficiente de cultivo $(\mathrm{Kc})$ adotados nas irrigações de acordo com o período de dias após o transplantio .......... Quantidades e parcelamento de nutrientes a serem aplicados durante o ciclo de cultivo

7 Resumo da ANAVA para a altura das plantas em quatro épocas distintas, para as diferentes salinidades da água, lâminas de irrigação e frequências de aplicação da lâmina L1

8 Resumo da ANAVA para o diâmetro do colo das plantas em quatro épocas distintas, para as diferentes salinidades da água, lâminas de irrigação e frequências de aplicação da lâmina L1

9 Teste de Dunnett unilateral para a lâmina de irrigação L1, associada à frequência de aplicação (LF), comparadas com a lâmina L0, dentro dos níveis de salinidade, para as medições realizadas aos 96 e 112 dias após o transplantio 
Página

10 Resumo da ANAVA para Área foliar unitária e Índice de área foliar das plantas de pepino em três épocas distintas, para as diferentes salinidades da água, lâminas de irrigação e frequências de aplicação da lâmina L1

11 Resumo da ANAVA e médias da salinidade média do solo nas profundidades de 20, 40 e $60 \mathrm{~cm}$ e da salinidade média final na profundidade de 0-40 cm, para as diferentes salinidades da água, lâmina de irrigação e frequência de aplicação da lâmina L1

12 Resumo da ANAVA e médias do potencial mátrico médio do solo nas profundidades de 15 e $30 \mathrm{~cm}$, bem como do potencial mátrico médio na região radicular, para as diferentes salinidades da água, lâmina de irrigação e frequência de aplicação da lâmina L1 ...............

13 Resumo da ANAVA e médias para o comprimento, diâmetro, relação comprimento/diâmetro e porcentagem de matéria seca dos frutos, para cada salinidade da água, lâmina de irrigação e frequência de aplicação da lâmina L1

14 Faixas ótimas de concentração de nutrientes em folhas de pepino, segundo alguns autores

15 Teores de macro e micronutrientes e PST no solo para cada salinidade da água, lâmina de irrigação e frequência de aplicação da lâmina L1

16 Teores de macro e micronutrientes e sódio nas folhas de pepino no final do ciclo da cultura para cada salinidade da água, lâmina de irrigação e frequência de aplicação da lâmina L1

17 Classificação da concentração de nutrientes nas folhas de pepino de acordo com os níveis ótimos recomendados por alguns autores, em função da salinidade da água de irrigação 
18 Teores de macro e micronutrientes e sódio nos frutos de pepino no final do ciclo da cultura para cada salinidade da água, lâmina de irrigação e frequência de aplicação da lâmina L1 ..............................

19 Salinidade do solo antes da recuperação e lâmina de lavagem aplicada para cada método de aplicação e lâmina relativa de lavagem

20 Resumo da ANAVA e médias da salinidade do solo após a recuperação $(\mathrm{CEF})$, redução da salinidade (CEI-CEF), relação entre a salinidade final e a inicial (CEF/CEI) e coeficiente $\mathrm{k}$ da equação de Rhoades \& Loveday (1990) para os diferentes métodos de aplicação da lâmina e lâminas relativas de lavagem ......................................... 


\section{LISTA DE APÊNDICES}

1 Quantidade de fertilizantes e sais aplicados nas irrigações (g.planta ${ }^{-1}$ ) para as diferentes salinidades da água de irrigação, ao

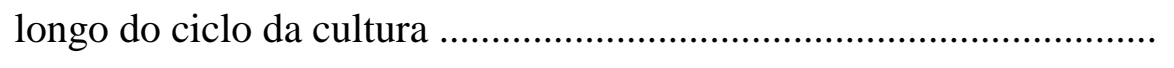

2 Relação entre a altura relativa da planta na qual a folha está inserida e sua respectiva área foliar aos 35 dias após o transplantio, para as nove plantas avaliadas .................................................................

3 Relação entre a altura relativa da planta na qual a folha está inserida e sua respectiva área foliar aos 54 dias após o transplantio, para as nove plantas avaliadas .................................................................. 96

4 Área foliar média para cada altura relativa da folha na planta ............ 98

5 Relação entre a condutividade elétrica do extrato de saturação do solo (CEes) e a condutividade elétrica da solução 1:2 ( $\left.\mathrm{CE}_{1: 2}\right)$, para as

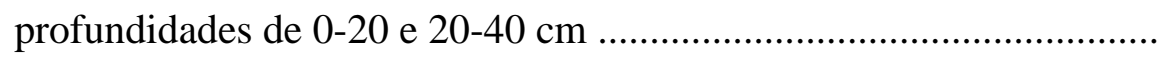

$6 \quad$ Módulo do potencial mátrico nas profundidades de 15 e $30 \mathrm{~cm}$ nos diferentes tratamentos

7 Resumo da ANAVA e médias da produção e numero de frutos por planta, comercial e total, e peso médio de frutos comerciais de pepino, para as diferentes salinidades da água, lâminas de irrigação e frequências de aplicação da lâmina L1 


\title{
TOLERÂNCIA DO PEPINO ENXERTADO À SALINIDADE EM AMBIENTE PROTEGIDO E CONTROLE DA SALINIZAÇÃO DO SOLO
}

\author{
Autor: FLÁVIO FAVARO BLANCO \\ Orientador: Prof. Dr. MARCOS VINÍCIUS FOLEGATTI
}

\section{RESUMO}

A aplicação de fertilizantes via água de irrigação é prática comum para cultivos em ambiente protegido, o que pode resultar na salinização do solo se o manejo da irrigação não for adequado. Com isso, é de grande importância que se estabeleça a tolerância das culturas à salinidade e o controle eficiente da irrigação para cada cultura a fim de se promover a lixiviação do excesso de sais da zona radicular até um nível tolerado pelas plantas. O presente trabalho teve o objetivo de estabelecer um manejo adequado da fertilização e da irrigação para a cultura do pepino enxertado em ambiente protegido, visando o controle da salinidade do solo, e avaliar métodos de recuperação do solo salinizado. Para isso, foi conduzido um experimento em uma estufa de $110 \mathrm{~m}^{2}$ para estudar o efeito de diferentes salinidades da água de irrigação $\left(\mathrm{S} 1=1,58 \mathrm{dS} . \mathrm{m}^{-1}\right.$, $\mathrm{S} 2=3,08 \mathrm{dS} \cdot \mathrm{m}^{-1}$ e $\mathrm{S} 3=5,13 \mathrm{dS} \cdot \mathrm{m}^{-1}$ ), diferentes lâminas de água (L0=1,00.ETc e L1=1,25.ETc) e duas frequências de aplicação da lâmina L1 (F1=em todas as irrigações e F2=quando a lâmina de irrigação acumulada em L0 for igual a $100 \mathrm{~mm}$ ) no desenvolvimento vegetativo e produção do pepino, cv. Hokushin, enxertado em Cucurbita spp., híbrido Excite-Ikki. O manejo da irrigação foi realizado através de tensiômetros instalados a 15 e $30 \mathrm{~cm}$ de profundidade e da evaporação de um tanque reduzido, instalado no interior da estufa. 
Os resultados obtidos demonstraram que o aumento de uma unidade de salinidade da água de irrigação reduziu a produção total e comercial em 2,83 e 2,99\%, respectivamente, não apresentando diferenças significativas. O número de frutos comerciais por planta foi reduzido em $3,32 \%$ para cada incremento de uma unidade de salinidade. A salinidade também afetou significativamente a área foliar unitária e o índice de área foliar, bem como a altura e o diâmetro do colo da planta. As diferentes lâminas de irrigação e frequências de aplicação de L1 não resultaram em diferenças significativas para a produção e componentes de produção da cultura.

$\mathrm{O}$ aumento de uma unidade de salinidade do solo reduziu a produção e o número de frutos por planta, comercial e total, em 7,24 e 6,71\% e 8,04 e 7,58\%, respectivamente, os quais foram bem inferiores aos valores citados na literatura. A pequena redução na produção e a ausência de diferenças significativas entre os níveis de salinidade não permitiram definir a tolerância do pepino à salinidade e o manejo da lâmina de irrigação quando a água utilizada apresenta alto teor salino.

A salinidade do solo aumentou proporcionalmente com o aumento da salinidade da água, sendo que as lâminas de irrigação e as frequências de aplicação de L1 não foram suficientes para reduzir a salinidade do solo, embora a frequência F2 tenha resultado em um aumento mais lento da salinidade.

A lixiviação do excesso de sais do solo após o cultivo demonstrou que a aplicação da lâmina de lavagem por gotejamento foi mais eficiente do que a inundação na redução da salinidade do solo. Concluiu-se que a lâmina relativa de lavagem e o valor do coeficiente $\mathrm{k}$ a serem utilizados são, respectivamente, de 0,9 e 0,1 para gotejamento e 1,3 e 0,2 para inundação, com base na lâmina calculada pela equação de Rhoades \& Loveday (1990). 


\title{
SALINITY TOLERANCE OF GRAFTED CUCUMBER IN GREENHOUSE AND CONTROL OF SOIL SALINIZATION
}

\author{
Author: FLÁVIO FAVARO BLANCO \\ Adviser: Prof. Dr. MARCOS VINÍCIUS FOLEGATTI
}

\section{SUMMARY}

Fertilizers application through irrigation water is a very common practice for greenhouse cultivation conditions, which can result in the soil salinization if irrigation management is not appropriated. It is very important to establish the crop tolerance to salinity and the efficient irrigation control for each crop to promote leaching of excess salts from the root zone until a tolerated level by plants. The present work had the aim to establish an adapted management of fertilization and irrigation for grafted cucumber cultivated in greenhouse, in order to control the soil salinity, and to evaluate methods of salinized soil reclamation. An experiment has been carried out in a $110 \mathrm{~m}^{2}$ greenhouse to study the effects of different irrigation water salinity $\left(\mathrm{S} 1=1,58 \mathrm{dS} . \mathrm{m}^{-1}, \mathrm{~S} 2=3,08 \mathrm{dS} . \mathrm{m}^{-1}\right.$ and $\left.\mathrm{S} 3=5,13 \mathrm{dS} . \mathrm{m}^{-1}\right)$, different irrigation water depth ( $\mathrm{L} 0=1,00 . \mathrm{ETc}$ and $\left.\mathrm{L} 1=1,25 . \mathrm{ETc}\right)$ and two applications frequencies of L1 (F1=at every irrigations and $\mathrm{F} 2=$ when accumulated irrigation water depth in $\mathrm{L} 0$ reaches $100 \mathrm{~mm}$ ) on vegetative development and yield of cucumber, cv. Hokushin, grafted onto Cucurbita spp., hybrid Excite-Ikki. Irrigation management was made by tensiometers installed at 15 and $30 \mathrm{~cm}$ deep and by a reduced pan evaporation, installed inside the greenhouse.

The results showed that the increment of one unit of irrigation water salinity reduced the total and marketable yield at 2,83 and 2,99\%, respectively, not showing 
significantly reduction. Marketable fruits number per plant was reduced at 3,32\% for each increment of one unit of salinity. Salinity also affected significantly the unitary leaf area and the leaf area index, as the height and stem diameter of the plants. The different irrigation water depths and frequencies of L1 application did not result in differences for yield and yield components.

Each increment of one unit of salinity reduced yield and fruit number per plant, marketable and total, of 7,24 and 6,71\% and 8,04 and 7,58\%, respectively, which were smaller than that found on literature. Little reduction in yield and the lack of significantly differences between the levels of salinity did not allow to define cucumber tolerance to salinity and the irrigation management for high salinity irrigation water.

Soil salinity increased proportionally to irrigation water salinity increasing, but irrigation water depths and application frequencies of L1 were not sufficient to reduce soil salinity, though the frequency F2 resulted in a slower increasing of soil salinity.

Leaching of excess salts after cultivation showed that the application of leaching water depth by drip irrigation was more effective than the application by flooding on soil salinity reduction. We concluded that the relative leaching depth and the $\mathrm{k}$ coefficient value to be adopted are, respectively, 0,9 and 0,1 for drip irrigation and 1,3 and 0,2 for flooding, based on water depth calculated by equation of Rhoades \& Loveday (1990). 


\section{INTRODUÇÃ̃O}

Uma tendência na olericultura no Brasil nos últimos anos tem sido a redução do tamanho das áreas cultivadas e o aumento da eficiência das técnicas de cultivo visando maiores produtividades. Além disso, o mercado consumidor está, cada vez mais, exigindo produtos de melhor qualidade e de boa aparência. Os fatores ambientais, como temperatura, chuvas e geadas, podem ocasionar redução significativa na produtividade e na qualidade das hortaliças depreciando-as para o mercado, podendo alcançar $100 \%$ de perdas para o produtor.

Dentro deste contexto, o uso de estufas no cultivo de hortaliças vem assumindo importante papel na agricultura devido à grande adaptação dessas plantas a este sistema de cultivo e ao aumento na lucratividade que proporciona. Entre as culturas mais exploradas em estufa no Estado de São Paulo encontram-se o pimentão, pepino, tomate, alface, entre outras (Trani et al., 1997). O volume total comercializado de tomate, pepino e pimentão no CEAGESP - SP no ano de 1997 foi de 240.403, 38.682 e 38.676 toneladas, respectivamente (FNP CONSULTORIA E COMÉRCIO, 1999).

Embora o uso da água por unidade de produção em estufa seja até 50\% menor em relação ao cultivo em campo aberto (Stanghellini, 1993), devido à maior produtividade em ambiente protegido e a menor demanda evapotranspirativa, o manejo racional da irrigação é de fundamental importância. No Estado de São Paulo, tem-se informações da salinização dos solos de estufa, provavelmente devido ao controle inadequado da lâmina de irrigação, embora a água de irrigação utilizada seja de boa qualidade. Entretanto, a aplicação de fertilizantes em estufa é feita via água de irrigação, o que a torna salina, sendo o nível de salinidade da água diretamente proporcional à quantidade de fertilizante adicionada. Segundo Richards (1954) e Rhoades et al. (1992), 
a qualidade da água de irrigação é definida, principalmente, pela quantidade total de sais dissolvidos e sua composição iônica. Portanto, o conhecimento do comportamento da cultura do pepino em estufa sob diferentes condições de salinidade é fundamental para se desenvolver um manejo eficiente da irrigação e da fertilização. Segundo Maas \& Hoffman (1977) e Gorham (1995), cada espécie, e mesmo cultivares, toleram variavelmente à salinidade.

O controle da salinidade do solo é feito através do balanço de sais na zona radicular, promovendo lixiviação de sais abaixo desta região durante o período de irrigação ou fazendo lavagens do perfil de solo após o cultivo, quando os níveis salinos do solo são prejudiciais às plantas. Para que esta técnica tenha efeito positivo é necessário que o solo tenha drenagem interna adequada.

Devido ao fato da chuva não exercer influência em cultivos sob estufa, apenas a água de irrigação é responsável pelo suprimento de água à cultura e lixiviação dos sais. Para se estabelecer uma lâmina que promova uma lixiviação satisfatória dos sais da zona radicular das culturas, porém sem causar encharcamento e lixiviação excessiva de nutrientes, necessita-se de uma estimativa bastante precisa da evapotranspiração da cultura. Segundo Baille (1992), o monitoramento do balanço hídrico de culturas em ambiente protegido é de importância primordial para o manejo da irrigação.

Com isso, o presente trabalho tem como objetivo o estabelecimento da tolerância do pepino à salinidade em ambiente protegido, estudar a evolução da salinidade do solo ao longo do ciclo da cultura e avaliar métodos de recuperação do solo salinizado após o cultivo. 


\section{REVISÃO DE LITERATURA}

\subsection{Considerações gerais}

Atualmente, estima-se que aproximadamente 955 milhões de hectares de terra estejam afetados por sais em todo o mundo. Segundo Chapman (1975) o continente Australiano se destaca pela grande extensão de terras com problemas de salinização primária (ligada à gênese do solo). Nos Estados Unidos os maiores problemas de salinidade advém de irrigação mal conduzida (sem drenagem eficiente), principalmente na bacia do Great Salt Lake, os vales da Califórnia, a bacia de drenagem do Colorado e Rio Grande, além de partes das bacias do Columbia e do Missouri. Estima-se que no Brasil a área total de solos afetados por sais é superior a 4 milhões de hectares (Szabolcs, 1989). No Nordeste brasileiro, Pereira et al. (1985) estimam em mais de 9 milhões de hectares a área total ocupada pelos solos geneticamente salinos (planossolos, solonetz, solonchack e outros).

Segundo Oliveira (1997) a salinização induzida pelo homem é mais perceptível

em ambientes de elevada taxa de evapotranspiração potencial e baixa precipitação pluviométrica no curso do ano. A salinidade induzida se manifesta em decorrência da irrigação praticada nessas áreas, onde o controle da drenagem não é feito ou feito de forma ineficiente. No nordeste semi-árido, as maiores incidências de áreas salinizadas com salinização secundária se concentram nas terras mais intensamente cultivadas com o uso da irrigação nos chamados Perímetros Irrigados. Chapman (1975) estimou em mais de 25.000 ha de área total salinizada nessa região do Brasil.

A salinização de solos sob cultivo em estufas tem sido um dos principais problemas desse sistema de cultivo. Segundo Trani et al. (1997), recentemente, vem se 
observando uma expansão menos acentuada do cultivo protegido com hortaliças no estado de São Paulo devido aos custos de instalação, manutenção e ao crescimento de pragas e doenças do solo, salinização, bem como a deficiência da pesquisa científica em tecnologia de cultivo protegido para hortaliças. Goto (1997) afirma que é mais fácil reduzir o cultivo em campo aberto do que reduzir o cultivo em ambiente protegido e que, para tanto, é necessário resolver alguns problemas como salinização e fertirrigação, além de incorporar mais tecnologia e abandonar a utilização de práticas de manejo baseadas apenas na análise visual e experiência prática com a cultura explorada.

\subsection{Salinidade do solo e tolerância das culturas à salinidade}

Várias são as causas que podem levar à salinização de um solo. Geralmente, a origem dos sais está relacionada à drenagem deficiente do solo. Sais de elementos alcalino e alcalino-terrosos tendem a se acumular no solo devido à ascensão capilar do lençol freático e evaporação da água, na ausência de lixiviação. A influência de ventos, que carregam sais encrostados na superfície de solos altamente salinos para outras áreas, inundações de áreas cultivadas pela água do mar devido à maré alta e uso excessivo de fertilizantes também podem ser a causa da salinização de um solo.

Segundo Scaloppi \& Brito (1986), o potássio solúvel ou trocável geralmente representa uma pequena proporção mas, ocasionalmente, pode estar incluído entre os principais constituintes da salinidade do solo. Cloreto, sulfato e, menos freqüentemente, nitrato, e pequenas quantidades de bicarbonatos, representam os ânions principais. Além dos sais solúveis, os solos salinos podem conter sais de menor solubilidade, como sulfato de cálcio (gesso) e carbonatos de cálcio e magnésio (calcário). Pelo fato dos colóides estarem floculados, a permeabilidade é igual ou superior à dos solos similares, não salinos.

$\mathrm{O}$ índice que expressa a salinidade é a condutividade elétrica (CE). A condutividade elétrica do solo é determinada através da saturação de uma amostra de solo com água destilada e posterior filtragem à vácuo. Ao volume de líquido filtrado denomina-se estrato de saturação e a condutividade elétrica é chamada de condutividade elétrica do estrato de saturação (CEes), sendo esta recomendada por Richards (1954) 
como o método padrão para avaliar a salinidade do solo em relação ao desenvolvimento das plantas.

Os principais problemas causados pela salinização do solo são a redução do potencial osmótico da solução do solo, diminuindo sua disponibilidade de água e a toxicidade de certos íons às plantas, conforme descrevem Rhoades et al. (1992), Bernardo (1995), entre outros.

Com o aumento da concentração de sais no solo, o potencial osmótico pode tornar-se tão baixo a ponto de ocorrer a perda de água da planta para o solo, processo conhecido como dessecação osmótica. As plantas halófitas, adaptadas a condições salinas, possuem um mecanismo de absorção e acúmulo de sais do solo no vacúolo celular a fim de reduzir o potencial osmótico interno e, desta maneira, evitar a dessecação osmótica. Portanto, os sais não se misturam com a solução citoplasmática, permanecendo no interior do vacúolo, uma vez que a membrana que separa o citoplasma do vacúolo não permite o fluxo de um compartimento para outro, mesmo que haja elevado gradiente de concentração (Läuchli \& Epstein, 1990). Estas plantas, segundo Lima (1997) podem tolerar a uma concentração de até 15 g.l ${ }^{-1}$ de cloreto de sódio, o que corresponde à metade da contração da água do mar.

Por outro lado, plantas glicofitas ou não-halófitas, quando expostas a salinidade moderada, tendem a excluir o excesso de sais pelas raízes, porém não são capazes de realizar o ajuste osmótico, o que resulta no estresse hídrico por osmose (Läuchli \& Epstein, 1990). De acordo com Walter (1961), altos níveis de cloreto na solução do solo provocam o aumento da permeabilidade das raízes, resultando na absorção de grandes quantidades de sais e, consequentemente, ocorre a deterioração de cloroplastos e clorose foliar, seguida de necrose e morte da planta. Läuchli \& Epstein (1990) afirmam que este tipo de injúria é causada pela toxicidade dos íons que, em altas concentrações no citoplasma, danificam enzimas e organelas celulares.

Porém, a tolerância das plantas à salinidade do solo é variável para as diferentes espécies, sendo que as hortaliças, de um modo geral, apresentam-se sensíveis ou moderadamente sensíveis à salinidade do solo. Maas \& Hoffman (1977), publicam uma tabela com o limite da salinidade do solo (CEes) acima da qual começa haver 
redução na produção para cenoura, alface, repolho, pepino, tomate e beterraba, que são, respectivamente, $1,0,1,3,1,8,2,5,2,5$ e $4,0 \mathrm{dS} \cdot \mathrm{m}^{-1}$.

De modo geral, de acordo com Maas \& Hoffman (1977), a produção vegetal decresce linearmente com o aumento da salinidade do solo a partir de determinado nível de salinidade, denominado "salinidade limiar" da cultura. Medeiros (1998) verificou que a redução na produção da cultura do pimentão em estufa foi da ordem de $14 \%$ para o incremento de $1 \mathrm{dS} \cdot \mathrm{m}^{-1}$ na salinidade do solo, acima da salinidade limiar que foi de 1,5 dS.m ${ }^{-1}$, concordando com a tabela apresentada por Maas \& Hoffman (1977).

Sonneveld \& Voogt (1978) submeteram a cultura do pepino a irrigações com água de diferentes salinidades e verificaram que a redução na produção foi de $17 \%$ e $8 \%$ para o aumento de $1 \mathrm{dS} . \mathrm{m}^{-1}$ na água de irrigação e extrato de saturação do solo, respectivamente, visto que a salinidade do solo foi, aproximadamente, duas vezes superior à salinidade da água de irrigação. Em outro experimento, Blanco et al. (1999) concluíram que a redução na produção da cultura da alface em ambiente protegido foi de $17 \%$ para o aumento de uma unidade na salinidade do extrato de saturação do solo.

Respostas positivas do pepino à fertirrigação foram obtidas por Yingjajaval \& Markmoon (1994). Porém, Chartzoulakis (1991), estudando os efeitos da salinidade da água de irrigação na cultura do pepino em estufa, verificou que a altura das plantas, a área foliar total, a produção de frutos e o peso de frutos decresceram e que os teores de sódio e cloreto nas plantas cresceram com o aumento da salinidade acima de 1,2 dS.m ${ }^{-1}$. Maas \& Hoffman (1977) afirmam que a salinidade do solo, expressa como condutividade elétrica do extrato de saturação, à partir da qual o rendimento do pepino começa a ser afetado é de $2,5 \mathrm{dS} . \mathrm{m}^{-1}$, com uma redução de $13 \%$ no rendimento para cada incremento de uma unidade de salinidade. Isso mostra que a tolerância de uma determinada cultura à salinidade pode variar em grande escala, dependendo das condições de cultivo e cultivares utilizadas.

Van den Ende et al. (1975), estudando o efeito da salinidade do solo provocada por quantidades equivalentes de $\mathrm{NaCl}$ e $\mathrm{KNO}_{3}$ no rendimento de diversas culturas, verificou que nos tratamentos que receberam $\mathrm{NaCl}$ a $\mathrm{CEes}$ foi maior que naqueles que receberam $\mathrm{KNO}_{3}$. Os autores afirmam que isto ocorreu devido ao fato de que a absorção 
de potássio e nitrato pelas plantas é maior que a absorção de sódio e cloreto, reduzindo a concentração da solução do solo, e também à desnitrificação do nitrato.

\subsection{Salinidade e crescimento das plantas}

O excesso de sais na solução do solo modifica as atividades metabólicas das células no processo de alongamento celular, limitando a elasticidade da parede celular, reduzindo o alongamento da célula e, como consequiência, o crescimento da planta.

Orteli (1968) afirma que o alongamento da célula vegetal ocorre quando a pressão hidrostática vacuolar interna excede à pressão externa resultante da tensão das paredes e membranas celulares e da pressão exercida pelas células adjacentes. Com isso, a pressão de turgor aumenta e parede da célula ganha elasticidade e plasticidade, permitindo sua expansão. A redução na quantidade de água disponível e conseqüente diminuição na quantidade de água absorvida, combinado com os distúrbios nutricionais provocados pelo meio salino, provocam reduções consideráveis no crescimento das plantas.

Plantas afetadas pela salinidade apresentam desenvolvimento lento e as folhas são menores, apesar de serem mais espessas, que as de plantas normais (Bresler et al., 1982). Plantas sob estresse salino geralmente apresentam folhas de coloração verde mais escura que plantas normais, além da redução do desenvolvimento de frutos. Porém, muitas vezes, a planta pode não exibir nenhum sintoma de estresse salino e apenas a comparação com plantas normais pode revelar a magnitude da inibição causada pelo baixo potencial osmótico do meio ao qual a planta está submetida.

De acordo com Bernstein \& Hayward (1958), a salinidade pode resultar em diferentes efeitos no desenvolvimento e produção da planta, dependendo de fatores como a finalidade da cultura (orgãos vegetativos ou frutos e sementes), o tipo de crescimento (determinado ou indeterminado), a tolerância diferenciada à salinidade nos diferentes estágios de desenvolvimento e outros fatores relacionados.

Para Läuchli \& Epstein (1984), existem dois aspectos quanto ao mecanismo de tolerância à salinidade. Primeiro, se uma glicófita tolerante à salinidade pode realizar o ajuste osmótico para um meio moderadamente salino, as taxas crescentes de absorção e 
transporte de íons e, particularmente, a síntese de solutos orgânicos requerem gastos adicionais de energia, a qual deveria ser utilizada no processo de crescimento. Segundo, o estresse salino é primeiramente sentido pelas raízes, mas o ajuste osmótico, assim como a inibição do crescimento e a toxicidade, são mais perceptíveis na parte aérea da planta. Assim, em adição aos processos celulares, a interação entre o sistema radicular e a parte aérea é parte essencial na resposta da planta à salinidade.

Jones et al. (1989) verificaram que a área foliar e o crescimento das plantas de pepino em estufa reduziram quando a cultura foi irrigada com água de salinidade de 4,0 $\mathrm{dS} . \mathrm{m}^{-1}$, comparada com plantas irrigadas com água de $1,6 \mathrm{dS} . \mathrm{m}^{-1}$.

Chartzoulakis (1994), irrigando o pepino com águas de diferentes salinidades, verificou que a área foliar total das plantas reduziu para salinidades da água de irrigação acima de 2,7 dS.m ${ }^{-1}$, sendo que, para salinidades acima de 5,0 dS.m ${ }^{-1}$, esta redução foi melhor correlacionada com a redução da expansão foliar do que com o número de folhas. A fotossíntese foi reduzida em $50 \%$ para a salinidade de $5,0 \mathrm{dS} . \mathrm{m}^{-1}$, em comparação com o tratamento menos salino $\left(0,3 \mathrm{dS} \cdot \mathrm{m}^{-1}\right)$, enquanto que o crescimento das plantas e o peso seco total foram reduzidos para salinidades acima de $2,7 \mathrm{dS} . \mathrm{m}^{-1}$. Neste trabalho, a salinidade da água de irrigação foi obtida apenas com a adição de $\mathrm{NaCl}$, o que, segundo o autor, levou a um efeito combinado do estresse osmótico e excesso dos íons $\mathrm{Na}^{+}$e $\mathrm{Cl}^{-}$, os quais apresentaram concentrações crescentes nas folhas, proporcionalmente ao aumento da concentração da água.

\subsection{Qualidade da água de irrigação}

Segundo Medeiros \& Gheyi (1994), normalmente a salinidade em áreas irrigadas, é conseqüência do uso de água de qualidade inadequada, associado ao manejo do sistema solo-água-planta e, qualquer que seja sua fonte, a água utilizada na irrigação sempre contém sais, embora a quantidade e a qualidade de sais presentes nela possam variar bastante.

O teor de sais das águas superficiais é função das rochas predominantes nas nascentes, da zona climática, da natureza do solo em que a água flui e de poluições devido à atividade humana. Já no caso de águas subterrâneas, o teor de sais depende da 
origem da água e do curso sobre o qual ela flui, em conformidade com a lei de dissolução, baseada no contato entre a água e o substrato que a armazena. As mudanças no teor de sais da água subterrânea no processo de recarga resulta da redução (geralmente de natureza bioquímica), troca catiônica, evapotranspiração e precipitação (Yaron, 1973).

A quantidade de sais adicionados ao solo pela água de irrigação é proporcional à quantidade de água aplicada. Segundo Van Hoorn \& Van Alphen (1994), a concentração de sais no solo cresce em função da lâmina de irrigação aplicada, até que a salinidade do solo atinja o equilíbrio dinâmico. Segundo Bernardo (1995), atualmente, a principal causa do aumento da salinização dos solos agrícolas tem sido as irrigações mau feitas. Em ambiente protegido, de acordo com Simonis \& Grafiadellis 1 (1985), citados por Chouliaras \& Mavromatis (1990), o excesso de fertilização, o uso de água salina e a ausência de drenagem adequada são fatores que resultam em situações desfavoráveis.

Segundo Biggar et al. (1984), o problema da salinidade em áreas irrigadas torna-se agravado quando o balanço de sais revela uma maior entrada que saída, indicando um acréscimo de concentração salina na área considerada. Nessas condições, a água de irrigação, além de contribuir para o acréscimo da concentração salina, pode também provocar a ascensão do lençol freático que, através de ascensão capilar, passa a fornecer água e sais à zona radicular. Como as plantas absorvem quantidades pouco significativas de sais e a evapotranspiração remove apenas a água, deverá ocorrer um aumento da concentração salina do solo.

Shalhevet (1994) afirma que o processo de acúmulo de sais no solo está intimamente relacionado com o processo de evapotranspiração. Conforme a água é absorvida pelas plantas ou evaporada na superfície do solo, os sais se acumulam.

Segundo Bajwa et al. (1986), a maneira pela qual os sais são transportados e acumulados no perfil do solo depende da quantidade e da qualidade da água de irrigação. Isso, juntamente com os fatores ambientais como evapotranspiração,

\footnotetext{
${ }^{1}$ SIMONIS, A.; GRAFIADELLIS, M. The effect of soil salinity degree on the yield of crops growing in
} greenhouses. Bulletin of Agricultural Centre of North Greece, v.1, p.70-78, 1985. 
sequiência de cultivos e intensidade e distribuição das chuvas, promovem o desenvolvimento de um perfil salino característico para diferentes tipos de solo. Os mesmos autores, estudando diferentes rotações de culturas envolvendo milho, trigo, arroz e milheto, verificaram que independentemente das culturas utilizadas na rotação, o uso contínuo da água salina aumentou a condutividade elétrica do estrato de saturação em todo o perfil do solo, quando comparado com a testemunha (água de boa qualidade). A movimentação ascendente e o acúmulo dos sais nas camadas superficiais ocorreram principalmente durante o período em que a evaporação do tanque Classe A foi maior que a precipitação pluviométrica.

Jones et al. (1989) verificaram que a produção relativa do pepino em ambiente protegido, irrigado com água de salinidade de 4,0 dS.m ${ }^{-1}$, variou de 0,32 a 0,80 entre os diferentes cultivares utilizados, em comparação com plantas irrigadas com água de boa qualidade $\left(1,6 \mathrm{dS} \cdot \mathrm{m}^{-1}\right)$, indicando existir variabilidade genética para tolerância à salinidade dentro dos cultivares. A redução na produção foi devida à redução no número de frutos produzidos, sendo que a produção comercial e o formato dos frutos não foram alterados.

Em ambiente protegido, Blanco \& Folegatti (1999) reportam que mesmo quando se utiliza água de irrigação de boa qualidade e concentrações adequadas de fertilizantes, pode ocorrer o acúmulo de sais na região radicular se não forem adotadas medidas de controle.

\subsection{Irrigação por gotejamento e fertirrigação}

A crescente demanda por alimentos, problemas com escassez de terras cultiváveis próximas a grandes centros consumidores, água de boa qualidade, salinidade do solo, poluição ambiental, problemas fitossanitários e a globalização de mercados fazem com que a produção de hortaliças no Brasil, em futuro próximo, seja altamente tecnificada para ser competitiva (Silva et al., 1999). A aplicação de fertilizantes via água de irrigação, especialmente quando realizada por meio de sistemas de irrigação eficientes, como é o caso do gotejamento, permite a otimização da utilização dos nutrientes pelas plantas. 
De acordo com Gomes (1994), no bulbo úmido irrigado se concentram os sais minerais fornecidos pela água, além dos sais já contidos no solo. O esforço ou tensão total que as raízes da planta devem exercer para extrair água do solo é igual à soma da tensão osmótica, decorrente da dissolução dos sais na água, e da tensão matricial, provocada pela força que as partículas de solo exercem sobre a água. Como na irrigação por gotejamento a umidade do solo se mantém próxima à capacidade de campo, então, para uma mesma tensão total tolerável pela planta, a cultura suportará uma maior concentração de sais dissolvidas no solo. Assim sendo, através da irrigação por gotejamento pode-se irrigar com águas mais salinas em comparação às águas recomendadas para os demais métodos de irrigação.

A prática da fertirrigação pode proporcionar diversas vantagens em relação à adubação via solo. Segundo Frizzone et al. (1994), as principais vantagens da fertirrigação são a facilidade na incorporação do fertilizante, redução da compactação do solo, economia na quantidade de fertilizantes aplicada, redução da contaminação ambiental, redução do custo de aplicação, dentre outras. Os mesmos autores recomendam que a condutividade elétrica máxima da água de irrigação na saída dos gotejadores deve ser inferior a 2,3 dS.m ${ }^{-1}$ quando os fertilizantes são aplicados em todas as irrigações.

De acordo com Nogueira et al. (1998), a implicação da salinidade sobre a fertirrigação destaca-se pela capacidade de incrustação e/ou corrosão da água, além da dificuldade de dissolução de alguns fertilizantes menos solúveis, o que é possível ocorrer na presença acentuada de outros sais na água de irrigação. Mesmo assim, como a maioria dos fertilizantes é bastante solúvel, a salinização desempenha papel importante quando os sais são de baixa solubilidade e, na presença de fertilizantes, tendem a precipitar-se e obstruir a tubulação.

Aplicações excessivas de fertilizantes, utilização de água salina e o formato do bulbo molhado na irrigação por gotejamento, fazem com que haja acúmulo de sais na superfície do solo e na periferia do bulbo. Em cultivo protegido, com características mais intesivas de utilização do solo, a aplicação de fertilizantes e o manejo do solo e da 
irrigação devem ser realizados de forma adequada a fim de evitar o acúmulo excessivo e prejudicial de sais (Carrijo et al., 1999).

Chartzoulakis \& Michelakis (1990) verificaram que a o método de irrigação utilizado teve influência na eficiência de utilização de água pelo pepino, resultando em produtividades de $27,7 \mathrm{~kg} \cdot \mathrm{m}^{-3}$ e $16,8 \mathrm{~kg} \cdot \mathrm{m}^{-3}$ de água aplicada por gotejamento e sulcos, respectivamente. Olitta \& Minami (1974) e Vieira \& Manfrinato (1974) obtiveram incrementos na produtividade do morangueiro e beringela da ordem de $96 \%$ e $67 \%$, respectivamente, quando irrigado por gotejamento, comparados com a irrigação por sulcos.

Segundo Stanley \& Maynard (1990), o manejo da irrigação é importante não apenas para suprir as plantas de água, mas também para permitir às plantas a absorção dos nutrientes necessários para a otimização da produção. Considerando que a necessidade de nutrientes é variável de acordo com o estágio fisiológico da planta, o parcelamento da adubação torna-se necessário para garantir a absorção equilibrada e minimizar as perdas destes nutrientes por lixiviação e volatilização.

Pinto et al. (1993), reportam que a irrigação por gotejamento oferece maior flexibilidade à fertirrigação, promovendo a melhoria na eficiência do uso dos fertilizantes, reduzindo perdas dos nutrientes por lixiviação, condicionando a um melhor controle da concentração de nutrientes no solo e economizando mão-de-obra e energia. Os mesmos autores, estudando o efeito da aplicação de nitrogênio e potássio via água de irrigação na cultura do melão, verificaram que as maiores produções de frutos comerciais $(26,40$ e $25,89 \mathrm{t} / \mathrm{ha})$ ocorreram nos tratamentos em que o $\mathrm{N}$ e $\mathrm{K}$ foram aplicados diariamente, via água de irrigação.

O controle da concentração de solutos em um volume restrito de solo próximo à região radicular das plantas tem possibilitado a aplicação de estresse osmótico em culturas sob irrigação localizada para aumentar a qualidade do produto sem causar grandes perdas de produtividade. Plaut \& Meiri' (1988), citados por Bar-Yosef (1999), estudando os efeitos da irrigação com água salina no tomateiro em ambiente protegido,

\footnotetext{
${ }^{2}$ PLAUT,Z; MEIRI, A. Effect of salinity in irrigation water on yield and fruit quality of greenhouse grown tomatoes during the winter. Israel Agricultural Research, v.2, p.79-97, 1988.
} 
verificaram que o potencial osmótico, analisado isoladamente, não pôde explicar a melhoria na qualidade dos frutos obtida, uma vez que a aplicação do cloreto de sódio foi mais efetiva que a aplicação de cloreto de potássio, melhorando o sabor e firmeza dos frutos.

\subsection{Necessidade hídrica e manejo da irrigação em cucurbitáceas}

O manejo da irrigação em uma cultura é realizado visando manter a camada de solo correspondente à profundidade efetiva do sistema radicular em uma umidade próxima à capacidade de campo. Segundo Klepper (1990), a capacidade das raízes em explorar o solo depende das características físicas e químicas do solo, tais como o impedimento mecânico ao crescimento das raízes, umidade do solo, textura do solo e fertilidade. Carlesso (1995) afirma que a profundidade final de extração pode ser até 0,40 m mais profunda que a profundidade total das raízes, devido ao movimento ascendente de água no solo e aos erros cometidos na determinação da profundidade do sistema radicular, o que é atribuído à baixa precisão dos métodos tradicionais de amostragem.

Chartzoulakis \& Michelakis (1990), irrigando o pepino por sulcos e gotejamento, verificaram que a distribuição de raízes com o aumento de profundidade foi semelhante para os dois sistemas, sendo a profundidade efetiva de $0,30 \mathrm{~m}$, onde aproximadamente $80 \%$ do sistema radicular estava localizado. Loomis \& Crandall (1977) concluíram que a profundidade efetiva das raízes do pepino irrigado por aspersão foi de $0,90 \mathrm{~m}$. Porém, a análise do padrão de extração de umidade demonstrou que este foi de 50, 30 e 10\% para as profundidades de 0-0,30, 0,30-0,60 e 0,60-0,90 m, respectivamente, e $10 \%$ a profundidades superiores a $0,90 \mathrm{~m}$. Portanto, $80 \%$ da absorção total de água ocorreu na profundidade de 0-0,60 m e, para fins de manejo da irrigação, esta seria a profundidade efetiva do sistema radicular a ser considerada.

Segundo Hernandez (1995), em plantas de melão irrigadas por gotejamento, $80 \%$ do sistema radicular encontra-se na camada de $0-0,10 \mathrm{~m}$ de solo, o que torna necessário uma alta freqüência de irrigação. Para efeito de cálculo, segundo Marouelli et al. (1986), pode-se considerar $30 \mathrm{~cm}$ a profundidade efetiva das raízes, embora o ideal 
seja considerar as profundidades efetivas para cada etapa do ciclo da cultura, visto que as raízes crescem com o desenvolvimento da planta.

Outro fator envolvido na determinação da quantidade de água a ser aplicada é a evapotranspiração da cultura. A medição direta da evapotranspiração é extremamente difícil e onerosa, pois exige instalações e equipamentos especiais, sendo que tais estruturas são de alto custo. Existem diferentes métodos de estimativa da evapotranspiração das culturas, sendo que muitos deles têm aceitação quase unânime, enquanto que outros são bastante criticados e até desprezados (Pereira et al., 1997). O método do tanque Classe A é um método bastante utilizado e recomendado pela FAO (Doorenbos \& Pruitt, 1977).

Eliades (1988), em estudo realizado em estufa com pepino visando determinar a lâmina de irrigação mais apropriada para a cultura, verificou que a demanda evapotranspirativa deve ser totalmente reposta e que variou de 0,2 a 1,1 vezes a evaporação do tanque Classe $\mathrm{A}$ instalado fora da estufa, do início ao final do cultivo. $\mathrm{O}$ autor também reporta que o menor rendimento no primeiro cultivo pode estar associado à salinidade da água de irrigação, que foi de $1,3 \mathrm{dS} \cdot \mathrm{m}^{-1}$, contra $0,7 \mathrm{dS} \cdot \mathrm{m}^{-1}$ no segundo ano.

A evaporação do tanque Classe A medida no interior da estufa é menor do que em campo aberto (Farias et al., 1994). Martins (1992) verificou que a evaporação do tanque sob cobertura plástica foi cerca de 30\% inferior à do tanque em campo, o que contribuiu para uma menor evapotranspiração no interior da estufa.

Segundo Montero et al. (1985), a menor evapotranspiração em ambiente protegido é devido, principalmente, à parcial opacidade do filme plástico à radiação e à redução da ação dos ventos, que são os principais fatores da demanda evaporativa da atmosfera, embora a temperatura do ar e a umidade relativa, em alguns momentos, possam ser maior e menor, respectivamente, no interior da estufa do que a céu aberto, o que contribuiria para uma maior evapotranspiração. Blanco \& Folegatti (1998) obtiveram alta correlação $\left(r^{2}=0,99\right)$ entre a radiação global medida em uma estação meteorológica padrão e no interior da estufa, o que contribuiu para uma estimativa mais precisa da evapotranspiração pelo método da Radiação Solar (Doorenbos \& Pruitt, 
1977), comparado com a evapotranspiração estimada pelo tanque Classe A. Em média, os valores de temperatura média do ar, umidade relativa e radiação global observados na estufa corresponderam a 111, 89 e 70\% dos observados no posto meteorológico, respectivamente.

Martínez-Raya \& Castilla (1989), estudando a evapotranspiração de pimentão em ambiente protegido, concluíram que a evaporação do tanque Classe A medida no interior da estufa e o coeficiente de cultivo da FAO estimaram razoavelmente a evapotranspiração da cultura até 100 dias após o transplantio, utilizando um coeficiente de tanque $(\mathrm{Kp})$ igual a 1,0 e para períodos em que a temperatura foi superior a $10^{\circ} \mathrm{C}$. Resultados semelhantes foram obtidos por Castilla et al. (1990) para pepino, melão, melancia e feijão.

Em experimento em ambiente protegido, Loomis \& Crandall (1977) verificaram que o consumo de água por planta de pepino foi de, aproximadamente, 31 litros por planta para um período de cultivo de 60 dias. Os autores enfatizam que o Kc da cultura foi muito superior ao da maioria das culturas, o que indica que, embora o pepino seja uma cultura que apresenta alta eficiência de utilização de água, grande quantidade de água é necessária no período de colheita para suprir as necessidades hídricas da planta.

Mannini (1988) realizou um experimento para determinar o melhor esquema de manejo da irrigação para o pepino em ambiente protegido para a região norte da Itália. Foram testados dois intervalos entre irrigações (3 e 6 dias) e três coeficientes de cultivo $(0,5,1,0$ e 1,5), sendo a evapotranspiração de referência estimada pela evaporação do tanque Classe A, utilizando-se um coeficiente de tanque igual a 0,85. O intervalo entre irrigações não apresentou diferença significativa na produtividade, enquanto que para as diferentes frações de água aplicadas, o aumento no rendimento da cultura foi proporcional ao aumento do volume de água aplicado, resultando em 94,7, 119,3 e 125,6 Mg.ha ${ }^{-1}$, respectivamente.

Lakshmanan \& Tajuddin (1990), verificaram que a máxima produção de abóbora (Cucurbita moschata Poir.) e melão foi obtida quando a irrigação foi realizada 
com o solo apresentando 50 e 75\% de água disponível, respectivamente, tendo sido testados os níveis de $25,50,75 \%$ e irrigação diária.

Callebaut et al. (1985) utilizaram apenas um coeficiente de cultivo (Kc) durante todo o ciclo da cultura e compararam os Kc's de 0,29, 0,47, 0,65 e 0,92. O maior rendimento comercial foi obtido com o Kc de 0,47, seguido por 0,65, 0,92 e 0,29. Porém, devido à grande variabilidade nos dados de produtividade, não foi encontrada diferença significativa entre os tratamentos, tornando difícil a identificação precisa da lâmina ótima de irrigação para a cultura. Com isso, os autores concluem que a produção ótima pode ser obtida com a aplicação de 277 a $484 \mathrm{~mm}$ de água durante o ciclo sem haver grandes perdas na produção comercial quando a quantidade de água aplicada é reduzida.

Freitas \& Bezerra (1999), irrigando a cultura da melancia por gotejamento, verificaram que, em média, a evapotranspiração total no ciclo da cultura foi de $287 \mathrm{~mm}$ para uma lâmina de irrigação total de $343 \mathrm{~mm}$.

\subsection{Enxertia}

A enxertia é uma técnica de propagação de plantas que visa, principalmente, reduzir o tempo de formação de mudas, adaptação a diferentes tipos de solo, precocidade de produção e resistência a doenças. Esta técnica é muito difundida na fruticultura, sendo também utilizada para conferir resistência a nematóides e fungos de solo em algumas hortaliças, principalmente pepino e tomate.

A prática da enxertia em hortaliças vem sendo utilizada há mais de dez anos no Japão, onde 96\% do pepino cultivado em estufa é enxertado (Oda, 1995), e, no Brasil, acredita-se que a enxertia começou na década de 80, embora não existam dados estatísticos sobre a evolução da prática. A enxertia em pepino acredita-se ter começado em 1965 com o objetivo de prevenir a ocorrência da doença causada por Fusarium oxysporum e nematóides (Cañizares, 1998). De acordo com Lima et al. (1995), a enxertia do pepino em abóbora em ambiente protegido tem dado bons resultados, e este porta-enxerto apresenta resistência aos fitonematóides. No estado de São Paulo, tem-se 
informações de que a enxertia pode proporcionar um período de colheita de até 120 dias, sendo este de 50 a 70 dias, em média, para o pepino não enxertado.

A enxertia envolve a união de partes de plantas por meio da regeneração de tecidos, na qual a combinação resultante atinge a união física que lhe permite desenvolver como uma única planta. Para tanto, é necessário que o tecido cambial do enxerto e porta-enxerto estejam em íntima associação, de sorte que o tecido do portaenxerto se entrelace, formando uma conexão contínua (Cañizares, 1998). Oda et al. (1993) verificaram que o aumento na diferença do diâmetro do hipocótilo entre o enxerto e porta-enxerto reduziu consideravelmente a taxa de sobrevivência de mudas de pepino enxertadas sobre abóbora.

Segundo Papadopoulos (1994) a enxertia em pepino é um fator limitante na maximização da produção e pode ser uma alternativa para reduzir o custo com a esterilização do solo. Cañizares \& Goto (1998) obtiveram um aumento na produtividade dos cultivares Nikkey e Ancor em 9,7 e 21,9\%, respectivamente, quando enxertados sobre abóbora híbrida "Ikki”, em relação às plantas que não foram enxertadas.

O pepino, quando enxertado, tem sua produção consideravelmente aumentada, apesar de alguns porta-enxertos induzirem o aumento do vigor da copa (Janowski \& Skapski, 1986). Cañizares \& Goto (1998) verificaram que o porta-enxerto "Tetsukabuto" aumentou a a produtividade do cultivar Ancor em 5,4\% e diminuiu a de Nikkey em 15,6\%, provavelmente, segundo os autores, devido ao aumento no vigor vegetativo do enxerto causado pela enxertia sobre este híbrido de abóbora.

Liebig (1986), estudando os efeitos da temperatura no pepino, concluiu que a enxertia pode ser recomendada como forma de conferir tolerância às plantas a períodos curtos de frio. As plantas enxertadas sobreviveram a uma temperatura de $10^{\circ} \mathrm{C}$, enquanto que a temperatura mínima suportada pelas plantas não enxertadas foi de $14^{\circ} \mathrm{C}$.

\subsection{Controle da salinização do solo e recuperação de solos salinos}

Sob condições irrigadas, muitas vezes os sais podem elevar a salinidade do solo resultando numa salinidade maior do que a desejada. Com o aumento na quantidade de água aplicada em cada irrigação, o nível de salinidade do solo pode ser 
reduzido devido ao aumento do volume de água percolado abaixo da região radicular da cultura (Petersen, 1996).

Segundo Ayers \& Westcot (1985), a lixiviação é a solução para se controlar o problema da salinidade da água. Francois (1981), estudando a cultura da alfafa, observou que estas plantas conduzidas sob condições salinas e na ausência de lâmina de lixiviação apresentaram drástica redução na produção e níveis elevados de $\mathrm{Na}, \mathrm{Cl}$ e $\mathrm{Ca}$, e baixos níveis de K. Bajwa et al. (1986), concluíram que a lixiviação pareceu ser suficiente para controlar o aumento dos sais solúveis no perfil de um solo bem drenado.

A intoxicação das plantas por determinados íons, sob condições salinas, pode causar danos irrecuperáveis às mesmas. Hsiao (1985), estudando o efeito da salinidade na taxa fotossintética do algodoeiro, observou que após a lixiviação dos sais do solo a capacidade fotossintética foi recuperada, embora os íons cloreto e sódio ainda permaneceram acumulados nas folhas. Por outro lado, plantas de feijão submetidas à mesma salinidade não recuperaram sua capacidade fotossintética e suas folhas apresentaram danos irreversíveis mesmo após a remoção dos sais do solo através da lixiviação.

Segundo Lyle et al. (1986), o aumento da lâmina de lixiviação é necessário sempre que houver um aumento da salinidade da água de irrigação. Ayers \& Westcot (1985), afirmam que a quantidade de lixiviação requerida depende da qualidade da água de irrigação e da tolerância da cultura à salinidade. Conforme observado por Vermeiren \& Jobling (1984), a fração mínima da irrigação total necessária para lixiviação sob condições de alta frequiência de irrigação e água com $\mathrm{CE}=2,2 \mathrm{dS} . \mathrm{m}^{-1}$ é de $5 \%$ para trigo e sorgo e de 10 a $15 \%$ para alface.

Medeiros (1998), em experimento com a cultura do pimentão em ambiente protegido, verificou que a aplicação de lâminas 15 e 30\% superiores àquela necessária para repor a evapotranspiração da cultura não foi suficiente para reduzir a salinidade do solo no final do ciclo da cultura, quando comparadas com o tratamento que não recebeu a lâmina de lixiviação. Neste trabalho, as diferentes frações de lixiviação foram aplicadas em todas as irrigações, a qual teve uma frequência média de 2 dias. Segundo Meiri \& Shalhevet (1973), lixiviações realizadas em todas as irrigações são menos 
efetivas no controle da salinidade do solo do que aquelas realizadas com baixa freqüência.

A evapotranspiração da cultura pode provocar a redução da eficiência de lixivação, visto que as plantas absorvem água durante o processo de infiltração e redistribuição, resultando numa diminuição na quantidade de água drenada. Meiri et al. (1977) afirmam que a lâmina de lixiviação não deveria ser calculada com base no déficit de umidade do solo, mas sim na evapotranspiração atual da cultura, principalmente quando a irrigação é de alta frequência e sob taxas de evapotranspiração elevadas.

Segundo Hoffman et al. (1992), quando a água não é muito salina, de modo que durante o ciclo da cultura a salinidade do solo não ultrapasse a salinidade limiar, não seria necessário realizar lixiviações constantes. Neste caso, faria-se apenas uma lavagem de recuperação no final do ciclo da cultura.

Van Hoorn (1981) verificou que, em condições de campo, a equação desenvolvida por Van der Molen (1956) não estimou com precisão a lâmina de lavagem. $\mathrm{O}$ autor afirma que modelos desenvolvidos em colunas de solo em laboratório necessitam de um fator de correção para serem aplicados no campo, devido à grande variabilidade na estrutura do solo e ao fato de que parte da água de lavagem não se mistura com a solução do solo, devido à presença de grandes poros e fendas.

Hoffman (1980) recomenda usar a seguinte relação para recuperar solos salinos, com água de boa qualidade:

$$
\mathrm{L}=\mathrm{K} \cdot \mathrm{Z} \cdot \frac{\mathrm{C}_{0}}{\mathrm{C}}
$$

sendo,

$\mathrm{L}=$ lâmina de água a ser aplicada no solo para a lixiviação dos sais.

$\mathrm{K}=0,3$ a 0,1 para irrigação de recuperação por inundação em solo variando de argiloso a arenoso; ou 0,1 para aspersão ou gotejamento independendo do tipo de solo.

$\mathrm{Z}=$ profundidade do solo que deseja-se recuperar (profundidade da zona radicular).

$\mathrm{C}_{0}=$ concentração de sais na solução do solo antes da recuperação.

$\mathrm{C}=$ concentração de sais na solução do solo depois da recuperação. 
De acordo com Rhoades \& Loveday (1990), quando a água de irrigação apresenta concentração significativa de sais, sua salinidade pode entrar na equação acima, em subtração a $\mathrm{C}$ e $\mathrm{C}_{0}$, resultando em:

$$
\mathrm{L}=\mathrm{K} \cdot \mathrm{Z} \cdot \frac{\mathrm{C}_{0}-\mathrm{C}_{\mathrm{a}}}{\mathrm{C}-\mathrm{C}_{\mathrm{a}}}
$$

sendo,

$$
\mathrm{C}_{\mathrm{a}}=\text { concentração de sais da água de irrigação usada na recuperação. }
$$




\section{MATERIAL E MÉTODOS}

\subsection{Localização e características da área experimental}

O experimento foi conduzido na área experimental do Departamento de Engenharia Rural da Escola Superior de Agricultura "Luiz de Queiroz" - USP, no município de Piracicaba, SP, situado nas coordenadas geográficas de $22^{\circ} 42^{\prime}$ de latitude sul e $47^{\circ} 38^{\prime}$ de longitude oeste e altitude de $540 \mathrm{~m}$. O clima da região, na classificação climática de Köppen, é do tipo CWa, isto é, subtropical úmido, com três meses mais secos (junho, julho e agosto), chuvas de verão, seca de inverno, temperatura média do mês mais quente superior a $22^{\circ} \mathrm{C}$ e a do mês mais frio inferior a $18^{\circ} \mathrm{C}$ (Bezerra, 1995).

O solo no qual foi instalado o experimento foi descrito por Ranzani et al. (1966) como Terra Roxa Estruturada, série "Luiz de Queiroz", e pela classificação norte americana, como um Palendalf óxico, cujo material de origem são rochas básicas.

\subsection{Cultura}

A cultura utilizada foi o pepino japonês (Cucumis sativus L.), cultivar Hokushin, enxertado sobre abóbora híbrida Excite-Ikki (Cucurbita spp).

O cultivar Hokushin apresenta crescimento indeterminado, frutos de coloração verde escura brilhante, aproximadamente $20 \mathrm{~cm}$ de comprimento e diâmetro médio de 2,5-3,0 cm. O início da colheita se dá aos 40-50 dias após o transplantio (DAT) e podese prolongar o período de colheita por até 120 dias.

\subsection{Descrição das estruturas experimentais}

$\mathrm{O}$ experimento foi instalado em uma estufa de $6,30 \mathrm{~m}$ de largura, $17,50 \mathrm{~m}$ de comprimento e $2,80 \mathrm{~m}$ de pé direito. A estufa apresentava sombrite nas laterais 
e nos fundos (Figura 1). As laterais possuiam cortinas que eram abertas pela manhã e fechadas no final da tarde e na ocorrência de chuvas para evitar que a água atingisse as parcelas experimentais. Foram construídos três canteiros de $16,65 \mathrm{~m}$ de comprimento e $1 \mathrm{~m}$ de largura, que foram divididos em 9 parcelas de $1,85 \mathrm{~m}$ de comprimento e $2 \mathrm{~m}$ de largura, totalizando 27 parcelas.

O plantio foi realizado em filas duplas no espaçamento de $0,70 \mathrm{~m}$ entre linhas, 0,40 m entre as plantas úteis e 1,30 m entre as filas duplas. As parcelas experimentais foram compostas de 10 plantas e separadas transversal e lateralmente até $0,80 \mathrm{~m}$ de profundidade por uma lâmina plástica de $0,15 \mathrm{~mm}$ de espessura para evitar o deslocamento lateral de água e sais entre as parcelas (Figura 2).

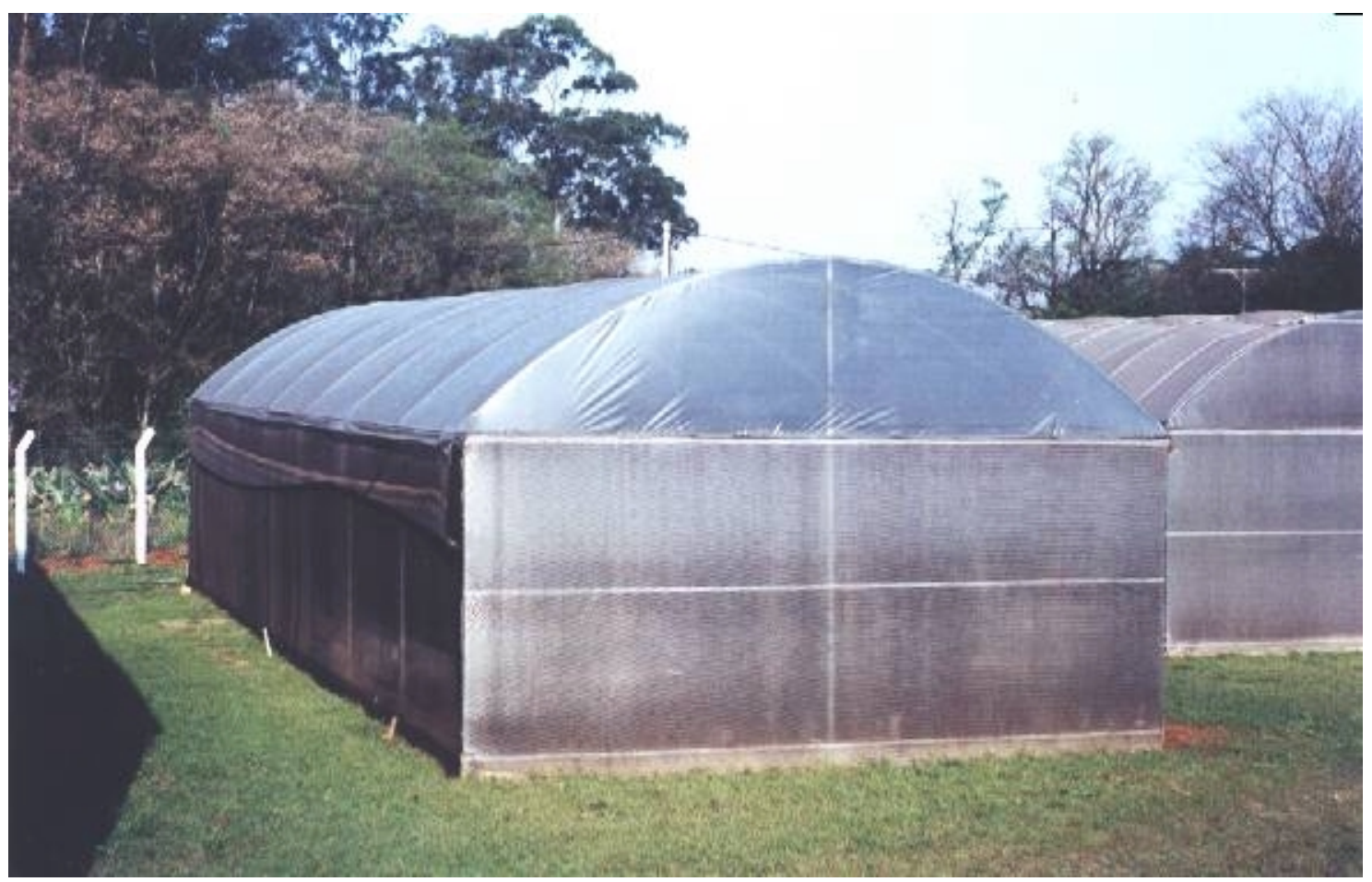

Figura 1. Estufa utilizada no desenvolvimento do experimento. 


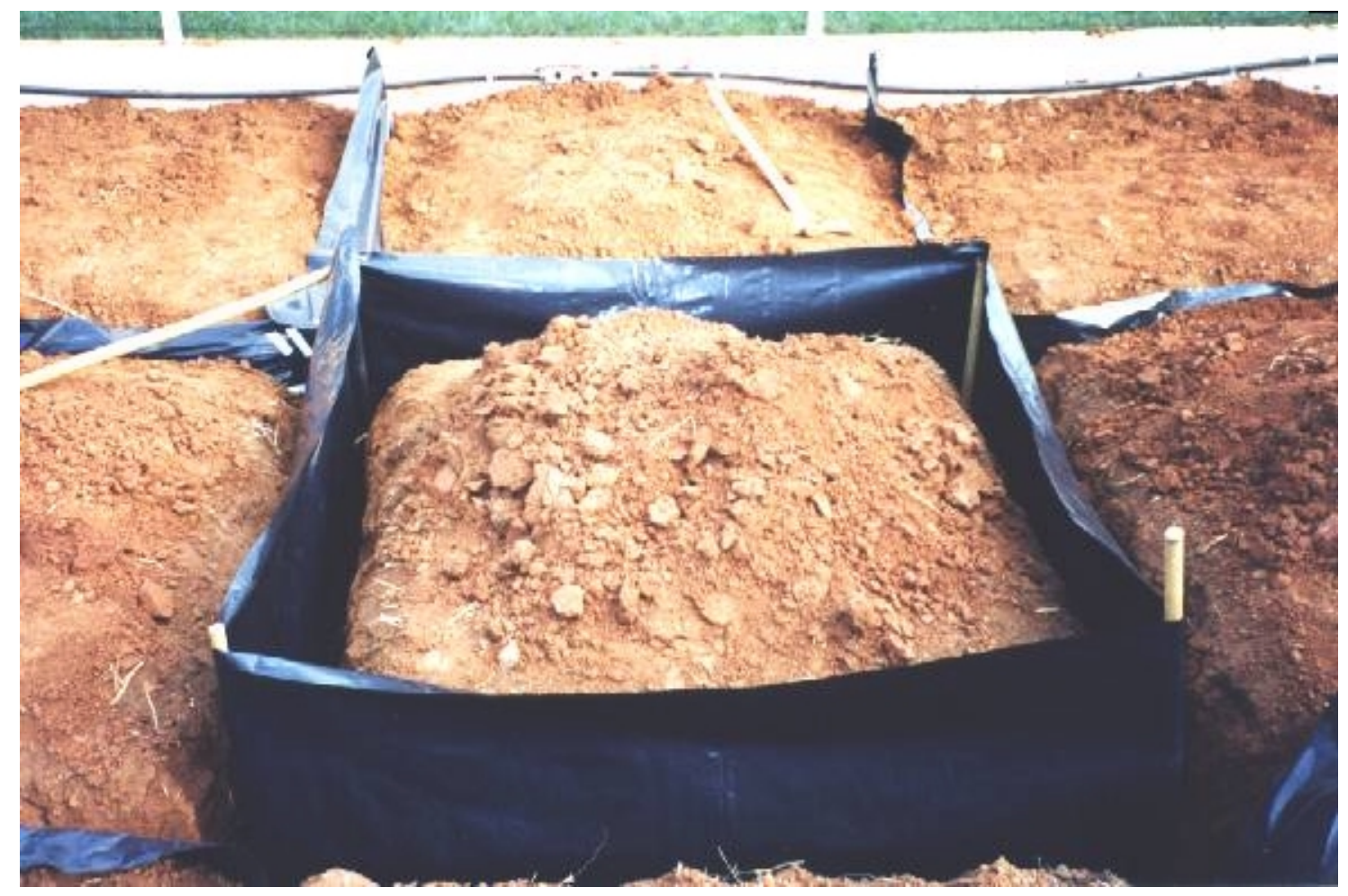

Figura 2. Isolamento das parcelas experimentais para evitar o deslocamento de sais e água para as parcelas adjacentes.

\subsection{Experimento I}

\subsubsection{Características químicas e físico-hídricas do solo}

$\mathrm{Na}$ Tabela 1 estão apresentados os resultados da análise de fertilidade, cuja amostragem foi realizada antes do transplantio das mudas. Foram coletadas duas amostras em cada parcela na profundidade de 0-30 cm, obtendo-se uma amostra composta para cada tratamento. Como o solo apresentou teores altos para todos os nutrientes e a fertilidade média do solo para os diferentes tratamentos não apresentou grandes variações, a adubação de pré-plantio não foi realizada.

Por ocasião da construção da estufa, ou seja, nove meses antes do transplantio, foram adicionados $15 \mathrm{~kg}$ de calcário dolomítico, $10 \mathrm{~kg}$ de superfosfato simples e $3,85 \mathrm{~m}^{3}$ de composto orgânico na área. Antes do cultivo do pepino, a estufa permaneceu sem cultura. 
Tabela 1. Resultados da análise de fertilidade do solo no início do período experimental.

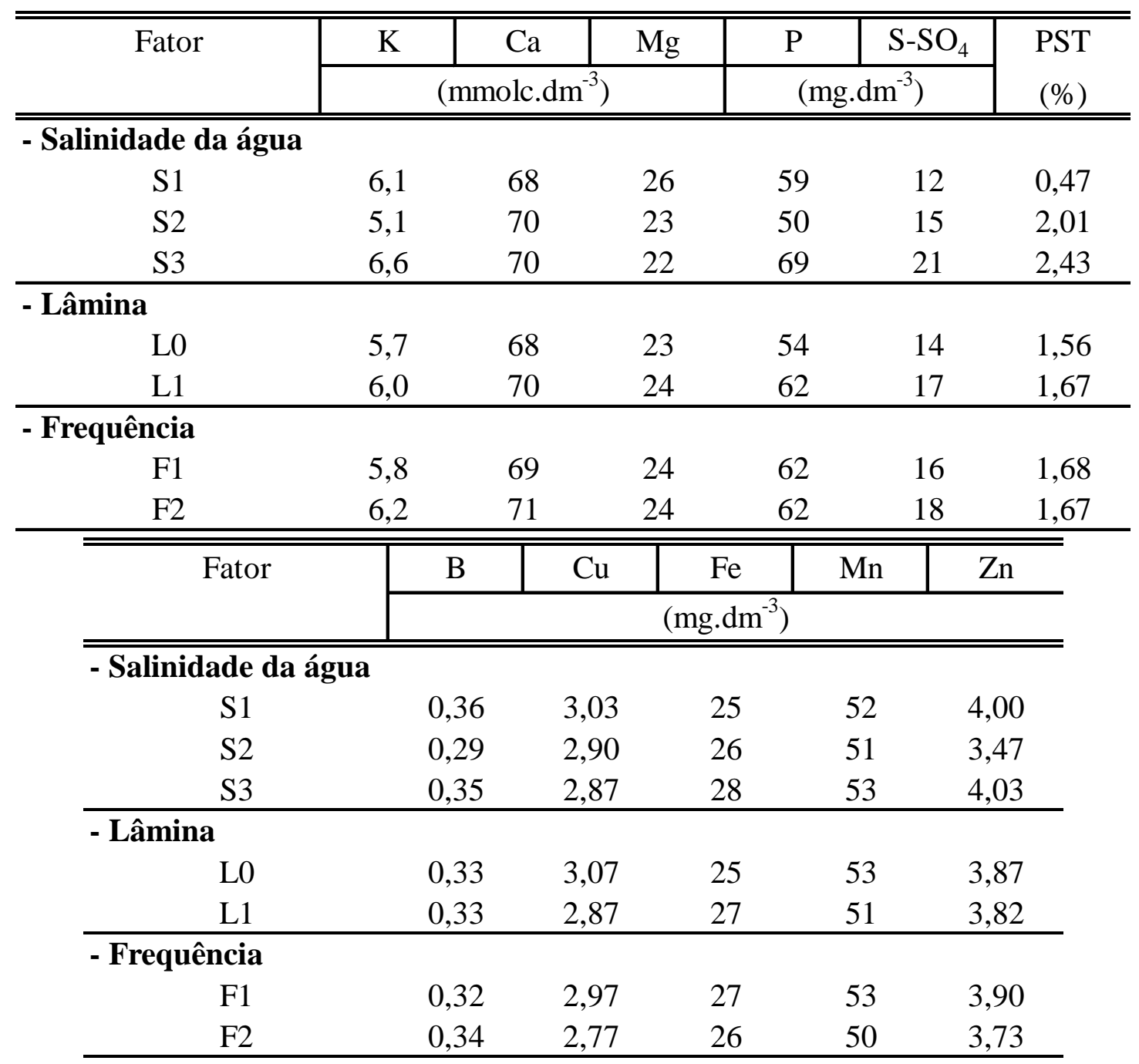

Foram coletadas amostras de solo indeformadas para a determinação da curva de retenção de água (Tabela 2) e densidade do solo nas profundidades de 0,15 e 0,30 m, obtendo-se uma amostra composta para cada bloco experimental. Também foi realizada a análise granulométrica nas profundidades 0-20, 20-40, 40-60 e 60-80 cm (Tabela 3), obtendo-se uma amostra composta para cada profundidade, representativa da área experimental.

As análises da curva de retenção de água foram realizadas na mesa de tensão para os pontos de 1, 3 e $6 \mathrm{kPa}$, e na câmara de Richards (Richards, 1948) para os pontos de $10,30,50,100,300$ e $1500 \mathrm{kPa}$. O ajuste da curva foi realizado de acordo com a 
metodologia proposta por Van Genuchten (1980), pela qual a umidade do solo pode ser descrita por:

$$
\theta(\mathrm{h})=\theta_{\mathrm{r}}+\frac{\left(\theta_{\mathrm{s}}-\theta_{\mathrm{r}}\right)}{\left[1+(\alpha \mathrm{h})^{\mathrm{n}}\right]^{\mathrm{m}}}
$$

sendo,

$\theta(\mathrm{h})$ - umidade do solo $\left(\mathrm{cm}^{-3} \cdot \mathrm{cm}^{-3}\right)$ para um dado valor de $\mathrm{h}$;

$\theta_{\mathrm{r}}-$ umidade residual do solo $\left(\mathrm{cm}^{-3} \cdot \mathrm{cm}^{-3}\right)$, obtido pelo modelo por extrapolação;

$\theta_{\mathrm{s}}$ - umidade de saturação do solo $\left(\mathrm{cm}^{-3} \cdot \mathrm{cm}^{-3}\right)$;

$\alpha, \mathrm{n}$ e m - parâmetros de ajuste do modelo;

h - módulo do potencial mátrico (cm.c.a.).

Tabela 2. Parâmetros da equação de retenção de água para cada bloco em diferentes profundidades.

\begin{tabular}{|c|c|c|c|c|c|c|c|c|}
\hline \multirow[t]{2}{*}{ Bloco } & \multirow[t]{2}{*}{ Prof. } & \multicolumn{5}{|c|}{ Parâmetros da equação de Van Genuchten (1980) } & \multirow[t]{2}{*}{$\overline{\mathrm{r}_{\mathrm{aj}}^{2}}$} & \multirow{2}{*}{$\begin{array}{c}\text { Ds } \\
\left(\mathrm{g} \cdot \mathrm{cm}^{-3}\right)\end{array}$} \\
\hline & & $\mathrm{a}$ & $\mathrm{m}$ & $\mathrm{n}$ & $\theta_{\mathrm{r}}$ & $\theta_{\mathrm{s}}$ & & \\
\hline 1 & 15 & 0,2226 & 0,1417 & 1,1651 & 0,1612 & 0,4744 & 0,98 & 1,40 \\
\hline 1 & 30 & 0,7332 & 0,0412 & 1,0430 & 0,0003 & 0,4327 & 0,99 & 1,62 \\
\hline 2 & 15 & 0,2027 & 0,1151 & 1,1301 & 0,1416 & 0,4572 & 0,99 & 1,50 \\
\hline 2 & 30 & 0,1143 & 0,1072 & 1,1201 & 0,1312 & 0,4107 & 0,98 & 1,67 \\
\hline 3 & 15 & 0,4987 & 0,0523 & 1,0552 & 0,0070 & 0,4490 & 0,99 & 1,57 \\
\hline 3 & 30 & 0,1229 & 0,0624 & 1,0665 & 0,0010 & 0,3995 & 0,98 & 1,69 \\
\hline
\end{tabular}

\subsubsection{Tratamentos e delineamento estatístico}

Os tratamentos foram compostos da combinação de 3 fatores: salinidade da água de irrigação com 3 níveis ( $\mathrm{S} 1=1,58 ; \mathrm{S} 2=3,08$ e S3 = 5,13 dS.m ${ }^{-1}$ ), lâminas de irrigação com 2 níveis ( $\mathrm{L} 0=1,00$ x ETc e L1 = 1,25 x ETc) e freqüência de aplicação da lâmina L1 com 2 níveis $(\mathrm{F} 1=$ em todas as irrigações e $\mathrm{F} 2$ = quando a lâmina de irrigação acumulada em L0 atingia 100 mm). Para a freqüência F2, as irrigações foram feitas com base na lâmina L0 e sempre que a lâmina de irrigação acumulada alcançava 100 mm, as parcelas submetidas à lâmina L1 com freqüência F2 eram complementadas 
com a lâmina que as parcelas F1 receberam. O delineamento estatístico adotado foi em blocos casualizados completos com 3 repetições e os tratamentos foram arranjados no esquema fatorial $3 \times 3$, sendo:

$\mathrm{T} 1$ = S1L0 = água S1 e lâmina de irrigação L0.

T2 = S1L1F1 = água S1 e lâmina de irrigação L1 em todas as irrigações.

$\mathrm{T} 3$ = S1L1F2 = água S1 e lâmina de irrigação L1, sendo o volume de água complementado sempre que a irrigação acumulada for de $100 \mathrm{~mm}$.

T4 = S2L0 = água S2 e lâmina de irrigação L0.

T5 = S2L1F1 = água S2 e lâmina de irrigação L1 em todas as irrigações.

T6 = S2L1F2 = água S2 e lâmina de irrigação L1, sendo o volume de água complementado sempre que a irrigação acumulada for de $100 \mathrm{~mm}$.

$\mathrm{T} 7=\mathrm{S} 3 \mathrm{~L} 0$ = água S3 e lâmina de irrigação L0.

T8 = S3L1F1 = água S3 e lâmina de irrigação L1 em todas as irrigações.

T9 = S3L1F2 = água S3 e lâmina de irrigação L1, sendo o volume de água complementado sempre que a irrigação acumulada for de $100 \mathrm{~mm}$.

Tabela 3. Granulometria e classe textural do solo em diferentes profundidades.

\begin{tabular}{c|c|c|c|c}
\hline \hline \multirow{2}{*}{ Prof. } & \multicolumn{3}{|c|}{ Granulometria (\%) } & \multirow{2}{*}{ Classe } \\
\cline { 2 - 4 } & Areia & Silte & Argila & Textural \\
\hline \hline $0-20$ & 40 & 14 & 46 & Argiloso \\
$20-40$ & 37 & 13 & 50 & Argiloso \\
$40-60$ & 35 & 13 & 52 & Argiloso \\
$60-80$ & 33 & 11 & 56 & Argiloso \\
\hline
\end{tabular}

$\mathrm{Na}$ análise estatística, a salinidade da água de irrigação foi considerada um fator quantitativo e as lâminas de irrigação, associadas ao seu manejo, foram avaliadas como fator qualitativo. Dessa forma, foi aplicado o teste de regressão para se comparar a salinidade da água, o teste de contrastes para as diferentes lâminas e o teste de Dunnett 
para comparar L1F1 e L1F2 contra L0. Na Tabela 4 encontram-se os fatores considerados nas análises, com seus respectivos graus de liberdade.

Tabela 4. Fatores considerados nas análises estatísticas, com seus respectivos graus de liberdade.

\begin{tabular}{c|c}
\hline \hline Fator & Graus de Liberdade \\
\hline \hline - Níveis de salinidade (S) & 2 \\
Linear & 1 \\
Quadr. & 1 \\
- Lâmina (L) & \\
L0 x L1F1, L1F2 & 1 \\
- Lâmina (L)/Frequência (F) & 2 \\
L0 x L1F1 x L1F2 & 4 \\
- Interação (S x LF) & \\
\hline
\end{tabular}

\subsubsection{Sistema de irrigação equipamentos para manejo da irrigação}

O sistema de irrigação utilizado foi o gotejamento, com emissores de vazão média de 4,0 $1 . \mathrm{h}^{-1}$, e um emissor por planta localizado a $2 \mathrm{~cm}$ de distância do caule. A pressurização do sistema foi realizada com uma motobomba de $0,50 \mathrm{cv}$, com vazão máxima de $401 . \mathrm{min}^{-1}$ e altura manométrica máxima de 4,0 kgf.cm ${ }^{-2}$, e mantida a $1,5 \mathrm{kgf} . \mathrm{cm}^{-2}$ durante as irrigações por um regulador de pressão, instalado no início da linha principal. Em cada parcela existia um registro para o controle da irrigação, de forma que a quantidade de água pudesse ser controlada individualmente.

Foram instalados dois tensiômetros por parcela, a 0,15 e $0,30 \mathrm{~m}$ de profundidade e a $0,10 \mathrm{~m}$ de distância do caule da planta central e um tanque de evaporação reduzido, de diâmetro 0,60 m, proposto por Medeiros et al. (1997), para o qual pode-se estimar a evaporação do tanque Classe A multiplicando a evaporação medida por uma constante, igual a 0,88 .

A Figura 3 ilustra a distribuição do sistema de irrigação e dos tratamentos na área. 


\subsubsection{Controle das irrigações}

O manejo da irrigação foi realizado tomando-se a estimativa da evapotranspiração da cultura pela evaporação do tanque. As lâminas de irrigação foram ajustadas através das leituras tensiométricas.

As irrigações foram feitas sempre que o potencial mátrico médio dos tensiômetros de 0,15 e $0,30 \mathrm{~m}$ da parcela controle (S1L0) encontrava-se entre -20 e -30 kPa. Devido à inexistência de valores de coeficiente de cultivo $(\mathrm{Kc})$ para o pepino cultivado em estufas para nossas condições, o ajuste da lâmina de irrigação foi realizado da seguinte maneira: no dia após a irrigação, verificava-se a variação do potencial mátrico dos tensiômetros instalados a 0,30 m nas parcelas controle. Caso os tensiômetros tivessem apresentado pouca variação, o Kc para a próxima irrigação era aumentado, pois a lâmina de irrigação não havia sido suficiente para elevar a umidade na camada de 0-0,30 m à capacidade de campo. Por outro lado, quando ocorriam grandes variações nas leituras tensiométricas, o Kc era reduzido na próxima irrigação a fim de evitar a lixiviação indesejada de sais abaixo da região radicular da cultura. Os valores de Kc adotados nas irrigações encontram-se na Figura 4. A estes valores foi ajustada uma equação do tipo:

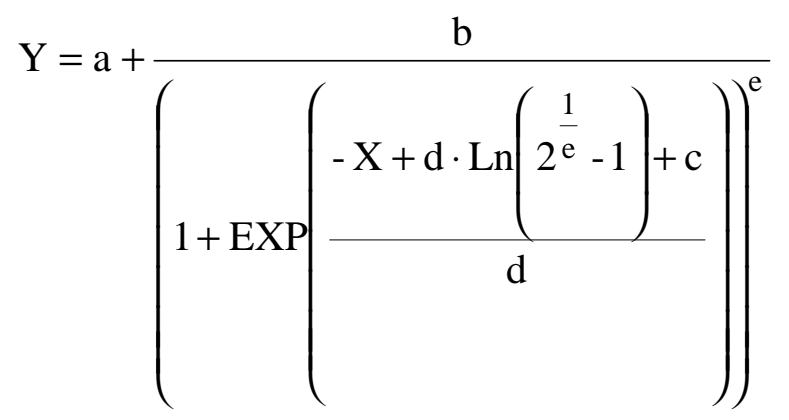

sendo,

Y - valor de Kc previsto pela equação ajustada;

a, b, c, d, e - coeficientes de ajuste da equação;

$\mathrm{X}$ - dia após o transplantio. 


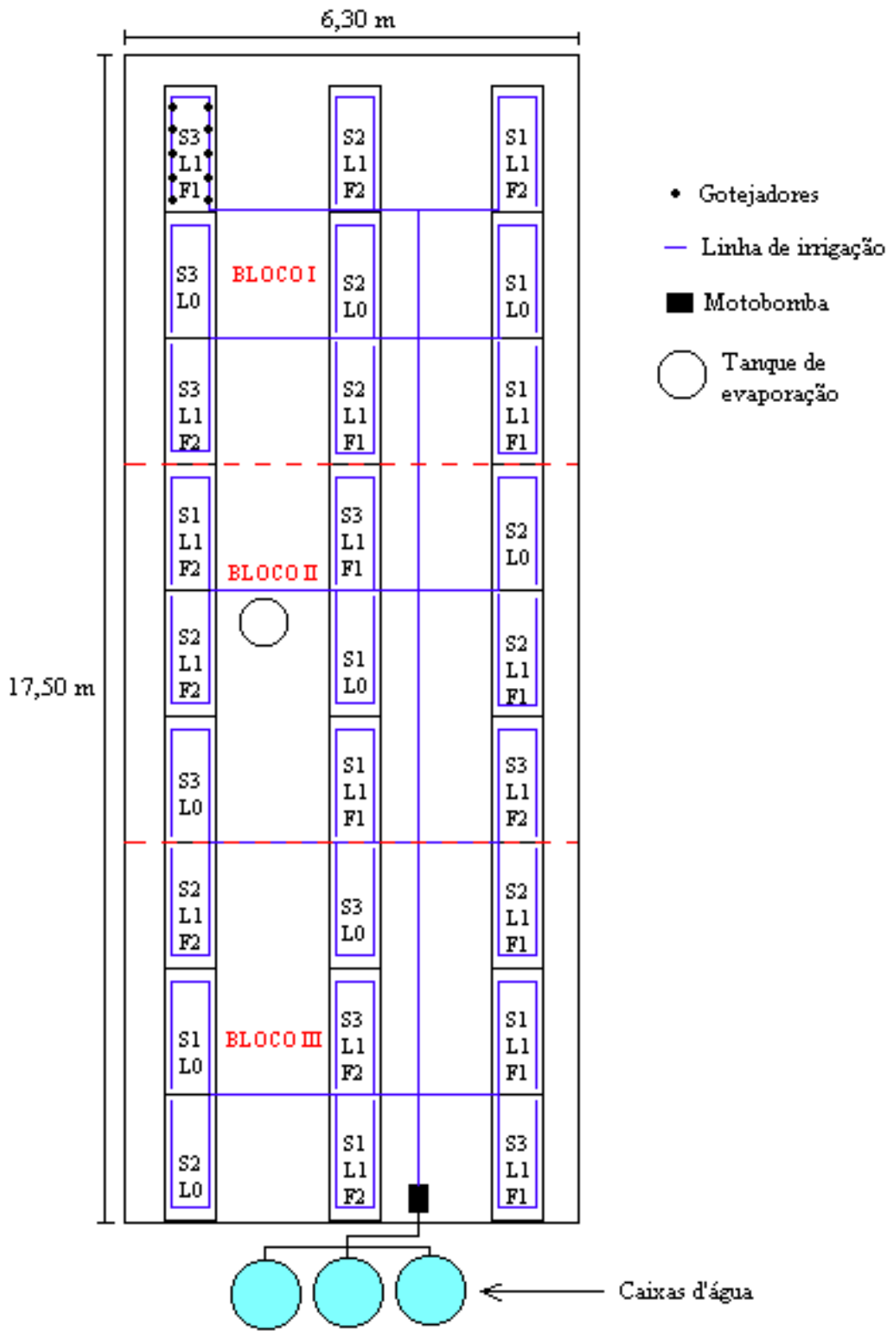

Figura 3. Croqui da área experimental e configuração do sistema de irrigação. 
O coeficiente de tanque (Kp) utilizado foi igual a 1, conforme recomendam Martínez-Raya \& Castilla (1989) e Castilla et al. (1990).

$$
\mathrm{Kc}=-0,02409487+\frac{1,54706387}{\left(1+\operatorname{EXP}\left(\frac{-\mathrm{DAT}+51,9978}{0,291312565}\right)\right)^{0,005443391}} \quad \mathrm{r}^{2}=0,85
$$

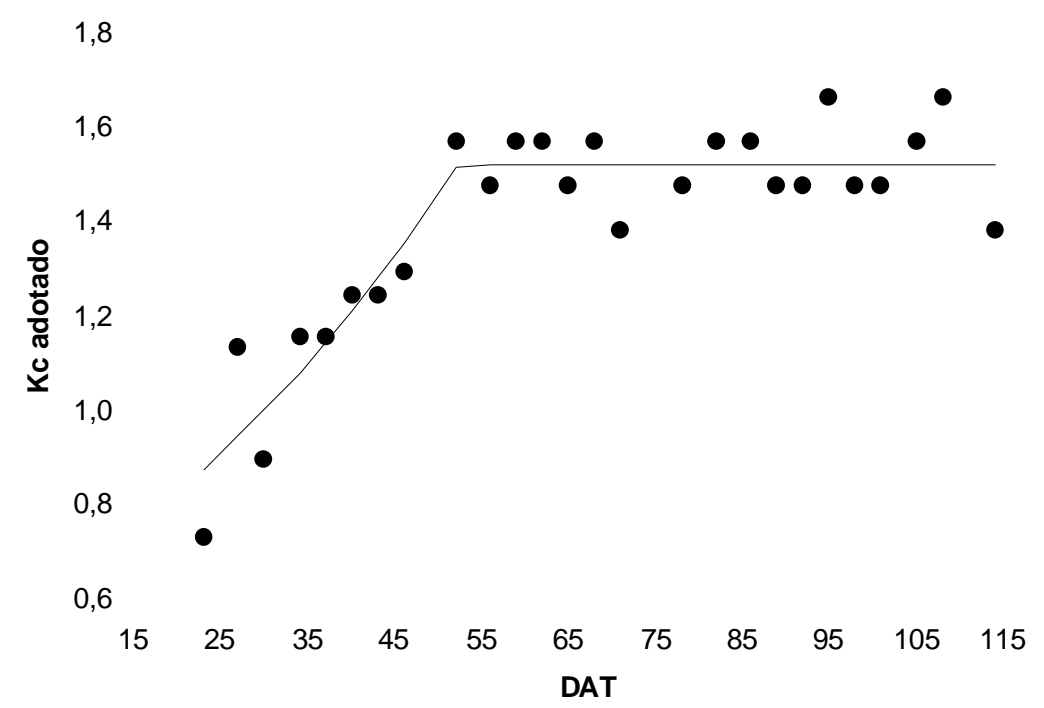

Figura 4. Valores de Kc adotados nas irrigações.

Os dados da evaporação estimada do tanque Classe A e dos coeficientes de cultivo para cada período após o transplantio encontram-se na Tabela 5. Verifica-se que o valor de Kc manteve-se praticamente estável à partir do terceiro período considerado, durante todo o período de produção da cultura. A redução na evaporação média do tanque Classe A observada até o $60^{\circ}$ dia após o transplantio é devido ao sombreamento gradativo do tanque, como consequência do crescimento das plantas. Porém, a redução na evaporação foi compensada pelo aumento do Kc e, portanto, este fato não resultou em aplicação de lâminas de irrigação menores do que a requerida pela cultura. 
Tabela 5. Evaporação média diária do tanque Classe A (ECA) no interior da estufa e valores médios do coeficiente de cultivo $(\mathrm{Kc})$ adotados nas irrigações de acordo com o período de dias após o transplantio.

\begin{tabular}{c|c|c}
\hline \hline $\begin{array}{c}\text { Dias após o } \\
\text { transplantio }\end{array}$ & $\begin{array}{c}\text { ECA } \\
\left(\mathrm{mm} . d i a^{-1}\right)\end{array}$ & Kc \\
\hline \hline $19-32$ & 2,04 & 0,92 \\
$33-46$ & 1,43 & 1,22 \\
$47-60$ & 1,13 & 1,54 \\
$61-74$ & 1,43 & 1,50 \\
$75-88$ & 1,15 & 1,54 \\
$89-102$ & 1,99 & 1,52 \\
$103-115$ & 1,83 & 1,54 \\
\hline Total $(\mathrm{mm})$ & 152 & - \\
\hline
\end{tabular}

\subsubsection{Preparo das águas de irrigação}

Diferentes adubos foram dissolvidos na água de irrigação nas proporções adequadas a fim de se obter as proporções de nutrientes exigidas pela cultura em cada fase do ciclo. Os adubos utilizados foram sulfato de amônio [ $\left.\left(\mathrm{NH}_{4}\right)_{2} \mathrm{SO}_{4}\right]$, nitrato de cálcio $\left[\mathrm{Ca}\left(\mathrm{NO}_{3}\right)_{2}\right]$, ácido fosfórico $\left(\mathrm{H}_{3} \mathrm{PO}_{4}\right)$, nitrato de potássio $\left(\mathrm{KNO}_{3}\right)$, cloreto de potássio $(\mathrm{KCl})$ e sulfato de magnésio $\left(\mathrm{MgSO}_{4} \cdot 7 \mathrm{H}_{2} \mathrm{O}\right)$, sendo que todos os tratamentos receberam $1 / 4$ do $\mathrm{N}$ na forma de amônio e $3 / 4$ na forma de nitrato.

Para as águas S2 e S3, além dos adubos, foram ainda adicionados os sais cloreto de sódio $(\mathrm{NaCl})$, cloreto de cálcio $\left(\mathrm{CaCl}_{2}\right)$ e sulfato de magnésio, em proporções adequadas para cada nível de salinidade, de modo que a relação $(\mathrm{Na}+\mathrm{K}): \mathrm{Ca}: \mathrm{Mg}$ fosse de 3:2:1. Portanto, a quantidade dos adubos $\mathrm{KNO}_{3}$ e $\mathrm{KCl}, \mathrm{Ca}\left(\mathrm{NO}_{3}\right)_{2}$ e $\left(\mathrm{NH}_{4}\right)_{2} \mathrm{SO}_{4}$ adicionados às águas para suprir a demanda de nutrientes pela cultura substituíam, respectivamente, partes dos sais $\mathrm{NaCl}, \mathrm{CaCl}_{2}$ e $\mathrm{MgSO}_{4} \cdot 7 \mathrm{H}_{2} \mathrm{O}$.

A água utilizada nas irrigações tinha condutividade elétrica de $0,22 \mathrm{dS} \cdot \mathrm{m}^{-1} \mathrm{e}$ pH 8,1, possuindo a seguinte composição química: $\mathrm{Na}=0,24 ; \mathrm{Ca}=0,69 ; \mathrm{Mg}=0,45$; $\mathrm{K}=0,07 ; \mathrm{Cl}=0,01 ; \mathrm{SO}_{4}=0,48$ e alcalinidade $\left(2 \mathrm{CO}_{3}{ }^{-2}+\mathrm{HCO}_{3}{ }^{-}\right)=0,34 \mathrm{mmol}_{\mathrm{c}} \cdot \mathrm{l}^{-1}$.

As quantidades de nitrogênio, fósforo e potássio aplicadas durante o ciclo da cultura foram obtidas em Vivancos (1993), em função da produtividade esperada, que

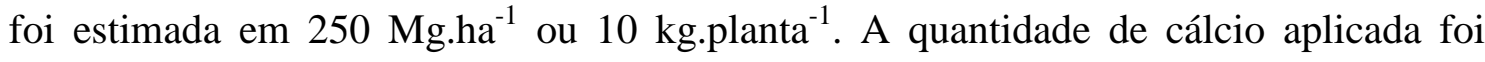


fixada em $70 \%$ da quantidade de $\mathrm{N}$, e de magnésio em 0,61 g.planta ${ }^{-1}$. O parcelamento dos adubos durante o ciclo da cultura foi aquele recomendado por Papadopoulos (1994) (Tabela 6). A concentração de adubos na água foi determinada pela quantidade de fertilizantes a serem aplicados em cada período e pela estimativa do volume de água a ser aplicado, baseado na estimativa da evaporação do tanque no interior da estufa.

Tabela 6. Quantidades e parcelamento de nutrientes a serem aplicados durante o ciclo de cultivo.

\begin{tabular}{|c|c|c|c|c|c|}
\hline \multirow[t]{2}{*}{ Semana } & $\overline{\mathrm{N}}$ & $\bar{P}$ & $\overline{\mathrm{K}}$ & $\mathrm{Ca}$ & $\overline{\mathrm{Mg}}$ \\
\hline & \multicolumn{5}{|c|}{$\mathrm{g}$} \\
\hline$\overline{1} 1^{\mathrm{a}}$ & $\overline{17,2}$ & $\overline{1116,2}$ & $\overline{74,4}$ & $\overline{447,6}$ & $\overline{1,4}$ \\
\hline $2^{\underline{a}}$ & 54,5 & 34,9 & 89,7 & 95,2 & 2,7 \\
\hline $3^{\mathrm{a}}$ & 84,8 & 43,6 & 148,3 & 83,3 & 3,4 \\
\hline $4^{\underline{a}}$ & 113,1 & 52,3 & 177,9 & 100,0 & 4,1 \\
\hline $5^{\mathrm{a}}-12^{\mathrm{a}}$ & 357,4 & 130,7 & 480,9 & 250,0 & 13,5 \\
\hline $13^{a}-17^{a}$ & 238,3 & 87,1 & 320,6 & 166,6 & 9,0 \\
\hline g/estufa & 4320,0 & 1728,0 & 5940,0 & 3159,0 & 164,7 \\
\hline g/planta & 16,0 & 6,4 & 22,0 & 11,7 & 0,6 \\
\hline
\end{tabular}

No período compreendido entre a $5^{\mathrm{a}}$ e $12^{\mathrm{a}}$ semana, a estimativa da quantidade de água a ser aplicada ficou muito acima da real (Figura 5). Como a quantidade de adubos e a quantidade de água aplicada são proporcionais, houve uma redução no fornecimento de nutrientes neste período. Porém, como as plantas apresentavam-se sem sintomas de deficiência, os níveis de adubação não foram alterados, resultando numa aplicação de 11,4, 4,2, 15,7, 8,2 e 0,43 g.planta ${ }^{-1}$ de N, P, K, Ca e Mg, respectivamente, durante o ciclo da cultura. A quantidade aplicada de cada fertilizante nas irrigações estão apresentadas no Apêndice 1. 


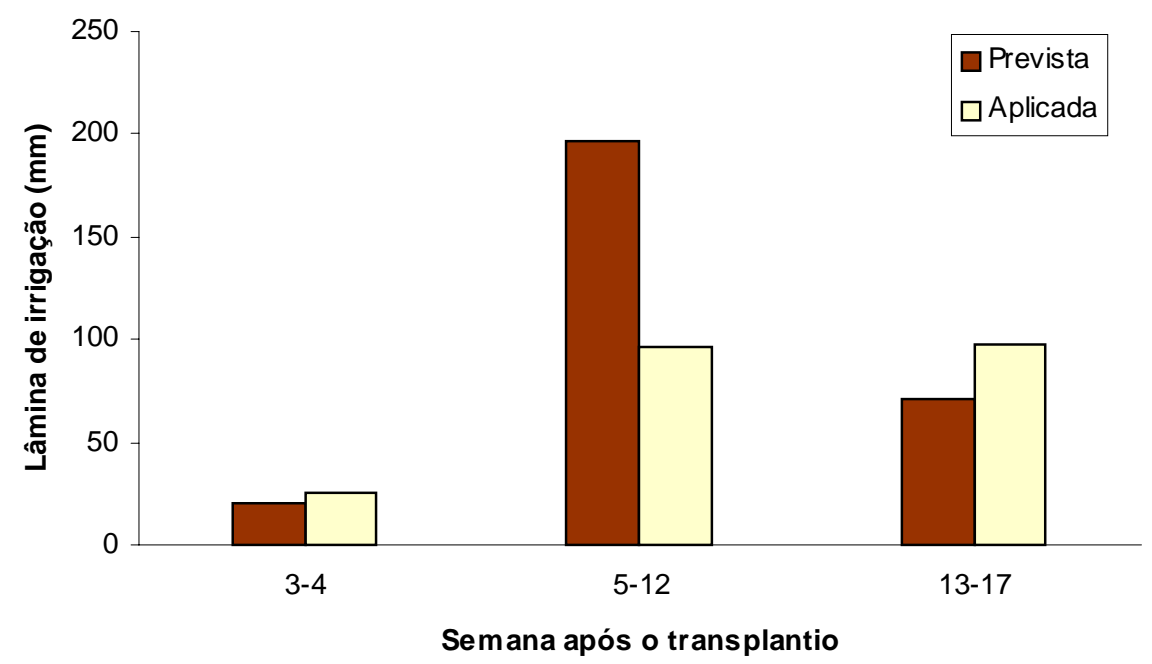

Figura 5. Lâmina de irrigação prevista e aplicada em função do intervalo de semanas após o transplantio.

\subsubsection{Condução da cultura}

As plantas foram conduzidas em haste única e tutoradas por um fitilho, o qual era preso em um fio de arame instalado a 1,90 m de altura em relação à superfície do canteiro. $\mathrm{O}$ fio de arame foi escorado por sarrafos de madeira, colocados nas divisões entre duas parcelas, ou seja, a cada $1,85 \mathrm{~m}$.

Aos 30 DAT foram retirados todos os frutos e folhas localizados até o quinto

nó da planta. À partir do sexto nó, permitiu-se o desenvolvimento de uma ramificação por nó, sendo que os ponteiros destas ramificações foram cortados à partir da terceira folha. Todos os frutos que surgiram à partir do sexto nó da planta foram deixados, independente do número de frutos que se desenvolveu em cada nó.

Os tratos fitossanitários consistiram na aplicação de fungicidas à base de cobre e mancozeb. Por ocasião do aparecimento de sintomas de oídio, também realizou-se uma pulverização de fungicida à base de enxofre na metade da concentração recomendada, visto que as cucurbitáceas são muito sensíveis ao enxofre sob condições de temperaturas altas. Também foram aplicados, semanalmente, inseticidas para controle de pulgão e mosca branca, os quais são vetores dos vírus do mosaico e viracabeça das cucurbitáceas. 
As colheitas iniciaram-se aos 33 DAT e foram realizadas em intervalos de 1 a 3 dias, dependendo do tempo necessário para que os frutos atingissem o ponto de colheita, que é de, aproximadamente, $20 \mathrm{~cm}$ de comprimento, totalizando 37 colheitas durante o ciclo da cultura.

\subsubsection{Parâmetros avaliados}

\subsubsection{Planta}

Um esquema detalhado da parcela experimental pode ser visto na Figura 6. A área útil da parcela foi representada apenas pelas 6 plantas centrais, eliminando-se, portanto, as plantas que ficavam localizadas nas extremidades, tendo sido avaliados os seguintes parâmetros:

a) Altura, diâmetro do colo e área foliar das plantas, tomadas em intervalos de 15 a 20 dias. Para isto, foram utilizadas apenas as plantas 2 e 5 de cada parcela.

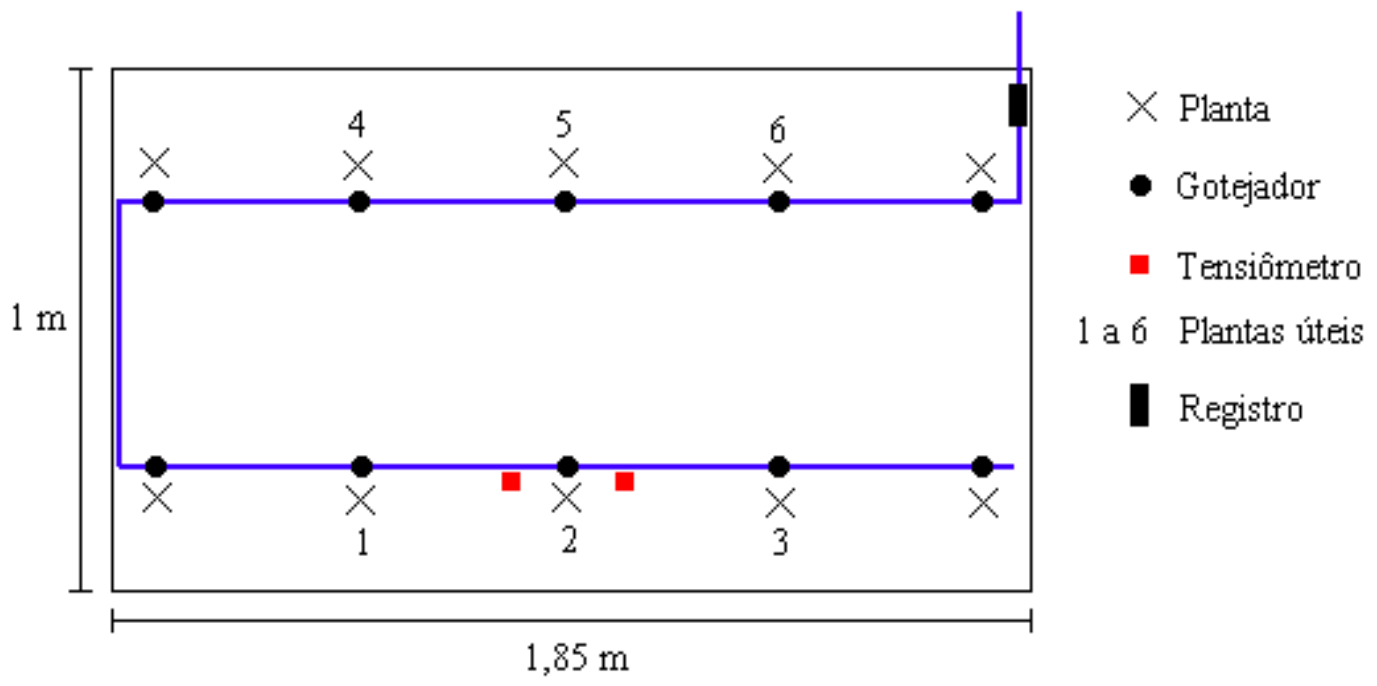

Figura 6. Esquema de uma parcela experimental, indicando as posições dos tensiômetros e plantas úteis.

A altura das plantas foi medida com uma trena e foi tomada a distância entre a superfície do solo e o ponteiro da planta. O diâmetro do colo foi medido com um paquímetro, de precisão de $0,05 \mathrm{~mm}$, sendo o caule das plantas medido a $1 \mathrm{~cm}$ de altura em relação ao solo, abaixo do ponto de enxertia. 
Para a medição da área foliar, foi utilizada uma planta de cada tratamento e medidas a sua altura, a altura de inserção da folha no caule e o comprimento e largura de todas as folhas da planta. Para se estabelecer a relação entre a área foliar e as medidas de comprimento e largura da folha, 8 folhas de diferentes tamanhos foram coletadas em cada tratamento. O comprimento e a largura destas folhas foram medidos e a área foliar de cada uma delas foi determinada através de um medidor digital de área foliar. Pela Figura 7, observa-se alta correlação entre a área foliar e as medidas de comprimento e largura para todas as salinidades da água de irrigação. Com isso, pôde-se determinar o padrão de distribuição de área foliar das plantas e definir a localização da folha que representasse a área foliar média da planta, a qual foi determinada pela altura relativa da folha em relação à planta. Pelos Apêndices 2 e 3, verifica-se que ocorreu uma relação entre a altura da planta e a área foliar e, portanto, pôde-se determinar a área foliar média da planta apenas com a medição da folha que a representa. Para se determinar a posição exata da folha a ser medida, tomou-se as equações de regressão das plantas irrigadas com a mesma água e determinou-se a área foliar média para cada altura relativa, em intervalos de 5\% (Apêndice 4). Para as medições realizadas aos 35 DAT foram utilizados os dados médios das nove plantas medidas, uma vez que o período ao qual as plantas vinham sendo submetidas às irrigações salinas ainda era pequeno e o padrão de distribuição da área foliar foi semelhante entre os tratamentos.

A área foliar foi determinada aos 34, 55 e 63 DAT, sendo que o padrão de distribuição de área foliar (PDAF) determinado para medição aos 55 DAT também foi utilizado aos 63 DAT. Após esta fase, a determinação do PDAF tornou-se impraticável devido à dificuldade em sua determinação, resultado do grande número de folhas e ramificações. No final do período experimental (115 DAT), a área foliar das plantas utilizadas na determinação do PDAF foi medida, assim como a matéria seca das folhas. b) Produção e número de frutos por planta, comercial e total. Foram considerados frutos não comerciais apenas os frutos excessivamente tortos e mau formados (Figura 8). 


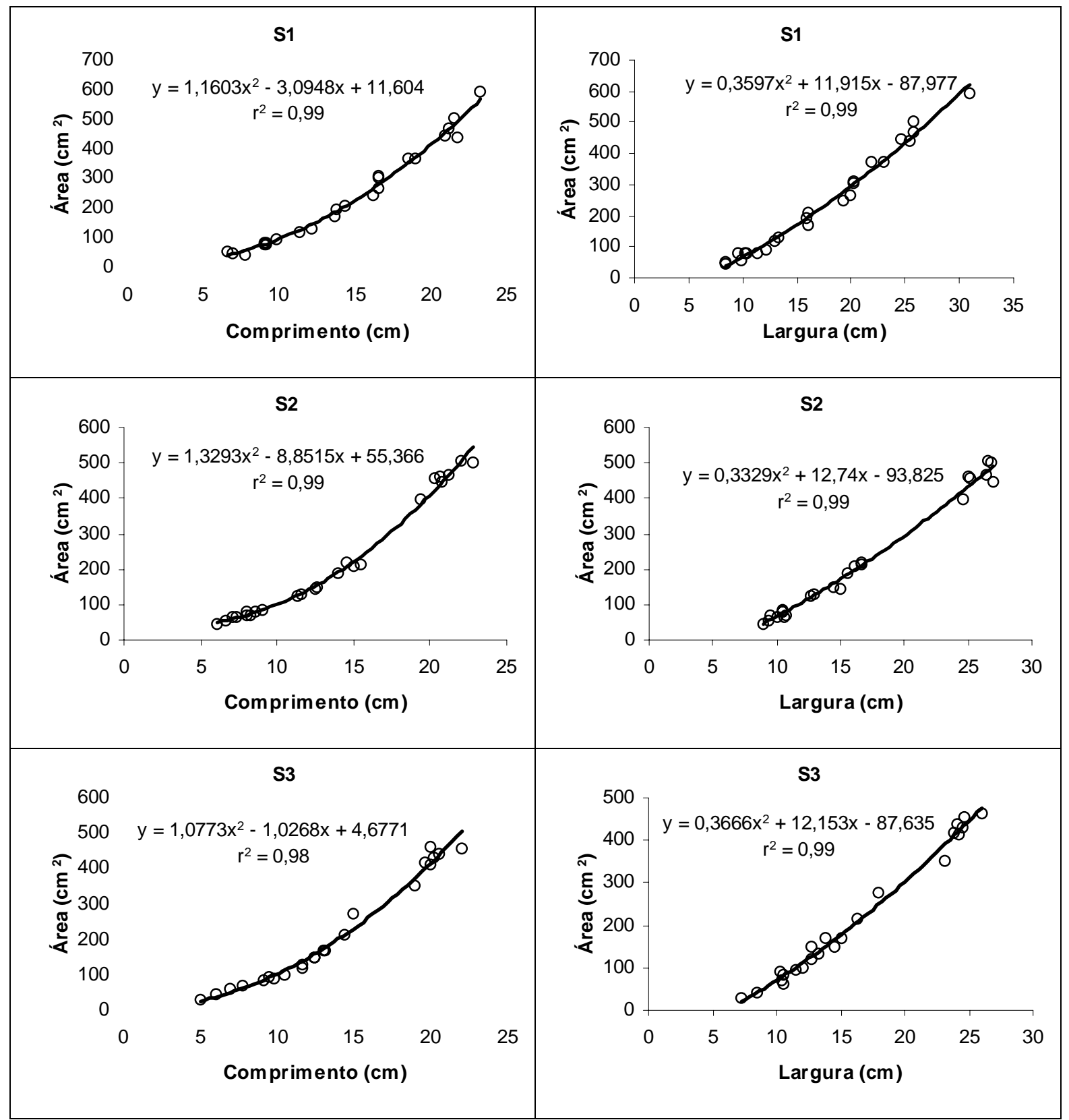

Figura 7. Relação entre o comprimento e a largura da folha e a área foliar.

c) Concentração de macro e micronutrientes e $\mathrm{Na}$ nas folhas e nos frutos. No final do período produtivo, foram coletadas amostras da terceira folha, à partir do ápice da planta, e de frutos para análise química. As amostras de um mesmo tratamento foram coletadas em todas as parcelas, formando uma amostra composta para cada tratamento. d) Peso médio dos frutos comerciais. 
e) Comprimento, diâmetro, relação comprimento/diâmetro e porcentagem de matéria seca de 3 frutos comerciais por parcela, realizadas quinzenalmente. $\mathrm{Na}$ análise estatística, a porcentagem de matéria seca foi analisada utilizando-se a transformação $\sqrt{\mathrm{x}+0,5}$, conforme recomendam Steel \& Torrie (1980), sendo $\mathrm{x}$ a porcentagem de matéria seca dos frutos.

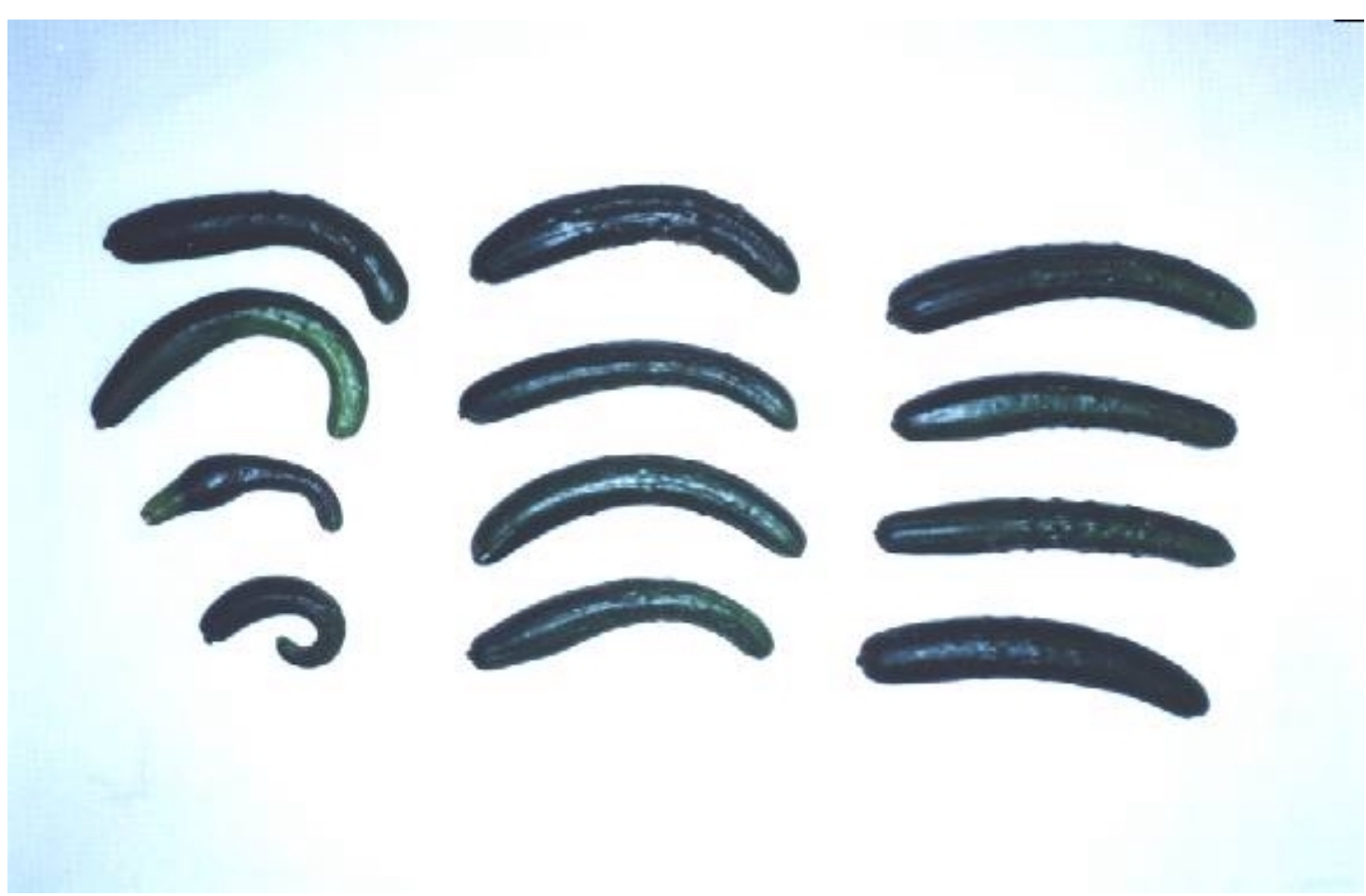

Figura 8. Frutos de pepino, demonstrando frutos comerciais (primeira e segunda colunas) e frutos não comerciais (terceira coluna).

\subsubsection{Solo}

a) Salinidade do solo nas profundidades 0-20, 20-40 e 40-60 cm, sendo determinada no início e no final do ciclo da cultura e a cada 100 mm de lâmina de irrigação acumulada, ou seja, após a aplicação da lâmina L1 nos tratamentos de frequência F2. Como a lâmina total de irrigação durante o ciclo da cultura foi 194 mm, apenas uma aplicação da lâmina L1 em F2 foi realizada, a qual ocorreu aos 75 DAT. Nestes tratamentos, a amostragem também foi realizada antes da aplicação da lâmina L1 para determinação da 
salinidade média do solo neste período. Nas amostragens inicial e final, também foi determinada a salinidade na camada $60-80 \mathrm{~cm}$.

$\mathrm{Na}$ primeira e na última amostragens, as amostras foram coletadas em 4 pontos preestabelecidos em cada parcela, sendo dois à $5 \mathrm{~cm}$ do gotejador, entre as filas de plantas, e outros dois à $10 \mathrm{~cm}$ do colo da planta, entre 2 plantas na linha de plantio. $\mathrm{Na}$ segunda amostragem, as amostras foram coletadas em apenas um ponto de cada posição relativa.

As análises da condutividade elétrica do solo foram realizadas pelo método da $\mathrm{CE}_{1: 2}$, que consiste na medida da condutividade elétrica do sobrenadante de uma solução preparada com uma parte de solo (terra fina seca ao ar) para duas de água destilada, em base peso. Em algumas amostras também foi determinada a condutividade elétrica do extrato de saturação (CEes), que é a medida padrão para a análise de resposta das culturas à salinidade do solo. Com a obtenção de uma curva de regressão correlacionando a $\mathrm{CE}_{1: 2}$ e a CEes, a CEes foi estimada para todas as amostras à partir dos valores medidos da $\mathrm{CE}_{1: 2}$.

Devido à adição de grande quantidade de matéria orgânica no solo, determinou-se a relação entre a CEes e $\mathrm{CE}_{1: 2}$ para a camada de 0-20 e 20-40 cm, sendo que esta última também foi utilizada para estimar a CEes para as camadas de 40-60 e 60-80 cm (Apêndice 5).

b) Potencial mátrico médio e salinidade média na região radicular ao longo do ciclo da cultura. As leituras dos tensiômetros foram realizadas diariamente entre 7:00 e 8:30 hs e foram obtidas as médias dos potenciais para as parcelas submetidas ao mesmo tratamento. No Apêndice 6 são mostrados os valores do módulo do potencial mátrico médio para as profundidades de 15 e $30 \mathrm{~cm}$ em cada tratamento.

A salinidade média foi obtida pela média das três amostragens realizadas durante o ciclo da cultura, utilizando-se a média das amostras de 0-20 e 20-40 cm, uma vez que a profundidade efetiva do sistema radicular foi considerada como sendo de 0,30 m. Para as parcelas submetidas à frequência F2 de aplicação da lâmina L1, a salinidade média foi obtida pela expressão: 


$$
\mathrm{C}=\frac{\mathrm{c}_{2}-\mathrm{c}_{1}+\mathrm{c}_{4}-\mathrm{c}_{3}}{4}
$$

sendo,

C - Salinidade média do solo durante o ciclo da cultura;

$c_{2}$ - salinidade do solo antes da aplicação de L1;

$\mathrm{c}_{1}$ - salinidade inicial do solo;

$\mathrm{c}_{4}$ - salinidade final do solo;

$c_{3}$ - salinidade do solo após a aplicação de L1.

\subsection{Experimento II}

Encerrado o cultivo do pepino, foi realizado o trabalho de recuperação do solo através da aplicação de diferentes lâminas de lavagem. Os tratamentos foram os seguintes:

a) Método de aplicação das lâminas: gotejamento e inundação.

b) Lâminas de lavagem: $\mathrm{D}_{1}=\frac{2 \cdot \mathrm{L}}{3} ; \mathrm{D}_{2}=\mathrm{L}$ e $\mathrm{D}_{3}=\frac{3 \cdot \mathrm{L}}{2}$, onde $\mathrm{L}$ é a lâmina calculada pela equação proposta por Rhoades \& Loveday (1990), assumindo $\mathrm{K}=0,1$ para gotejamento e 0,2 para inundação, $\mathrm{Z}=0,60 \mathrm{~m}, \mathrm{C}=1,5 \mathrm{dS} \cdot \mathrm{m}^{-1}$ e $\mathrm{C}_{\mathrm{a}}=0,22 \mathrm{dS} \cdot \mathrm{m}^{-1}$.

O delineamento experimental foi em blocos ao acaso e arranjados no esquema fatorial 2 x 3, sendo os fatores a lâmina de lavagem com 3 níveis $\left(D_{1}, D_{2}\right.$ e $\left.D_{3}\right)$ e o método de aplicação da lâmina (inundação e gotejamento).

Durante a aplição das lâminas, as parcelas foram mantidas cobertas com plástico para minimizar as perdas de água por evaporação e permaneceram cobertas durante 10 dias para que o excesso de água fosse drenado e o solo se mantivesse com a umidade na capacidade de campo. Após este período, o solo foi amostrado nas profundidades de $0-20,20-40,40-60 \mathrm{~cm}$, em pontos próximos àqueles utilizados na amostragem antes da recuperação, para avaliar a eficiência da lavagem.

Os seguintes parâmetros foram avaliados:

a) Salinidade média final na camada de 0-60 cm após a recuperação.

b) Redução da salinidade do solo promovida pela lixiviação 
c) Relação entre a salinidade depois e antes da recuperação, a qual representa a fração da concentração inicial de sais que permanece no solo após a aplicação da lâmina de lixiviação.

d) Coeficiente k, estimado utilizando os dados de salinidade do solo após a recuperação, pela equação de Rhoades \& Loveday (1990) 


\section{RESULTADOS E DISCUSSÃO}

\subsection{Experimento I}

\subsubsection{Desenvolvimento vegetativo das plantas}

\subsubsection{Altura das plantas}

Fisiologicamente, o crescimento da planta é medido em termos de matéria seca acumulada ao longo do tempo, representando a fotossíntese líquida. Entretanto, devido à existência de correlação entre a altura e o peso da planta, é comum se avaliar o crescimento de uma planta através de sua altura (Medeiros, 1998).

O crescimento das plantas de pepino está apresentado na Figura 9, para cada nível de salinidade da água, lâmina de irrigação e frequência de aplicação da lâmina L1. Observa-se que o crescimento das plantas foi contínuo até o $63^{\circ}$ DAT, sendo que à partir desta data o crescimento foi mais lento. Após o 35ํㅡㄴ DAT as curvas de crescimento para as diferentes salinidades da água começaram a se distanciar e permaneceram com diferença praticamente constante após o $63^{\circ}$ DAT, com diferenças variando de 4,5 a $7,5 \%$ para a água $\mathrm{S} 2$ e 5,0 a $8,7 \%$ para a água $\mathrm{S} 3$, em relação à água $\mathrm{S} 1$. Para as diferentes lâminas de irrigação, a altura das plantas foi praticamente igual em todas as medições. Nas medições realizadas antes do $35^{\circ}$ e após o $79^{\circ}$ DAT, as alturas foram semelhantes entre as diferentes frequências de aplicação da lâmina L1. Porém, no período compreendido entre este intervalo de tempo, as diferenças variaram de 7,0 a $7,5 \%$, com vantagem para F2. 


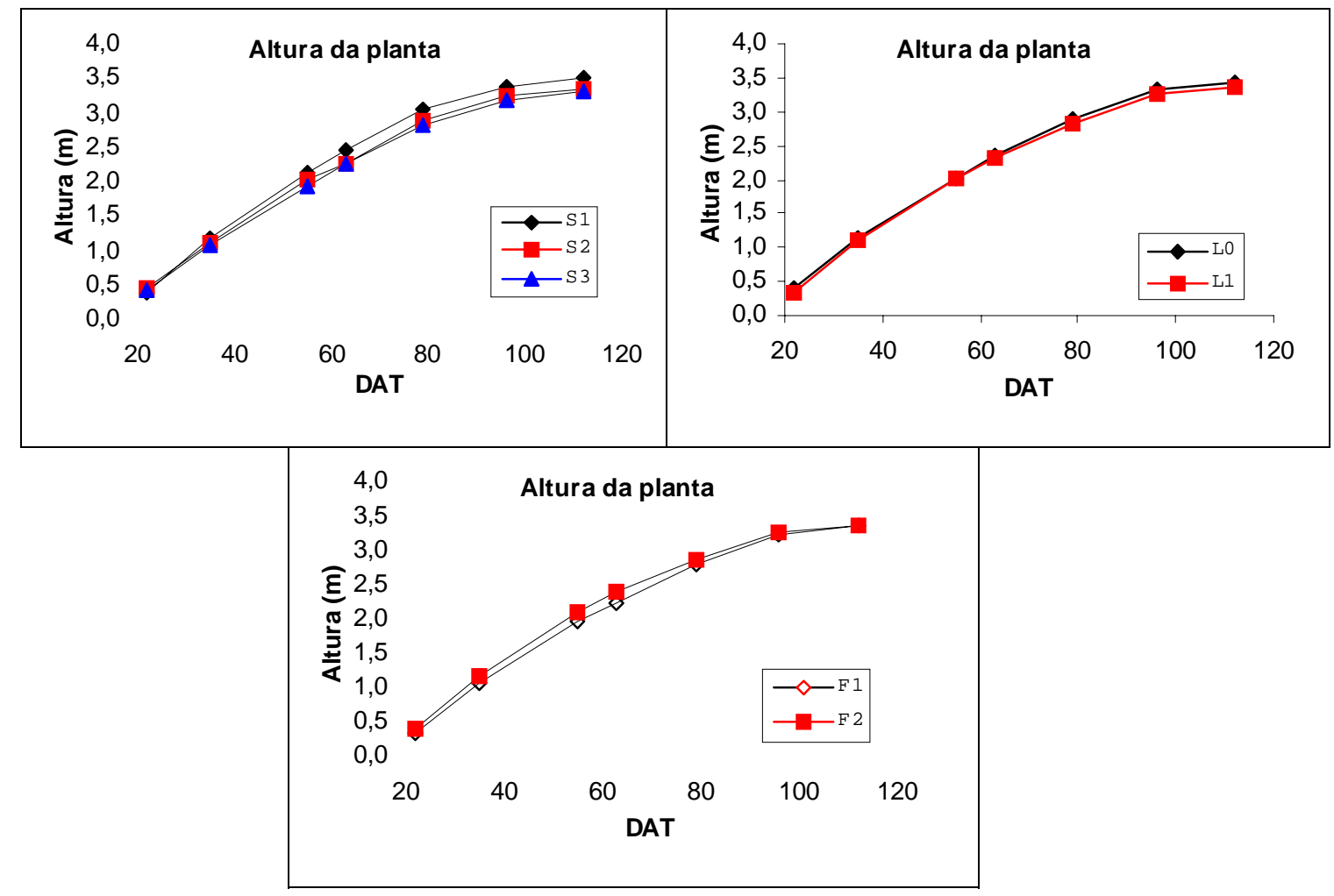

Figura 9. Crescimento das plantas de pepino para cada salinidade da água, lâmina de irrigação e frequência de aplicação da lâmina L1.

Pela Tabela 7, verifica-se que a altura das plantas foi afetada linearmente pela salinidade da água de irrigação nas quatro medições avaliadas, sendo que as lâminas de irrigação e a frequência de aplicação de L1 não resultaram em diferenças estatisticamente significativas. A altura foi maior para a lâmina L0, com exceção da medição realizada aos 55 DAT, e para a frequência F2, exceto aos 112 DAT, quando a frequência F1 superou F2. 
Tabela 7. Resumo da ANAVA para a altura das plantas em quatro épocas distintas, para as diferentes salinidades da água, lâminas de irrigação e frequências de aplicação da lâmina L1.

\begin{tabular}{|c|c|c|c|c|}
\hline \multirow{3}{*}{ Fator } & \multicolumn{4}{|c|}{ Estatística F } \\
\hline & \multicolumn{4}{|c|}{ Altura das plantas (m) } \\
\hline & 55 & 63 & 96 & 112 \\
\hline - Níveis de salinidade (S) & 3,17 & $5,37 *$ & 3,00 & 3,30 \\
\hline Linear & $6,24 *$ & $8,08^{*}$ & $5,25^{*}$ & $4,97 *$ \\
\hline Quadr. & 0,11 & 2,67 & 0,75 & 1,63 \\
\hline - Lâmina (L) & 0,01 & 0,21 & 0,96 & 1,13 \\
\hline - Lâmina (L)/Frequência (F) & 1,89 & 3,48 & 0,51 & 0,63 \\
\hline \multirow[t]{2}{*}{ - Interação (S x LF) } & 0,47 & 1,62 & 1,12 & 0,90 \\
\hline & \multicolumn{4}{|c|}{ Valores médios } \\
\hline \multicolumn{5}{|l|}{ - Níveis de salinidade } \\
\hline S1 & 2,13 & 2,45 & 3,37 & 3,50 \\
\hline S2 & 2,03 & 2,27 & 3,24 & 3,35 \\
\hline S3 & 1,94 & 2,25 & 3,19 & 3,33 \\
\hline \multicolumn{5}{|l|}{ - Lâmina (L) } \\
\hline L0 & 2,03 & 2,34 & 3,31 & 3,44 \\
\hline L1 & 2,03 & 2,31 & 3,25 & 3,37 \\
\hline \multicolumn{5}{|l|}{ - Lâmina (L)/Frequência (F) } \\
\hline L1F1 & 1,93 & 2,22 & 3,24 & 3,38 \\
\hline L1F2 & 2,11 & 2,40 & 3,26 & 3,35 \\
\hline
\end{tabular}

* Significativo ao nível de 0,05 de probabilidade pelo teste $\mathrm{F}$

\subsubsection{Diâmetro do colo}

Verifica-se pela Figura 10 que o diâmetro do colo (DC) das plantas teve aumento constante até o $55^{\circ}$ DAT, sendo que após o $63^{\circ}$ DAT o ritmo de crescimento reduziu consideravelmente. Para a água S3 o DC foi sempre inferior às demais, enquanto que S2 superou S1 durante todo o período de cultivo. As curvas de crescimento do DC para as diferentes lâminas de irrigação foram bastante semelhantes, tanto em comportamento quanto em magnitude. Já para as diferentes frequências de aplicação da lâmina L1, F2 superou F1 durante todo o período, sendo que a diferença aumentou do início do período até o $55^{\circ}$ DAT, à partir do qual manteve-se praticamente constante. 


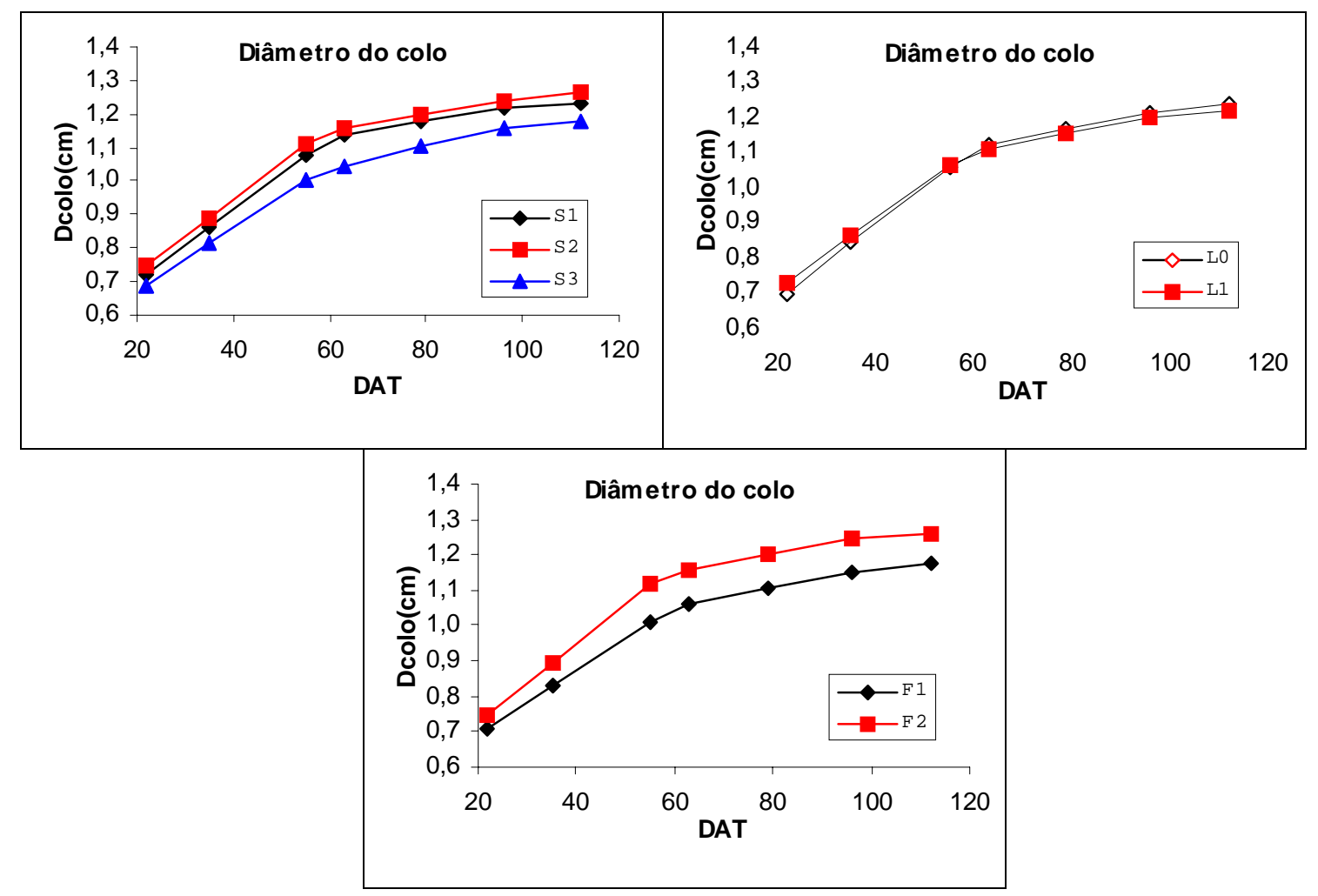

Figura 10. Diâmetro do colo das plantas de pepino para cada salinidade da água, lâmina de irrigação e frequência de aplicação da lâmina L1.

A análise estatística, apresentada na Tabela 8 , revelou que houve redução linear do DC com o aumento da salinidade da água de irrigação para as medições realizadas aos 55 e 63 DAT. Como S2 superou S1 durante todo o ciclo da cultura, realizou-se o teste de Tukey para comparar as médias do DC para as diferentes salinidades da água, o qual revelou haver diferença significativa para S2 e S3, sendo que S1 não diferiu das demais, indicando que apenas o maior nível de salinidade foi suficiente para reduzir o diâmetro do colo da planta. A diferença entre S1 e S2 pode ser explicada pela ausência de diferença significativa e ao paralelismo das duas curvas. $\mathrm{O}$ DC inicial das plantas submetidas à água S2, medido aos 22 DAT, foi maior que o DC das plantas irrigadas com a água S1 e, como não houve efeito da água S2 sobre esta variável, as curvas de crescimento permaneceram com diferença constante durante todo o período avaliado. O mesmo não ocorreu para a água S3, visto que a diferença entre S3 
e S2 aumentou de 8,00 para $9,86 \%$ no período entre o $22^{\circ}$ e o $63^{\circ}$ DAT, indicando redução na taxa de crescimento devido à maior salinidade da água.

Tabela 8. Resumo da ANAVA para o diâmetro do colo das plantas em quatro épocas distintas, para as diferentes salinidades da água, lâminas de irrigação e frequências de aplicação da lâmina L1.

\begin{tabular}{|c|c|c|c|c|}
\hline \multirow{3}{*}{ Fator } & \multicolumn{4}{|c|}{ Estatística F } \\
\hline & \multicolumn{4}{|c|}{ Dcolo $(\mathrm{cm})$} \\
\hline & 55 & 63 & 96 & 112 \\
\hline - Níveis de salinidade (S) & $3,88 *$ & $4,64^{*}$ & 1,64 & 1,74 \\
\hline Linear & $4,46^{*}$ & $6,25^{*}$ & 2,00 & 1,74 \\
\hline Quadr. & 3,31 & 3,03 & 1,27 & 1,74 \\
\hline - Lâmina (L) & 0,08 & 0,10 & 0,13 & 0,18 \\
\hline - Lâmina (L)/Frequência (F) & $3,69 *$ & 2,91 & 2,37 & 1,85 \\
\hline \multirow[t]{2}{*}{ - Interação (S x LF) } & 1,76 & 2,30 & $3,72 *$ & $3,17 *$ \\
\hline & \multicolumn{4}{|c|}{ Valores médios } \\
\hline \multicolumn{5}{|l|}{ - Níveis de salinidade } \\
\hline S1 & $1,079 \mathrm{ab}$ & $1,139 \mathrm{ab}$ & 1,217 & 1,253 \\
\hline S2 & $1,110 \mathrm{a}$ & $1,160 b$ & 1,235 & 1,228 \\
\hline S3 & $1,002 b$ & $1,046 \mathrm{a}$ & 1,170 & 1,194 \\
\hline \multicolumn{5}{|l|}{ - Lâmina (L) } \\
\hline L0 & 1,057 & 1,123 & 1,213 & 1,236 \\
\hline L1 & 1,067 & 1,112 & 1,199 & 1,219 \\
\hline \multicolumn{5}{|l|}{ - Lâmina (L)/Frequência (F) } \\
\hline L1F1 & 1,013 & 1,064 & 1,151 & 1,177 \\
\hline L1F2 & 1,121 & 1,159 & 1,247 & 1,262 \\
\hline
\end{tabular}

* Significativo ao nível de 0,05 de probabilidade pelo teste $\mathrm{F}$

Médias seguidas de mesma letra não diferem entre sí pelo teste de Tukey, ao nível de 0,05 de probabilidade, para cada fator dentro de uma mesma coluna.

Para as diferentes lâminas de irrigação, a análise estatística demonstrou não haver influência deste fator no DC das plantas para nenhuma das medições efetuadas. Já para a frequência de aplicação de L1, o teste F verificou haver diferença significativa para a medição realizada aos 55 DAT, embora o teste de Dunnett demonstrou que as diferentes frequências não diferiram significativamente de L0. Pelas médias apresentadas na Tabela 8, verifica-se que o DC para a lâmina L0 foi inferior a L1F2 e 
superior a L1F1 para todas as medições avaliadas, ou seja, L0 ocupou uma posição intermediária entre as duas frequências de aplicação de L1, o que resultou em diferenças não significativas para as frequências em comparação com L0.

O teste para a interação $\mathrm{S} \times \mathrm{LF}$ indicou haver diferença significativa para as medições realizadas aos 96 e 112 DAT, indicando que as diferentes frequências de aplicação da lâmina L1, juntamente com L0, comportaram-se de maneira semelhante entre os níveis de salinidade e vice-versa. Pela Tabela 9, verifica-se a existência de diferença significativa para a frequência de aplicação de L1, em relação a L0, dentro do nível S1 de salinidade da água, sendo que a aplicação de L1 reduziu o DC das plantas, independente da frequência utilizada. Para os níveis S2 e S3, as diferentes frequências não diferiram significativamente de L0, embora as médias demonstrem que a aplicação da lâmina L1 tenha proporcionado um aumento no DC, com vantagem para a frequência F2.

Tabela 9. Teste de Dunnett unilateral para a lâmina de irrigação L1, associada à frequência de aplicação (LF), comparadas com a lâmina L0, dentro dos níveis de salinidade, para as medições realizadas aos 96 e 112 dias após o transplantio.

\begin{tabular}{c|c|c|c|c|c|c}
\hline \hline \multirow{2}{*}{ Fator } & \multicolumn{5}{|c}{ Dias após o transplantio } \\
\cline { 2 - 7 } & \multicolumn{3}{|c|}{96} & \multicolumn{3}{c}{112} \\
\cline { 2 - 7 } & \multicolumn{2}{|c}{ Lâmina (L)/Frequência (F) } & \multicolumn{2}{c}{ Lâmina (L)/Frequência (F) } \\
\cline { 2 - 7 } & L0 & L1F1 & L1F2 & L0 & L1F1 & L1F2 \\
\cline { 2 - 7 } & \multicolumn{7}{c}{ Valores médios } \\
- Níveis de salinidade & 1,362 & $1,127^{* *}$ & $1,162^{*}$ & 1,372 & $1,147^{* *}$ & $1,182^{*}$ \\
S1 & 1,173 & 1,205 & 1,328 & 1,198 & 1,242 & 1,347 \\
S2 & 1,103 & 1,122 & 1,250 & 1,138 & 1,143 & 1,257 \\
S3 &
\end{tabular}

* Significativo ao nível de 0,05 de probabilidade pelo teste de Dunnett

** Significativo ao nível de 0,01 de probabilidade pelo teste de Dunnett

\subsubsection{3 Área foliar unitária, índice de área foliar e matéria seca das folhas}

A área foliar unitária (AFU) e o índice de área foliar (IAF) encontram-se na Figura 11. Para o $115^{\circ}$ DAT, as medições foram realizadas apenas em uma parcela de cada tratamento, utilizando-se duas plantas de cada parcela, cujo desenvolvimento 
vegetativo foi acompanhado durante todo o ciclo de cultivo. Observa-se que a água S1 apresentou os maiores valores de AFU, exceto para o $115^{\circ}$ DAT. Por outro lado, o IAF para a água S1 foi maior em todas as medições. Isso indica que, embora a área foliar média das plantas ter sido menor na última medição, a área foliar total, a qual representa a capacidade fotossintética total da planta, foi maior para S1 do que para S2 e S3 durante todo o ciclo de cultivo.

Tabela 10. Resumo da ANAVA para Área foliar unitária e Índice de área foliar das plantas de pepino em três épocas distintas, para as diferentes salinidades da água, lâminas de irrigação e frequências de aplicação da lâmina L1.

\begin{tabular}{|c|c|c|c|c|c|c|}
\hline \multirow{3}{*}{ Fator } & & \multicolumn{5}{|c|}{ Estatística F } \\
\hline & \multicolumn{3}{|c|}{ Área Foliar Unitária $\left(\mathrm{cm}^{2}\right)$} & \multicolumn{3}{|c|}{ Índice de Área Foliar } \\
\hline & 34 & 55 & 63 & 34 & 55 & 63 \\
\hline - Níveis de salinidade (S) & 2,48 & $4,64 *$ & 0,05 & $3,81 *$ & $44,82 *$ & 0,36 \\
\hline Linear & 3,62 & $9,07 * *$ & 0,02 & $6,87 *$ & $9,64 * *$ & 0,65 \\
\hline Quadr. & 1,34 & 0,21 & 0,08 & 0,84 & 0,02 & 0,06 \\
\hline - Lâmina de irrigação (L) & 0,05 & 0,15 & 1,51 & 0,01 & 0,11 & 0,57 \\
\hline - Lâmina (L)/Frequência (F) & 0,80 & 0,23 & 0,77 & 1,31 & 0,80 & 0,97 \\
\hline \multirow[t]{2}{*}{ - Interação (S x LF) } & 0,31 & 1,14 & 0,39 & 0,54 & 0,61 & 0,23 \\
\hline & \multicolumn{6}{|c|}{ Valores médios } \\
\hline \multicolumn{7}{|l|}{ - Níveis de salinidade } \\
\hline S1 & 349,7 & 441,5 & 429,5 & 1,50 & 2,07 & 2,46 \\
\hline S2 & 320,3 & 419,3 & 422,5 & 1,32 & 1,93 & 2,36 \\
\hline S3 & 318,0 & 401,3 & 426,1 & 1,25 & 1,78 & 2,31 \\
\hline \multicolumn{7}{|l|}{ - Lâmina (L) } \\
\hline L0 & 327,3 & 424,0 & 410,5 & 1,36 & 1,94 & 2,30 \\
\hline L1 & 330,3 & 419,2 & 433,9 & 1,36 & 1,92 & 2,41 \\
\hline \multicolumn{7}{|l|}{ - Lâmina (L)/Frequência (F) } \\
\hline $\mathrm{L} 1 \mathrm{~F} 1$ & 320,4 & 422,7 & 431,1 & 1,28 & 1,86 & 2,31 \\
\hline $\mathrm{L} 1 \mathrm{~F} 2$ & 340,2 & 415,5 & 436,5 & 1,44 & 1,97 & 2,52 \\
\hline
\end{tabular}

* Significativo ao nível de 0,05 de probabilidade pelo teste $\mathrm{F}$

** Significativo ao nível de 0,01 de probabilidade pelo teste $\mathrm{F}$

Como pode ser observado na Tabela 10, a AFU foi afetada linearmente pela salinidade da água de irrigação para a medição realizada aos 55 DAT. Para o IAF, a salinidade resultou em diferenças significativas para as medições do $35^{\circ}$ e $55^{\circ}$ DAT. Como o PDAF determinado aos 55 DAT também foi utilizado na determinação da AFU 
aos 63 DAT, a área foliar das plantas submetidas ao tratamento S3 pode ter sido superestimada, resultando na ausência de diferenças significativas, como consequência da variação do PDAF em função do tempo.

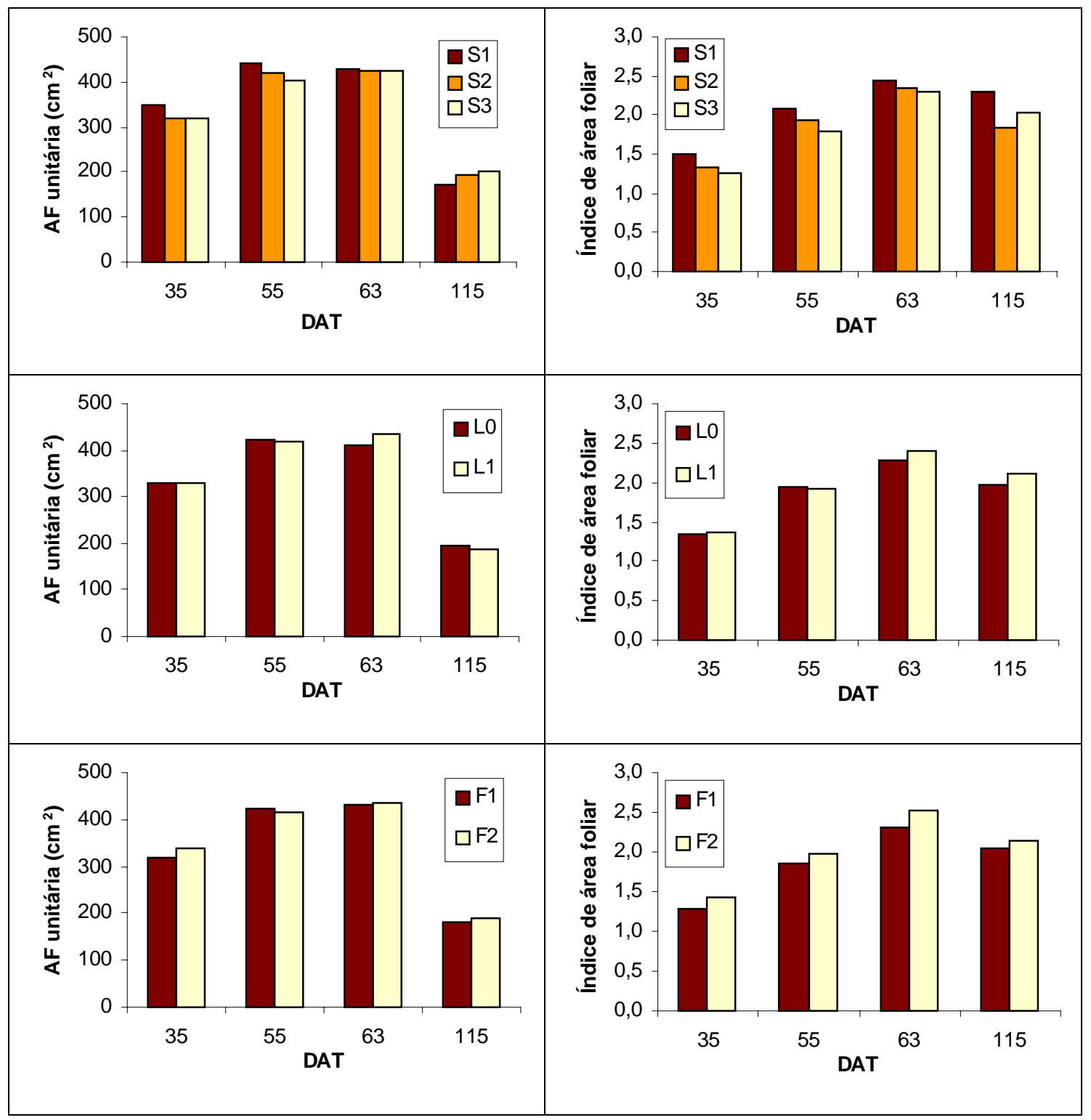

Figura 11. Área foliar unitária e Índice de área foliar das plantas de pepino para cada salinidade da água, lâmina de irrigação e frequência de aplicação da lâmina L1. 
As lâminas de irrigação não resultaram em diferença estatística na AFU e o IAF, embora L1 tenha exercido ligeira vantagem para a maioria das determinações. Aos 55 DAT, a AFU para a lâmina L0 superou L1 em 1,13\% e para o IAF, em 1,03\%.

As frequências de aplicação de L1 também não afetaram significativamente a AFU e o IAF, sendo F2 superior a F1 em todas as determinações, com exceção da AFU aos 55 DAT, quando F1 foi 1,70\% maior que F2.

A porcentagem de matéria seca nas folhas (MSF), determinada por ocasião do final do cultivo, encontra-se na Figura 12. Verifica-se que esta aumentou com o aumento da salinidade da água de irrigação, o que também foi observado por Blanco et al. (1999) em folhas de alface e Medeiros (1998) para a cultura do pimentão. As diferentes lâminas de irrigação não resultaram em diferenças na MSF, sendo que a frequência de aplicação de L1 proporcionou um aumento de 2,78\%.

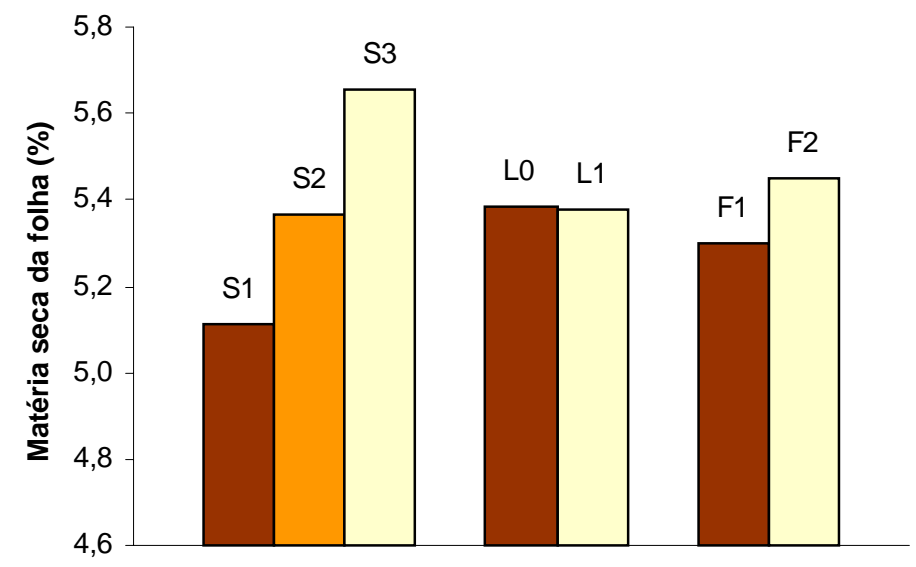

Figura 12. Porcentagem de matéria seca das folhas no final do ciclo do pepino.

\subsubsection{Evolução da salinidade do solo}

Sob condições irrigadas, a absorção de água pelas plantas e a evaporação pela superfície do solo fazem com que os sais se concentrem na zona radicular, sendo esta concentração proporcional ao volume de água removido (Bresler et al., 1982).

A Figura 13 mostra a evolução dos perfis de salinidade do solo entre 20 e 117 DAT. Verifica-se que aos 20 DAT a salinidade era maior para as camadas mais superficiais, sendo praticamente constante à partir dos $30 \mathrm{~cm}$ de profundidade. $\mathrm{O}$ 
aumento na salinidade em todas as profundidades foi proporcional à salinidade da água de irrigação, sendo que aos 117 DAT a salinidade no perfil aumentou, independente da água utilizada. Pode-se observar que a irrigação com a água S1 resultou numa salinidade final na profundidade de $10 \mathrm{~cm}$ de $2,13 \mathrm{dS} \cdot \mathrm{m}^{-1}$, a qual é inferior à salinidade limiar para o pepino que, de acordo com Maas \& Hoffman (1977), é de 2,5 dS.m ${ }^{-1}$. A salinidade final do solo nesta profundidade foi superior à salinidade da água de irrigação, exceto para S3.

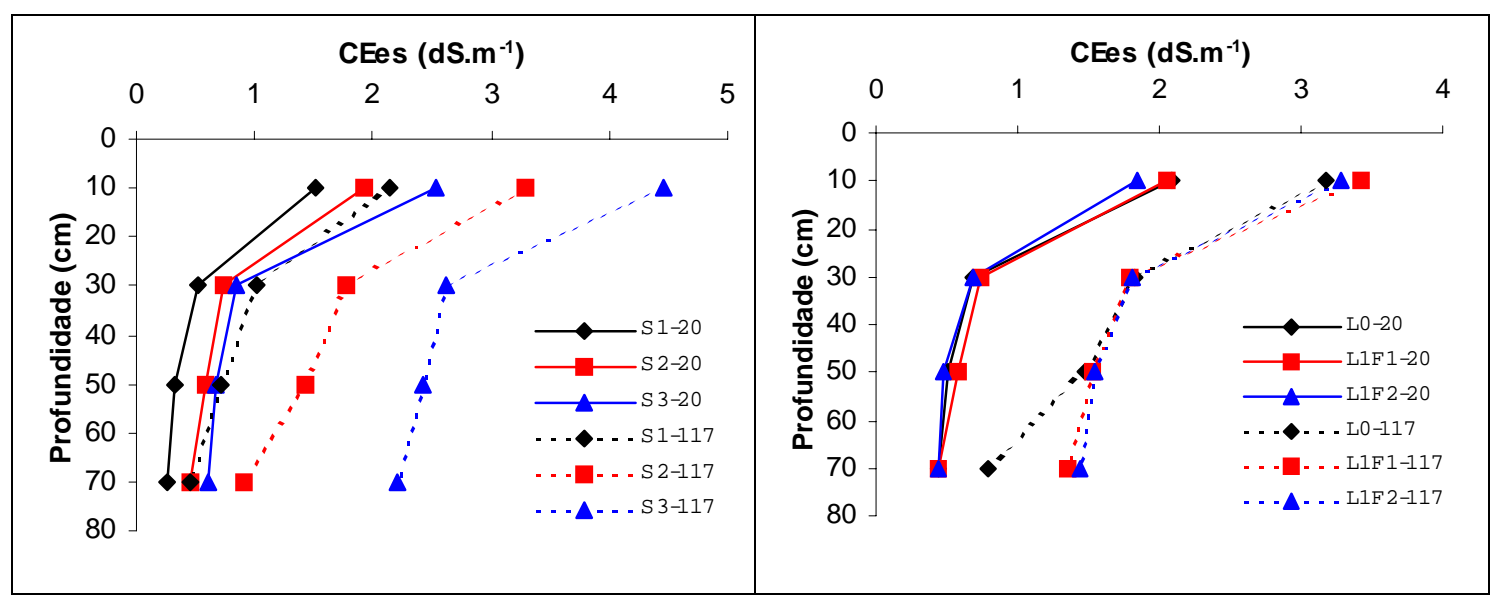

Figura 13. Perfis de salinidade do solo, expressos em condutividade elétrica do extrato de saturação (CEes), para as diferentes salinidades da água, lâminas de irrigação e frequências de aplicação de L1 aos 20 e 117 dias após o transplantio.

Para as diferentes lâminas de irrigação e frequência de aplicação de L1, verifica-se que os perfis de salinidade foram semelhantes, embora para L0 a salinidade na profundidade de $70 \mathrm{~cm}$ foi inferior às demais. Como as parcelas submetidas à lâmina L0 foram as que receberam menor volume de água durante o período de cultivo, é de se esperar que a fração de água lixiviada para camadas mais profundas seja significativamente inferior àquelas que receberam a lâmina L1. Observa-se também que, tanto para as diferentes salinidades da água quanto para as lâminas e frequências, a salinidade na profundidade de $10 \mathrm{~cm}$ foi bastante superior às demais. Devido ao curto período de tempo em que o solo foi submetido às irrigações salinas (aproximadamente 3 meses), não houve tempo suficiente para que o solo atingisse o equilíbrio dinâmico de 
sais para esta profundidade, fazendo com que a lâmina de lixiviação apresentasse baixa eficiência na remoção do excesso de sais. Além disso, a distribuição exponencial de extração de água do solo pelas raízes, proposta por Hoffman \& Van Genuchten (1983), resulta na maior evapotranspiração nas camadas superficiais de solo, fazendo com que a água de irrigação fique retida nesta região. Resultados semelhantes foram encontrados por Medeiros (1998), Cruciani et al. (1996) entre outros.

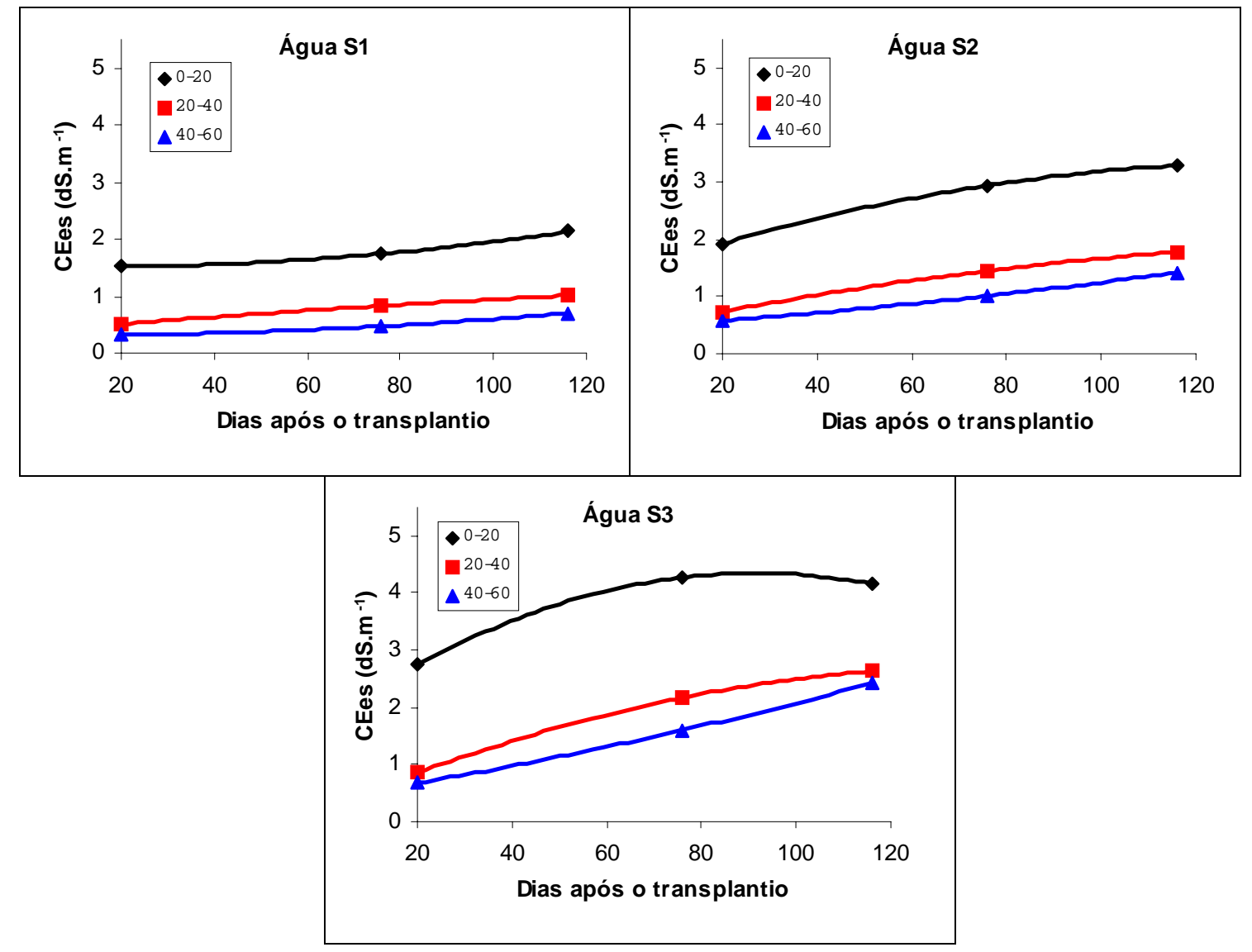

Figura 14. Evolução da salinidade do solo em diferentes profundidades para cada salinidade da água de irrigação.

Na Figura 14 está apresentada a evolução da salinidade do solo em cada profundidade para as diferentes salinidades da água de irrigação. Verifica-se que a salinidade é inversamente proporcional à profundidade, ou seja, os maiores valores de condutividade elétrica são observados sempre para as camadas mais superficiais, em 
comparação com as mais profundas. Para todas as amostragens efetuadas, a salinidade do solo nos tratamentos irrigados com águas mais salinas foi superior à dos tratamentos de água menos salina em todas as profundidades. Para os tratamentos de água S1, o aumento foi praticamente constante ao longo do tempo, com pequena variação entre a primeira e a última amostragem, resultando em um aumento de 0,61 dS.m ${ }^{-1}$ durante o ciclo da cultura para a profundidade de 0-20 $\mathrm{cm}$. O aumento constante também foi observado para os tratamentos de água S2. Porém, para a água S3, ocorreu aumento rápido da primeira para a segunda amostragens na profundidade de $0-20 \mathrm{~cm}$, sendo que a salinidade estabilizou após esta data.

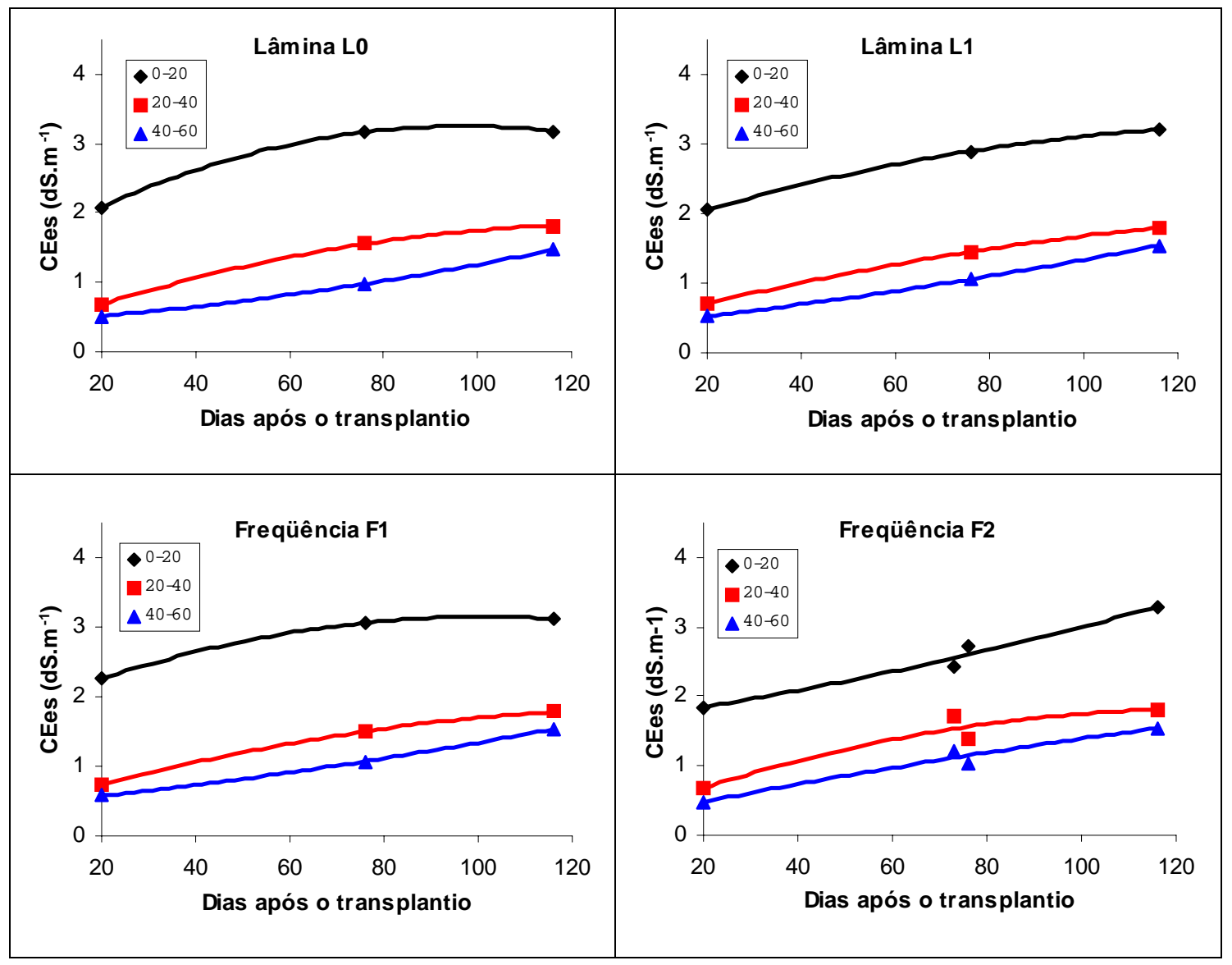

Figura 15. Evolução da salinidade do solo em diferentes profundidades para cada lâmina de irrigação e frequência de aplicação de L1. 
Para as lâminas de irrigação e frequências de aplicação de L1, verifica-se na Figura 15 que L0 proporcionou um aumento mais rápido da salinidade do que L1 para a profundidade de 0-20 cm, indicando que L1 resultou na lixiviação de parte dos sais para camadas mais profundas. Este fato, porém, não impediu o aumento da salinidade do solo, sendo que no final do cultivo a salinidade para L0 e L1 foram iguais, como consequência da estabilização da salinidade do solo para L0 após a segunda amostragem. Para a frequência de aplicação de L1, o comportamento da curva para a profundidade de 0-20 cm foi semelhante ao observado para as lâminas de irrigação, sendo que F2 resultou em um retardamento da salinização do solo em relação a F1, para a qual a salinidade aumentou rapidamente, estabilizando-se após a segunda amostragem.

Pela Figura 16 observa-se que a salinidade antes e depois da aplicação de L1 nos tratamentos de frequência F2 apresentou comportamento similar entre as salinidades da água de irrigação. De maneira geral, a salinidade do solo na profundidade de 0-20 cm apresentou variação despresível após a aplicação de L1 para as parcelas irrigadas com a água S1 e S3, enquanto que para S2 a salinidade aumentou após a lixiviação. No dia em que a esta foi realizada, as salinidades das águas S1, S2 e S3 foram, 1,53, 3,10 e $5,15 \mathrm{dS} . \mathrm{m}^{-1}$, respectivamente. Portanto, observa-se que, para a água $\mathrm{S} 1$, a salinidade do solo antes da aplicação da lâmina foi maior que a salinidade da água utilizada na lixiviação, enquanto que para S2 e S3 a salinidade do solo foi inferior às respectivas águas de lixiviação. Como a salinidade média das parcelas irrigadas com S3 manteve-se sempre com altos teores de umidade, dada à redução da evapotranspiração devido ao baixo potencial osmótico do solo, a salinidade da água utilizada na lixiviação não alterou a salinidade do solo, pois o balanço de sais nesta profundidade já havia atingido o equilíbrio, como pode ser observado pela Figura 13, a qual demonstra que a salinidade na profundidade de 0-20 $\mathrm{cm}$ se manteve constante após o $75^{\circ}$ DAT. Já para a água S2, a aplicação da lâmina de lixiviação resultou no aumento da salinidade na profundidade de 0-20 cm, enquanto que nas demais profundidades houve uma redução da salinidade do solo, sendo que após a lixiviação a salinidade continuou a aumentar e não apresentou tendência de equilíbrio, como observado para S3. Com isso, a lixiviação resultou no 
aumento da salinidade nesta profundidade, uma vez que os sais movimentam-se mais lentamente no solo do que a frente de avanço da água.

Khan et al. (1996) demonstram que a distribuição de solutos no solo aplicados via fertirrigação por gotejamento não acompanha a frente de avanço vertical da água, sendo que esta movimenta-se um pouco a frente dos sais. Este fato também pode resultar no acúmulo de sais na região radicular, mesmo quando uma fração de lixiviação é aplicada nas irrigações para o controle dos sais, o que irá depender da fração utilizada, da demanda evapotranspirativa e do tipo de solo.

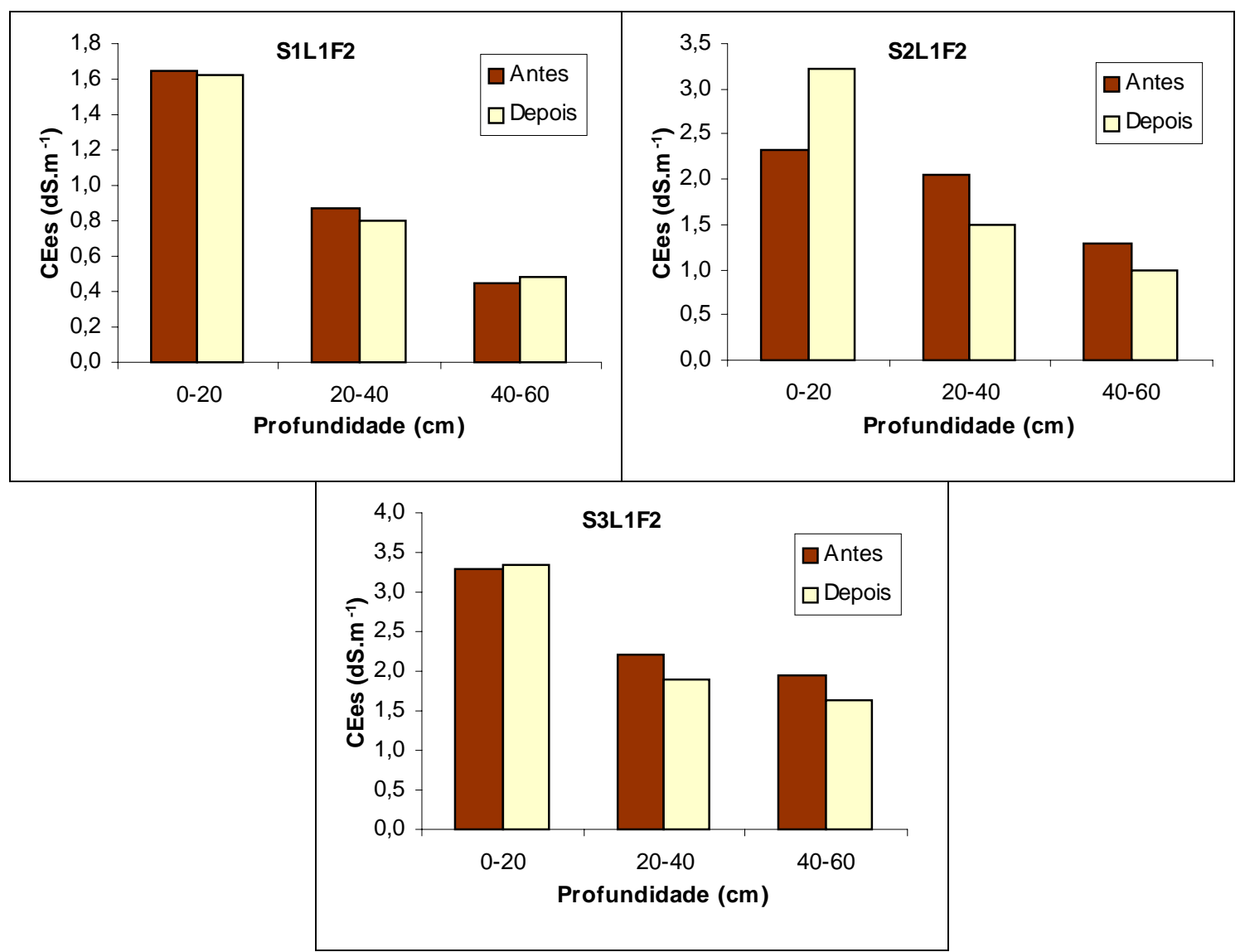

Figura 16. Evolução da salinidade do solo e salinidade antes e depois da aplicação da lâmina L1, para os tratamentos de frequência F2.

Deve-se salientar que a salinidade foi medida dentro do bulbo molhado produzido pela irrigação por gotejamento, sendo que nesta região, segundo Medeiros (1998), ocorre movimento de água e sais tanto vertical como lateralmente, o que pode 
produzir equilíbrios variados, dependendo da distância horizontal entre o ponto de amostragem e a fonte de água (gotejador).
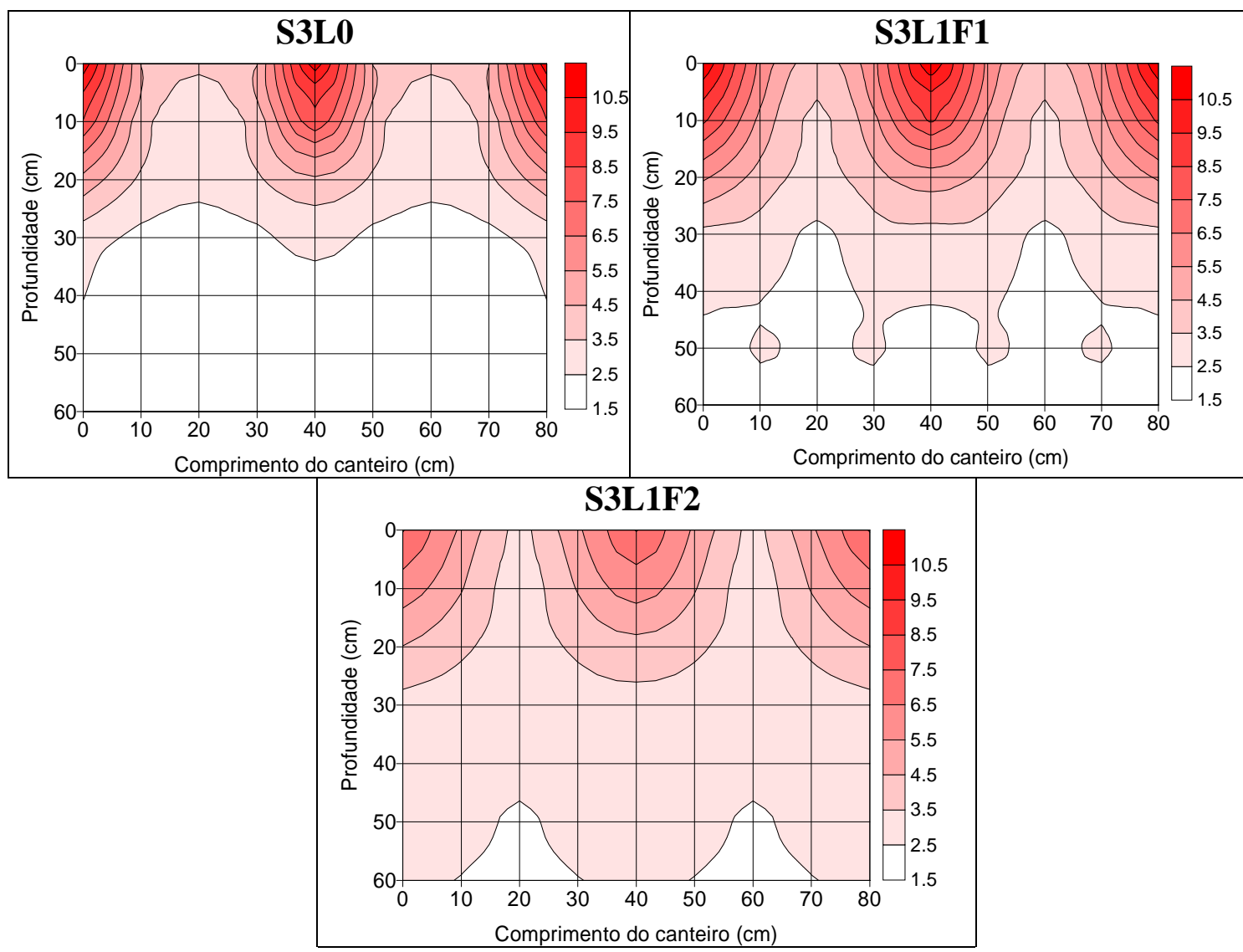

Figura 17. Perfis de salinidade ao longo do comprimento do canteiro, medidos no final do ciclo da cultura do pepino (plantas localizadas nas posições de 20 e $60 \mathrm{~cm}$, em relação ao comprimento do canteiro).

Pela Figura 17, observa-se que houve um acúmulo de sais na região periférica do bulbo, principalmente na camada mais superficial do solo. Isso acontece devido à ascensão capilar e ao movimento lateral de água e sais, logo após a infiltração da água de irrigação na área central do bulbo, seguida da evaporação pela superfície do solo e extração de água pelas plantas. Para a parcela que não recebeu a lâmina de lixiviação (S3L0), a maior concentração de sais foi localizada entre os bulbos de dois gotejadores consecutivos, próximo à superfície do solo, enquanto que para a parcela que recebeu a lâmina L1 em todas as irrigações (S3L1F1) a região de maior salinidade avançou 
lateralmente, provavelmente devido à maior sobreposição dos bulbos, o que resultou na maior movimentação lateral de sais. Para a parcela correspondente ao tratamento S3L1F2, a concentração de sais na região entre os bulbos foi menor do que para os demais tratamentos, porém a salinidade aumentou em profundidade nesta região, como consequência da movimentação vertical ou lixiviação dos sais. De maneira geral, verifica-se que a distribuição vertical de sais no perfil para as parcelas irrigadas com a água S3 foi coerente com os diferentes manejos da lâmina de irrigação adotados, visto que as parcelas que receberam a maior lâmina apresentaram maiores teores de sais nas camadas mais profundas e a aplicação acumulada de L1 no tratamento S3L1F2 promoveu um perfil salino mais uniforme.

Tabela 11. Resumo da ANAVA e médias da salinidade média do solo nas profundidades de 20,40 e $60 \mathrm{~cm}$ e da salinidade média final na profundidade de 0-40 cm, para as diferentes salinidades da água, lâmina de irrigação e frequência de aplicação da lâmina L1.

\begin{tabular}{c|cccc}
\hline \hline \multirow{2}{*}{ Fator } & \multicolumn{4}{|c}{ Estatística F } \\
\cline { 2 - 5 } & \multicolumn{4}{|c}{ Salinidade do solo $\left(\mathrm{dS} . \mathrm{m}^{-1}\right)$} \\
\cline { 2 - 5 } & 20 & 40 & 60 & Final \\
\hline \hline - Níveis de salinidade (S) & $90,53^{* *}$ & $243,58^{* *}$ & $238,31^{* *}$ & $114,12^{* *}$ \\
Linear & $179,73^{* *}$ & $483,48^{* *}$ & $475,60^{* *}$ & $227,61^{* *}$ \\
Quadr. & 1,32 & 3,68 & 1,02 & 0,62 \\
\hline - Lâmina de irrigação (L) & 2,83 & 0,21 & 2,26 & 0,48 \\
\hline - Lâmina (L)/Frequência (F) & 1,80 & 0,13 & 1,22 & 0,26 \\
\hline - Interação (S x LF) & 1,32 & 1,04 & 1,33 & 0,99 \\
\hline - Níveis de salinidade & \multicolumn{4}{|c}{ Valores médios } \\
S1 & 1,79 & 0,80 & 0,49 & 1,28 \\
S2 & 2,75 & 1,39 & 1,00 & 2,16 \\
S3 & 3,73 & 1,98 & 1,60 & 3,16 \\
\hline L0 & \multicolumn{4}{|c}{} \\
L1 & 2,90 & 1,40 & 0,98 & 2,15 \\
- Lâmina (L) & 2,69 & 1,39 & 1,05 & 2,23 \\
\hline L1F1 & 2,75 & 1,38 & 1,06 & 2,24 \\
L1F2 & 2,62 & 1,39 & 1,04 & 2,22 \\
\hline - Lâmina (L)/Frequência (F) & \multicolumn{4}{|c}{}
\end{tabular}

** Significativo ao nível de 0,01 de probabilidade pelo teste $\mathrm{F}$ 
Verifica-se na Tabela 11 que as médias da salinidade do solo para as profundidades de 20, 40 e $60 \mathrm{~cm}$, bem como a salinidade média da camada $0-40 \mathrm{~cm}$, aumentaram linearmente com a salinidade da água de irrigação, porém não foram afetadas pelas lâminas de irrigação, concordando com dados obtidos por Medeiros (1998). A frequência F2 de aplicação da lâmina L1 também não proporcionou a redução da salinidade média do solo, como era esperado.

A ausência de diferença significativa para as lâminas de irrigação pode estar relacionada ao reduzido período de cultivo e à aplicação de pequeno volume de água, que foi de $198 \mathrm{~mm}$ na área cultivada (aproximadamente $396 \mathrm{~mm}$ na área molhada). Além disso, o solo argiloso possui alta capacidade de retenção de água, o que leva a um aumento no tempo necessário para atingir o equilíbrio dinâmico de sais no solo e, consequentemente, retarda o deslocamento de sais para as camadas mais profundas. Quanto à frequência de aplicação de L1, verifica-se pela Figura 15 que a redução da salinidade foi apenas momentânea, sendo que esta aumentou rapidamente após a lixiviação, fazendo com que a salinidade média para as frequências F1 e F2 fossem praticamente iguais para todas as profundidades amostradas (Tabela 11).

\subsubsection{Potencial mátrico}

O potencial mátrico $(\Psi \mathrm{m})$ é um dos componentes do potencial total da água no solo e, de maneira simples, o $\Psi \mathrm{m}$ reflete a energia com que a água está retida pela matriz do solo e, com isso, quanto mais úmido este estiver, maior será o valor de $\Psi \mathrm{m}$, uma vez sua variação é dada em escala negativa, ou seja, quanto menor a umidade do solo, mais negativo (ou menor) será o $\Psi$ m. A irrigação com água de salinidade elevada promove o acúmulo de sais no solo e, consequentemente, a redução do potencial osmótico, resultando em uma menor absorção de água pelas plantas em decorrência da redução do potencial total da água no solo. Com isso, pode-se avaliar os efeitos da salinidade do solo sobre a absorção de água pelas plantas através do monitoramento do $\Psi \mathrm{m}$ do solo, desde que a lâmina de irrigação seja a mesma para as diferentes condições de salinidade. 
No Apêndice 6, verifica-se que o módulo do potencial mátrico, $|\Psi \mathrm{m}|$, foi maior para os tratamentos irrigados com a água $\mathrm{S} 1$, apresentando bastante variação entre duas irrigações consecutivas, o que indica grande absorção radicular de água do solo. A oscilação dos valores de $|\Psi \mathrm{m}|$ durante o ciclo foi tanto menor quanto mais salina foi a água de irrigação, indicando pouca variação de umidade no solo, ou seja, baixa capacidade de absorção de água pelas raízes.

O $|\Psi \mathrm{m}|$ médio a 15 e $30 \mathrm{~cm}$ de profundidade, bem como o $|\Psi \mathrm{m}|$ médio na região radicular, reduziram linearmente com o aumento da salinidade da água, confirmando as afirmações feitas acima, como pode ser observado na Tabela 12. Estes também foram afetados significativamente pela frequência F1 de aplicação da lâmina L1, devido à maior quantidade de água aplicada em cada irrigação, em comparação com L0. Para a frequência F2, não houve diferença estatística em relação a L0.

As irrigações para os tratamentos L1F2 foram realizadas de forma idêntica aos tratamentos L0 até o $74^{\circ}$ DAT, produzindo valores de potencial mátrico semelhantes entre estes. Após esta data, com a aplicação da lâmina L1 acumulada nos tratamentos L1F2, houve um decréscimo no $|\Psi \mathrm{m}|$, o qual aumentou gradativamente com o tempo e, após duas semanas da aplicação, o potencial mátrico de L1F2 equiparou-se ao de L0, permanecendo com valores semelhantes até o final do ciclo da cultura. Portanto, o $|\Psi \mathrm{m}|$ médio destes tratamentos foram bastante próximos durante o período, o que levou diferenças não significativas.

Para o $|\Psi \mathrm{m}|_{15}$, verifica-se que as diferentes lâminas de irrigação não resultaram em diferenças significativas, embora a média para L0 tenha sido $23 \%$ superior a L1 devido à menor quantidade de água aplicada. Para o $|\Psi \mathrm{m}|_{30}$ e $|\Psi \mathrm{m}|$ médio na região radicular, as lâminas de irrigação tiveram efeito estatisticamente significativos, resultando em diferenças de 63,2 e 48,7\%, respectivamente, com vantagem para L0. 
Tabela 12. Resumo da ANAVA e médias do potencial mátrico médio do solo nas profundidades de 15 e $30 \mathrm{~cm}$, bem como do potencial mátrico médio na região radicular, para as diferentes salinidades da água, lâmina de irrigação e frequência de aplicação da lâmina L1.

\begin{tabular}{|c|c|c|c|}
\hline \multirow{3}{*}{ Fator } & \multicolumn{3}{|c|}{ Estatística F } \\
\hline & \multicolumn{3}{|c|}{ Potencial mátrico $(\mathrm{kPa})$} \\
\hline & 15 & 30 & Médio \\
\hline - Níveis de salinidade (S) & $9,02 * *$ & $9,19 * *$ & $11,01 * *$ \\
\hline Linear & $17,56^{* *}$ & $18,35^{* *}$ & $21,83 * *$ \\
\hline Quadr. & 0,48 & 0,02 & 0,19 \\
\hline - Lâmina de irrigação (L) & 3,53 & $10,28 * *$ & $8,20 *$ \\
\hline - Lâmina (L)/Frequência (F) & 2,28 & $7,23 * *$ & $5,53 *$ \\
\hline \multirow[t]{2}{*}{ - Interação (S x LF) } & 0,83 & 0,33 & 1,15 \\
\hline & \multicolumn{3}{|c|}{ Valores médios $^{1}$} \\
\hline \multicolumn{4}{|l|}{ - Níveis de salinidade } \\
\hline S1 & 10,30 & 11,10 & 10,70 \\
\hline $\mathrm{S} 2$ & 7,15 & 8,19 & 7,67 \\
\hline S3 & 4,73 & 4,68 & 4,69 \\
\hline \multicolumn{4}{|l|}{ - Lâmina (L) } \\
\hline L0 & 8,22 & 10,77 & 9,8 \\
\hline $\mathrm{L} 1$ & 6,68 & 6,60 & 6,59 \\
\hline \multicolumn{4}{|l|}{ - Lâmina (L)/Frequência (F) } \\
\hline L1F1 & $6,01 *$ & $5,07 *$ & $5,54 * *$ \\
\hline L1F2 & 7,35 & 8,13 & 7,64 \\
\hline
\end{tabular}

* Significativo ao nível de 0,05 de probabilidade pelo teste $\mathrm{F}$

** Significativo ao nível de 0,01 de probabilidade pelo teste $\mathrm{F}$

${ }^{1}$ Médias de Lâmina (L)/Frequência $(\mathrm{F})$ seguidas de $* \mathrm{e} * *$ correspondem a diferenças significativas ao nível de 0,05 e 0,01, respectivamente, pelo teste de Dunnett unilateral, em relação a L0.

\subsubsection{Produção e componentes de produção do pepino enxertado}

A produção comercial e total de pepino para as diferentes salinidades da água, lâminas de irrigação e frequências de aplicação da lâmina L1 estão apresentadas na Figura 18. Verifica-se que a produção comercial e total aumentaram de forma praticamente constante até o $90^{\circ}$ DAT, quando então o ritmo de produção de frutos foi intensificado devido ao grande número de ramificações laterais, independente dos tratamentos aos quais as plantas foram submetidas. As diferenças na produção 
acumulada aumentaram gradativamente até o final do ciclo, quando a produção comercial para as salinidades S2 e S3 foram reduzidas de 6,72 e 10,33\% em relação a S1 e a produção total de 4,77 e 9,63\%, respectivamente. Para as diferentes lâminas de irrigação, observou-se uma redução de 5,35 e 5,58\% para a lâmina L0 na produção total e comercial, respectivamente, em comparação com L1. Para as frequências de aplicação de L1, o aumento na produção total foi de 1,08 e 9,27\% para F1 e F2, respectivamente, em relação a L0. Para a produção comercial, F1 superou L0 em 2,37\%, enquanto que F2 em $8,59 \%$.

Com relação aos componentes de produção (Figura 19), verifica-se a redução no número de frutos comercial e total com o aumento da salinidade da água de irrigação. Para S2, o número de frutos total e comercial foi 5,09 e 10,83\% inferior à água S1 e, para S3, esta diferença foi de 7,05 e 11,43\%, respectivamente.

Para as lâminas de irrigação, L1 superou L0 em 3,78\% para o número total de frutos por planta e em 5,59\% para comercial, provavelmente devido ao maior volume de água aplicado nestes tratamentos, o que contribuiu para elevar o potencial mátrico do solo, resultando no aumento do potencial total e, consequentemente, facilitando a absorção de água pelas plantas submetidas aos tratamentos mais salinos.

As frequências de aplicação de L1 resultaram em aumento no número de frutos total e comercial, respectivamente, de 1,79 e 3,84\% para F1 e de 5,77 e 7,35\% para F2, em relação a $\mathrm{LO}$.

O peso médio dos frutos comerciais para cada colheita pode ser visualizado na Figura 20. Como o ponto de colheita foi determinado pelo comprimento do fruto (aproximadamente $20 \mathrm{~cm}$ ) e, devido à existência de alta correlação entre o comprimento e o peso do fruto (Figura 23), não houve grandes diferenças no peso médio dos frutos para nenhum dos fatores envolvidos. Em algumas colheitas, o peso médio dos frutos apresentou uma queda acentuada, o que é devido à colheita de frutos de comprimento inferior a $20 \mathrm{~cm}$ devido às condições de temperaturas elevadas e ritmo de crescimento intenso dos frutos, o que resultaria em frutos excessivamente grandes na colheita seguinte. O aumento do peso médio após o $90^{\circ}$ DAT foi devido à maior taxa de crescimento dos frutos ocorrida no final do ciclo, sendo que a frequência de colheita de 
2 dias foi mantida e o tamanho mínimo para que o fruto fosse colhido foi de $19 \mathrm{~cm}$, resultando em frutos maiores que $20 \mathrm{~cm}$ na colheita seguinte.

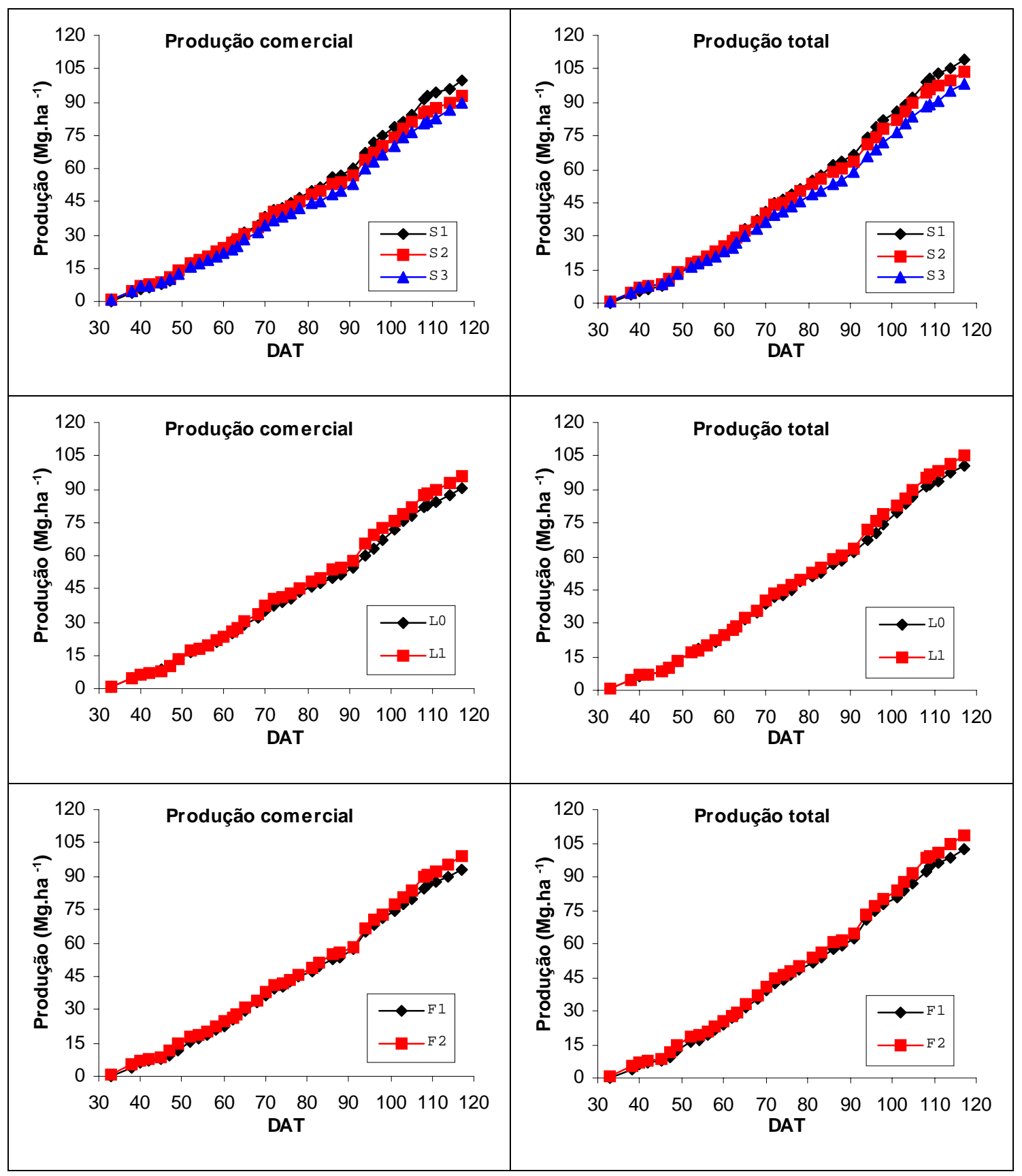

Figura 18. Produção comercial e total de pepino para cada salinidade da água, lâmina de irrigação e frequência de aplicação da lâmina L1. 


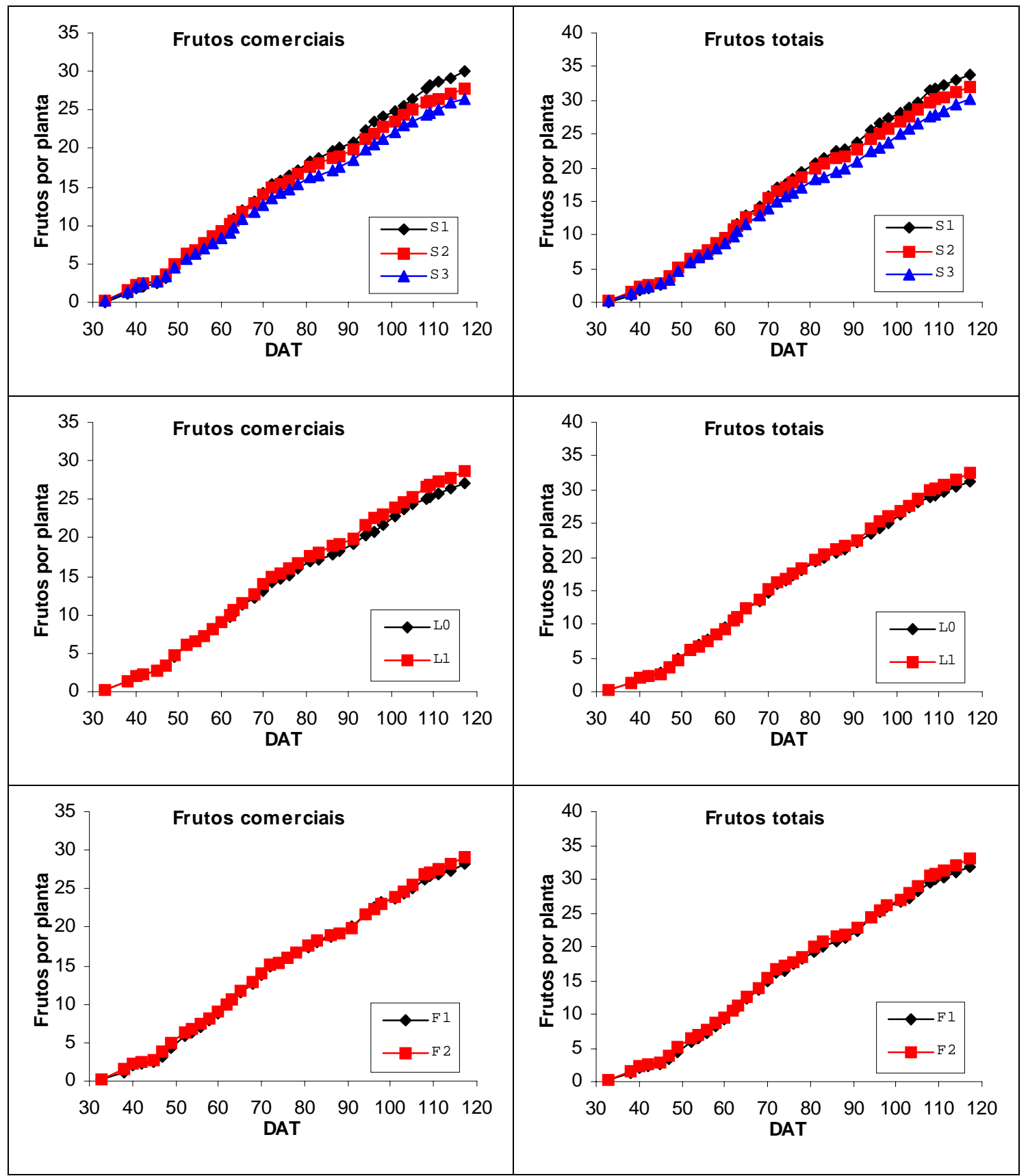

Figura 19. Número de frutos comercial e total por planta de pepino para cada salinidade da água, lâmina de irrigação e frequência de aplicação da lâmina L1.

Pelo Apêndice 7, verifica-se que a produção comercial e total não foram afetadas significativamente pela salinidade da água, bem como pelas lâminas de irrigação e pelas diferentes frequências de aplicação de L1, o que também ocorreu para o peso médio dos frutos e número total de frutos por planta. $\mathrm{O}$ número de frutos 
comerciais por planta reduziu linearmente com o aumento da salinidade da água, não sendo afetado significativamente pelas lâminas de irrigação e frequência de aplicação de L1. Portanto, pode-se dizer que o principal efeito da irrigação salina no pepino "Hokushin", enxertado sobre a abóbora híbrida Excite-Ikki, em ambiente protegido é a redução do número de frutos comercial por planta, uma vez que o peso médio dos frutos não foi afetado pela salinidade, concordando com os dados obtidos por Jones et al. (1989).

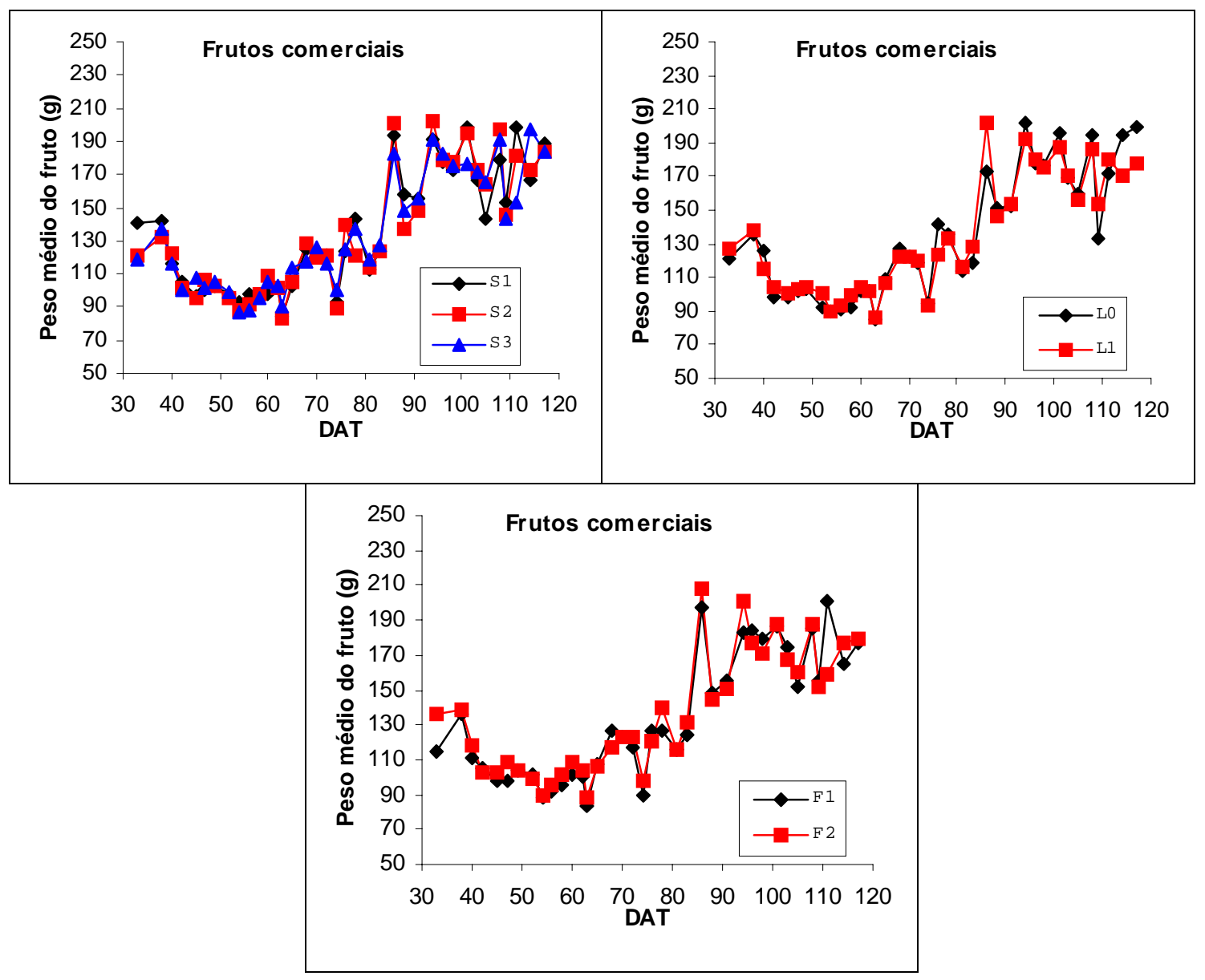

Figura 20. Peso médio dos frutos comerciais de pepino para cada salinidade da água, lâmina de irrigação e frequência de aplicação da lâmina L1.

Sonneveld \& Voogt (1978) obtiveram um decréscimo na produção de pepino da ordem de $17 \%$ para o aumento de uma unidade de salinidade da água de irrigação. Porém, a água salina foi aplicada através de um sistema de irrigação por aspersão, sendo 
que este sistema, conforme demonstram Gornat et al. (1973), não é adequado para a irrigação do pepino quando a água contém altos teores de sais, provocando alterações fisiológicas nas plantas.

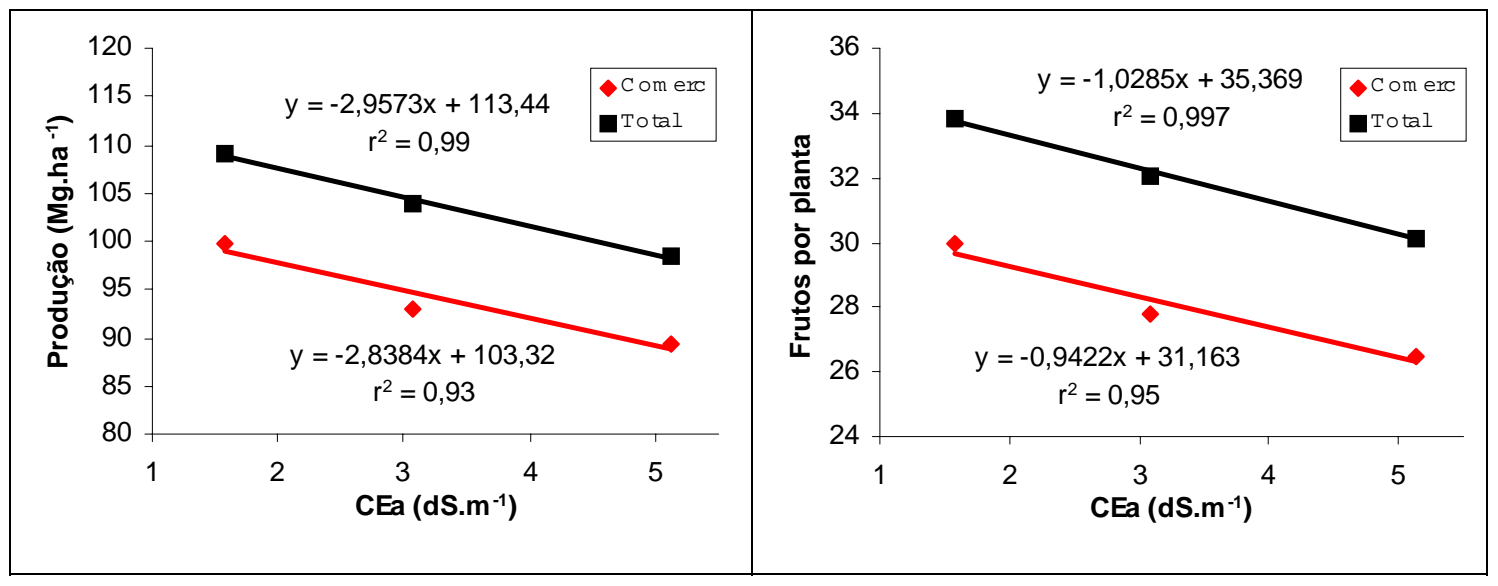

Figura 21. Equações de regressão para produção e número de frutos por planta, comercial e total, em função da salinidade da água de irrigação $(\mathrm{CEa})$.

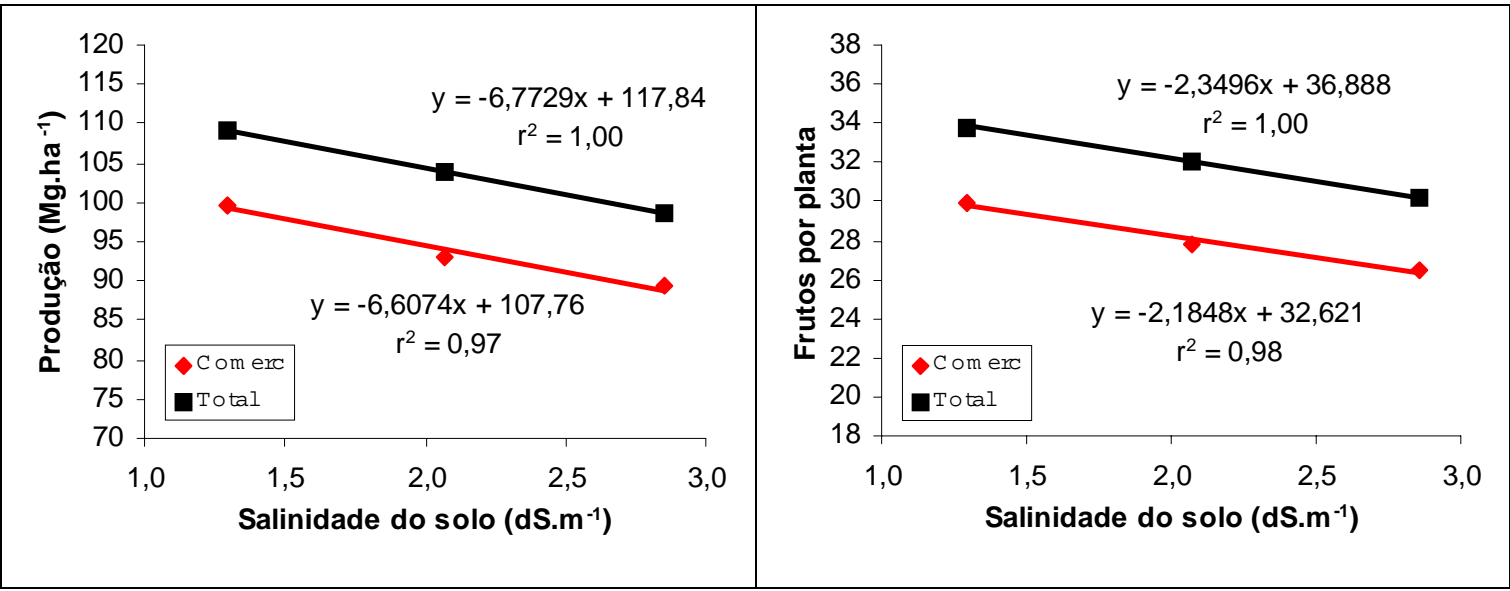

Figura 22. Equações de regressão para produção e número de frutos por planta, comercial e total, em função da salinidade média do solo na região radicular da cultura.

Na Figura 21 estão apresentadas as equações de regressão para a produção e número de frutos por planta em função da salinidade da água de irrigação. A redução na produção comercial e total foi de 2,84 e 2,96 Mg.ha-1 e a de frutos, comercial e total, de 0,94 e 1,03 frutos por planta, respectivamente, representando uma redução de 2,99 e 
$2,83 \%$ e de 3,33 e $3,19 \%$ para o incremento de uma unidade de salinidade da água de irrigação.

Para a salinidade média do solo na profundidade correspondente à região radicular da cultura, considerada como sendo $40 \mathrm{~cm}$, pode-se observar na Figura 22 que a redução na produção total e comercial foi de 6,71 e 7,24 \% e a de frutos, 7,58 e $8,04 \%$, respectivamente, para o aumento de uma unidade de salinidade do extrato de saturação. Estes valores estão abaixo daquele indicado por Maas \& Hoffman (1977), que afirmam que a redução na produção é da ordem de $13 \%$ para o aumento de uma unidade de salinidade do solo.

Jones et al. (1989) verificaram que os diferentes cultivares de pepino em ambiente protegido responderam de maneira diferenciada à salinidade da água de irrigação, com reduções na produtividade variando de 20 a $68 \%$ para a água de 4,0 dS.m ${ }^{-1}$, em relação às plantas do mesmo cultivar que foram irrigadas com água de 1,6 dS.m ${ }^{-1}$. Chartzoulakis (1990) verificou que o número de frutos por planta e o peso médio dos frutos reduziram significativamente quando a salinidade da água de irrigação foi superior a $1,3 \mathrm{dS} \cdot \mathrm{m}^{-1}$, sendo de $15,9 \%$ a redução de produtividade para cada unidade de salinidade acrescida na água de irrigação.

Com isso, pode-se verificar que a resposta do pepino à salinidade pode variar bastante, principalmente quando se utilizam diferentes cultivares, concordando com as afirmações de Maas \& Hoffman (1977) e Gorham (1995). Oda (1995) afirma que a enxertia proporciona maior tolerância das culturas à salinidade, bem como aumenta a capacidade de absorção de água e nutrientes.

Estes fatos associados levam a crer que, em comparação com dados da literatura, a pequena redução de produtividade obtida com o aumento da salinidade da água de irrigação pode estar relacionada ao cultivar utilizado, às condições de clima e solo em que o experimento foi conduzido e à maior tolerância do pepino enxertado à salinidade, em relação ao pepino não enxertado, não sendo possível determinar com exatidão o grau de influência que cada um destes fatores exerceu sobre os resultados obtidos. 


\subsubsection{Características dos frutos}

As características dos frutos medidas aos 38, 49, 65, 77, 90 e 107 DAT utilizando-se 3 frutos comerciais por parcela, escolhidos ao acaso, encontram-se apresentadas nas Figuras 24 a 26, de acordo com o fator envolvido.

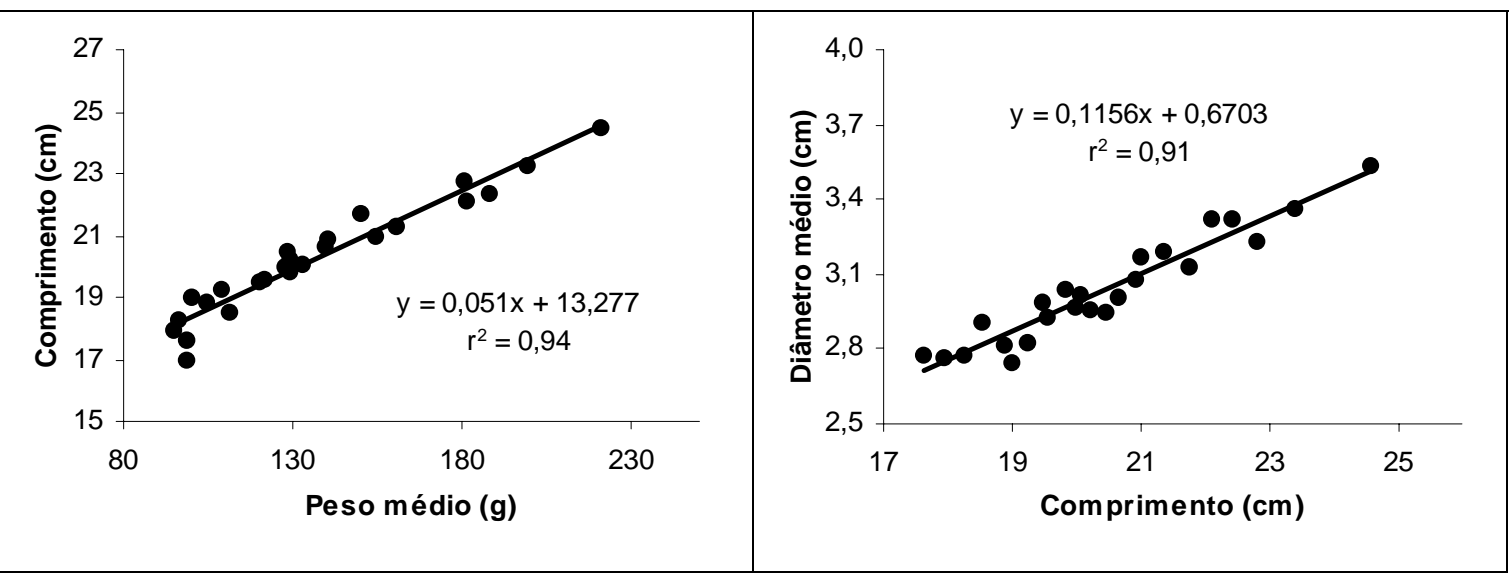

Figura 23. Relação entre o comprimento e o peso médio e entre o comprimento e o diâmetro médio dos frutos comerciais de pepino.

De maneira geral, o comprimento dos frutos não foi afetado por nenhum dos fatores, o que já era esperado visto que o pepino é colhido quando atinge determinado tamanho, ao contrário do tomate e pimentão que são colhidos quando apresentam determinado estágio de maturação dos frutos. O aumento no comprimento dos frutos observadno o final do ciclo da cultura, como comentado anteriormente, foi devido ao aumento na taxa de crescimento dos mesmos e, como o intervalo entre colheitas foi mantido em 2 dias, o comprimento ultrapassou os $20 \mathrm{~cm}$. O diâmetro médio do fruto também não apresentou grandes variações devido aos tratamentos, uma vez que a relação entre o comprimento e o diâmetro do fruto apresentou alta correlação (Figura 23), resultando também na pequena variação da relação comprimento/diâmetro para todos os fatores. 


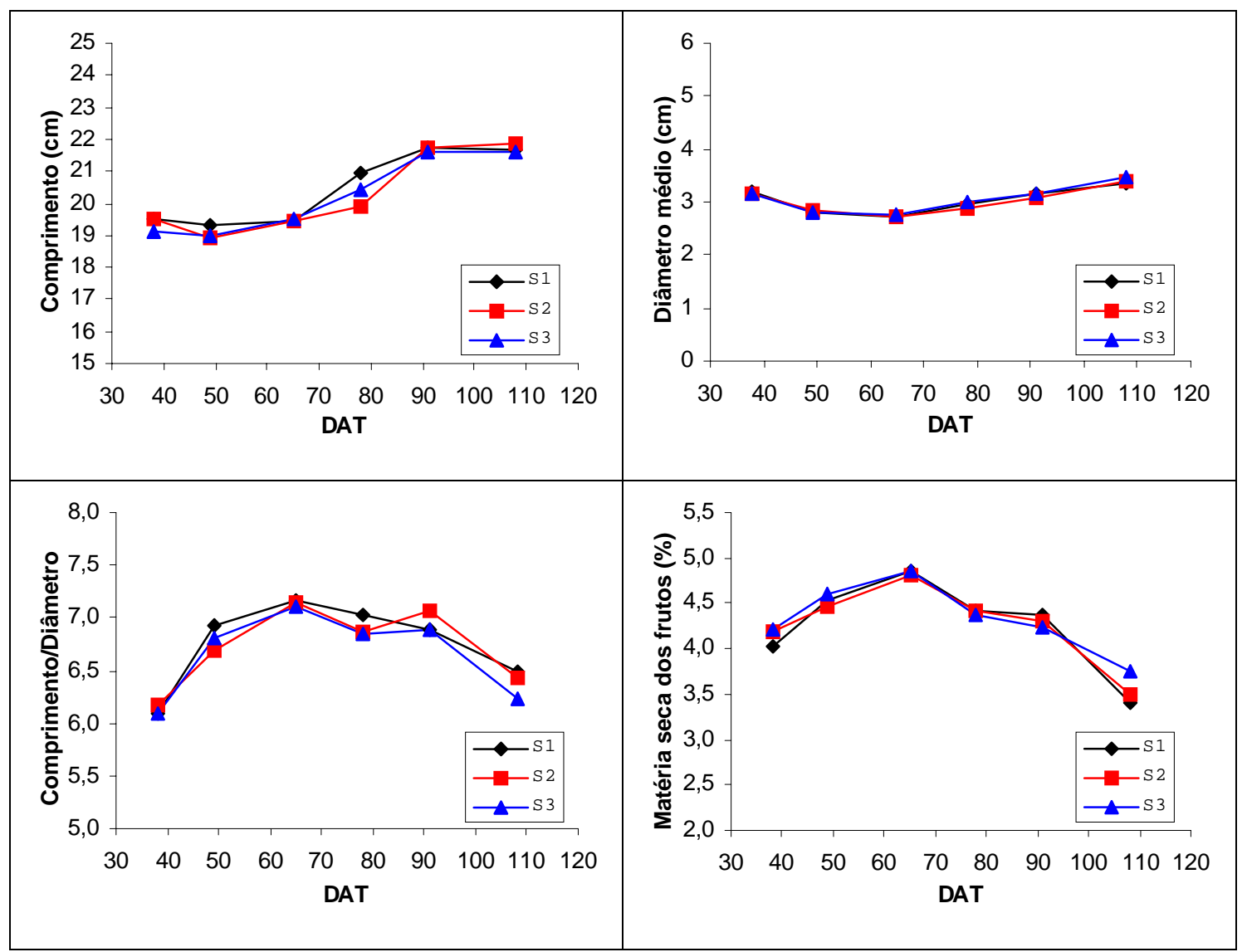

Figura 24. Características dos frutos para cada salinidade da água de irrigação.

A porcentagem de matéria seca dos frutos aumentou até o $65^{\circ}$ DAT, reduzindo constantemente para as determinações seguintes, independente do tratamento ao qual as plantas foram submetidas. Para outras hortaliças, Medeiros (1998) e Meiri et al. (1995) verificaram aumento na porcentagem de matéria seca dos frutos para as culturas do pimentão e melão, respectivamente, com o aumento da salinidade da água de irrigação.

A análise estatística, apresentada na Tabela 13, demonstrou não haver diferenças significativas para nenhuma das características dos frutos avaliada, sendo que todas elas apresentaram médias bastante semelhantes. 


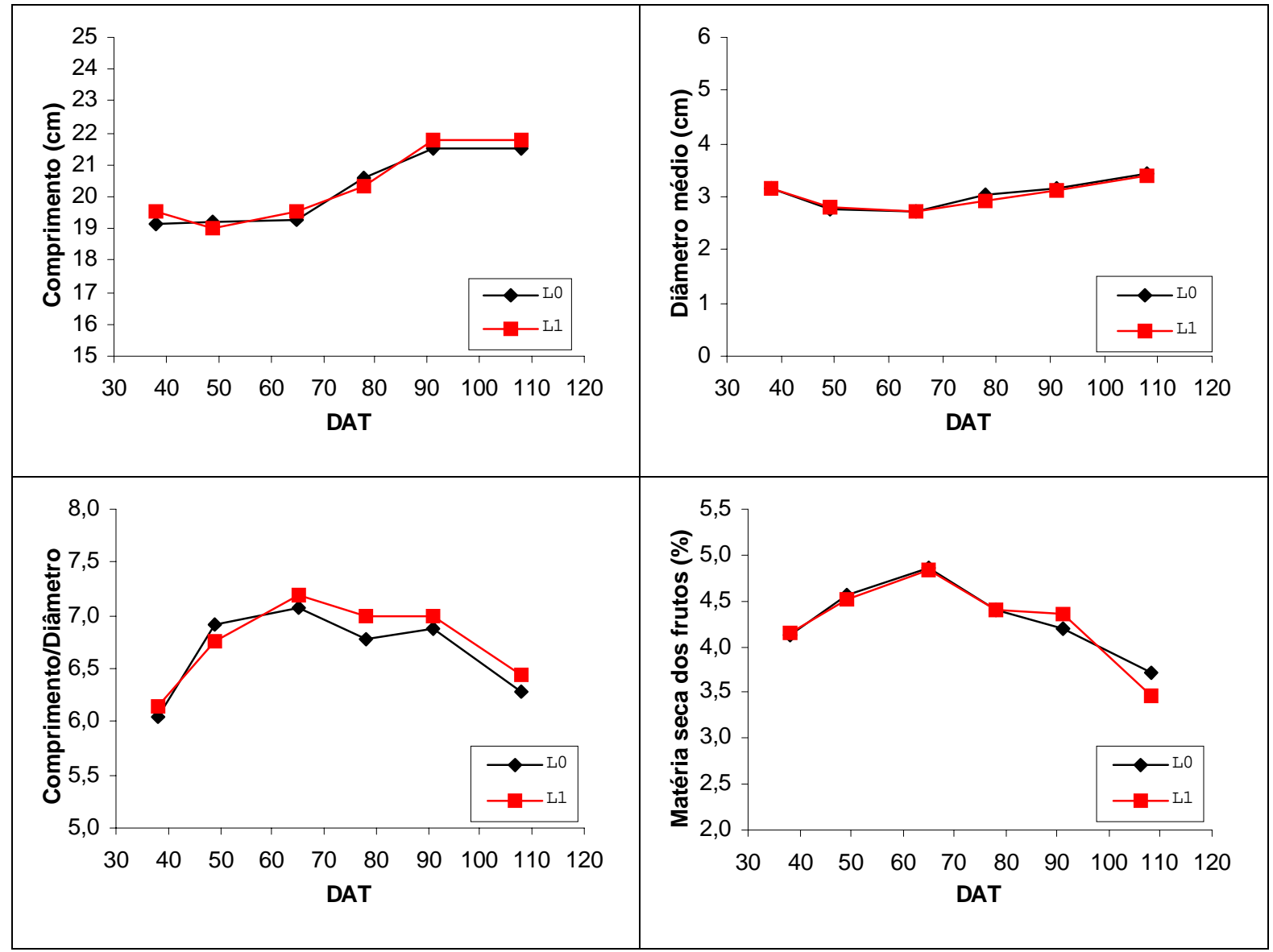

Figura 25. Características dos frutos para cada lâmina de irrigação. 


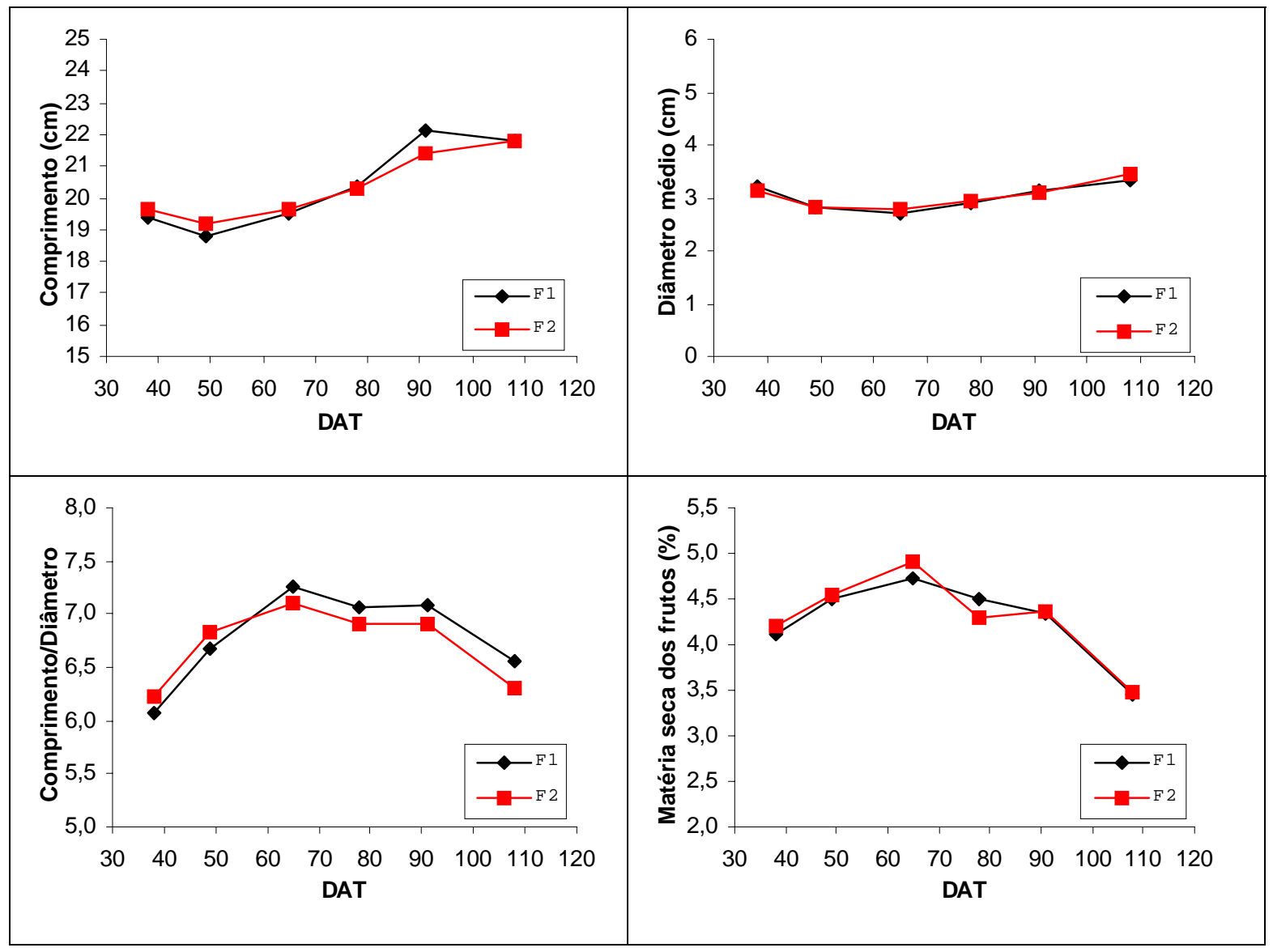

Figura 26. Características dos frutos para cada frequência de aplicação da lâmina L1. 
Tabela 13. Resumo da ANAVA e médias para o comprimento, diâmetro, relação comprimento/diâmetro e porcentagem de matéria seca dos frutos, para cada salinidade da água, lâmina de irrigação e frequência de aplicação da lâmina L1.

\begin{tabular}{|c|c|c|c|c|}
\hline \multirow[b]{2}{*}{ Fator } & \multicolumn{4}{|c|}{ Estatística F } \\
\hline & $\begin{array}{c}\text { Comprimento } \\
(\mathrm{cm})\end{array}$ & $\begin{array}{c}\text { Diâmetro } \\
(\mathrm{cm})\end{array}$ & Comp/Diâm & $\begin{array}{c}\text { Mat. seca } \\
(\%)\end{array}$ \\
\hline - Níveis de salinidade (S) & 0,84 & 2,42 & 0,99 & 0,60 \\
\hline Linear & 1,33 & 3,98 & 1,99 & 1,95 \\
\hline Quadr. & 0,35 & 0,85 & 0,001 & 0,004 \\
\hline - Lâmina (L) & 0,48 & 1,89 & 1,60 & 0,04 \\
\hline - Lâmina (L)/Frequência (F) & 0,27 & 1,96 & 1,24 & 0,77 \\
\hline \multirow[t]{2}{*}{ - Interação (S x LF) } & 0,69 & 2,19 & 1,75 & 0,42 \\
\hline & \multicolumn{4}{|c|}{ Valores médios } \\
\hline \multicolumn{5}{|l|}{ - Níveis de salinidade (S) } \\
\hline S1 & 20,42 & 3,02 & 6,77 & 4,25 \\
\hline S2 & 20,23 & 3,02 & 6,72 & 4,28 \\
\hline $\mathrm{S} 3$ & 20,20 & 3,07 & 6,67 & 4,34 \\
\hline \multicolumn{5}{|l|}{ - Lâmina (L) } \\
\hline L0 & 20,21 & 3,05 & 6,67 & 4,29 \\
\hline L1 & 20,32 & 3,03 & 6,75 & 4,30 \\
\hline \multicolumn{5}{|l|}{ - Lâmina (L)/Frequência (F) } \\
\hline $\mathrm{L} 1 \mathrm{~F} 1$ & 20,30 & 3,01 & 6,78 & 4,28 \\
\hline L1F2 & 20,34 & 3,04 & 6,71 & 4,32 \\
\hline
\end{tabular}

\subsubsection{Concentração mineral nas folhas e frutos de pepino e fertilidade do solo}

De acordo com Smith (1962) o teor dos nutrientes na planta deve estar contido dentro de uma faixa de concentração, a qual compreende um limite mínimo e um máximo. Malavolta et al. (1977) afirma que, por ocasião da absorção dos nutrientes, pode existir efeitos de antagonismo, sinergismo ou inibição de um nutriente sobre o outro. Portanto, os problemas de fertilidade do solo e nutrição das plantas geralmente são acentuados sob condições salinas devido à concentração de alguns íons específicos, podendo estes provocar fitotoxidez como também um desequilíbrio nutricional.

Papadopoulos (1994) afirma que uma planta de pepino bem nutrida apresenta o caule grosso (aproximadamente 1,5 cm), folhas grandes e verde-escuras e um grande número de frutos com crescimento rápido (intervalo de 7 dias entre o pegamento da flor 
e a colheita). Na Tabela 14 estão apresentadas as faixas ótimas de concentração de macro e micronutrientes em folhas de pepino, segundo alguns autores (Laboratório de Nutrição Mineral de Plantas - ESALQ/USP; Papadopoulos, 1994; Vetanovetz, 1996).

Tabela 14. Faixas ótimas de concentração de nutrientes em folhas de pepino, segundo alguns autores.

\begin{tabular}{c|c|c|c}
\hline \hline Nutriente & LNMP* & Papadopoulos (1994) & Vetanovetz (1996) \\
\hline \hline Macronutrientes & \multicolumn{3}{c}{$(\%)$} \\
$\mathrm{N}$ & $4,5-6,0$ & $3,0-6,0$ & $2,5-4,5$ \\
$\mathrm{P}$ & $0,3-1,2$ & $0,3-1,3$ & $0,4-0,8$ \\
$\mathrm{~K}$ & $3,5-5,0$ & $3,5-5,0$ & $6,0-10,0$ \\
$\mathrm{Ca}$ & $1,5-3,5$ & $0,5-5,0$ & $1,5-3,0$ \\
$\mathrm{Mg}$ & $0,3-1,0$ & $0,35-0,70$ & $0,5-1,5$ \\
$\mathrm{~S}$ & $0,4-0,7$ & - & - \\
\hline Micronutrientes & \multicolumn{4}{c}{$\left(\mathrm{mg} \cdot \mathrm{kg}^{-1}\right)$} \\
$\mathrm{B}$ & $25-60$ & $30-120$ \\
$\mathrm{Cu}$ & $7-20$ & $8-20$ & $40-120$ \\
$\mathrm{Fe}$ & $50-300$ & $100-300$ & $100-420$ \\
$\mathrm{Mn}$ & $50-300$ & $50-250$ & $100-300$ \\
$\mathrm{Zn}$ & $25-100$ & $40-100$ & $90-150$ \\
\hline
\end{tabular}

* Laboratório de Nutrição Mineral de Plantas - ESALQ/USP. Valores fornecidos juntamente com os resultados das análises foliares.

Pela Tabela 15, observa-se que os teores de macronutrientes no solo não apresentou uma tendência definida com o aumento da salinidade da água de irrigação. De maneira geral, os teores se apresentaram como altos e muito altos para todos os fatores envolvidos, indicando que a cultura recebeu quantidades suficientes de todos os nutrientes. Devido aos sais utilizados, era esperado que os teores de $\mathrm{Ca}, \mathrm{Mg}$ e S-SO4 aumentassem com os níveis de salinidade, pois a quantidade destes nutrientes aplicada via água de irrigação foi proporcional ao aumento de salinidade, o que não foi observado. 
Tabela 15. Teores de macro e micronutrientes e PST no solo para cada salinidade da água, lâmina de irrigação e frequência de aplicação da lâmina L1.

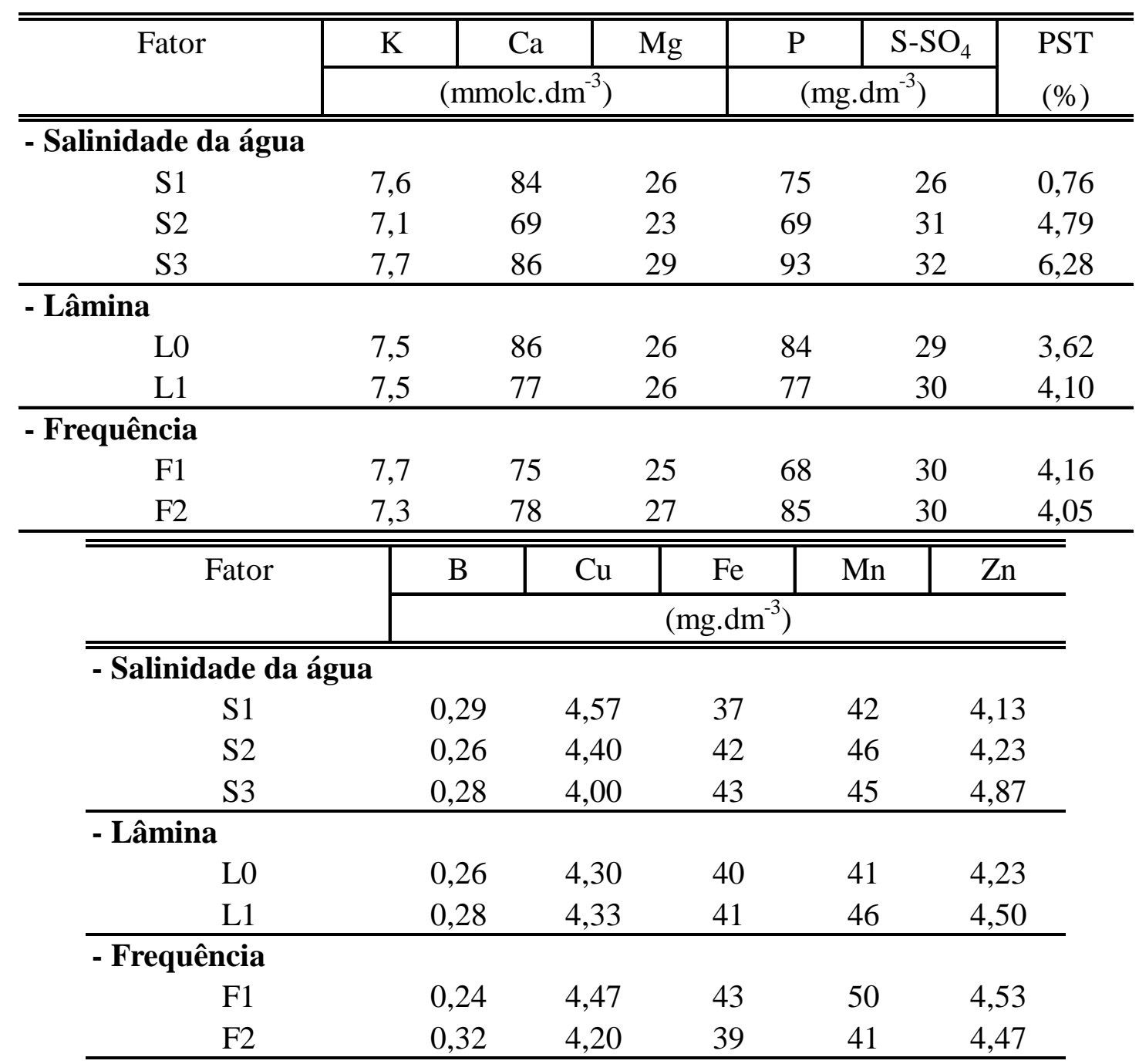

Comparando-se os valores da análise de solo realizada no final do período de cultivo (Tabela 15) com a análise no início (Tabela 1), verifica-se que os teores de K, $\mathrm{Ca}, \mathrm{P}$ e $\mathrm{S}_{-} \mathrm{SO}_{4}$ aumentaram consideravelmente, independente do tratamento utilizado, indicando que os níveis destes nutrientes na água de irrigação foram maiores do que os requeridos pela cultura. De acordo com a recomendação de adubação para pepino em campo aberto, apresentada por Cañizares (1998), os teores de P e K no solo são considerados altos para níveis maiores que $60 \mathrm{mg} \mathrm{dm}^{-3}$ e $3,0 \mathrm{mmolc} . \mathrm{dm}^{-3}$, respectivamente. Principalmente para o $\mathrm{K}$, os níveis no solo foram muito além do 
recomendado, podendo-se atribuir o pequeno aumento da salinidade do solo verificada para as parcelas irrigadas com a água S1 à aplicação excessiva de fertilizantes potássicos, principalmente. Verifica-se que o teor de $M g$ no solo não aumentou do início para o final do ciclo da cultura para as águas S1 e S2, apresentando pequeno aumento para S3, embora a quantidade aplicada neste último tenha sido bastante superior à dos demais.

A porcentagem de sódio trocável (PST) aumentou proporcionalmente à salinidade da água de irrigação, não apresentando grandes variações para as diferentes lâminas e frequência de aplicação de L1, concordando com dados obtidos por Medeiros (1998).

Os teores de micronutrientes no solo também apresentaram comportamento variado dentro dos fatores, sendo que $\mathrm{Fe}$ e $\mathrm{Cu}$ foram os que apresentaram maiores aumentos, enquanto que B e Mn diminuíram. Os teores de $\mathrm{Zn}$ não apresentaram grandes variações, apresentando valores considerados altos desde o início do experimento. Teores de $\mathrm{Cu}$ e $\mathrm{Zn}$ acima de 1,0 e 0,5 mg. $\mathrm{dm}^{-3}$, respectivamente, são considerados altos para a cultura do pepino.

Os teores de macro e micronutrientes nas folhas de pepino para cada fator envolvido encontram-se na Tabela 16. De maneira geral, não foram verificadas grandes variações para nenhum dos fatores. Observa-se que o teor de Na nas folhas foi maior para $\mathrm{S} 2$ e $\mathrm{S} 3$ em relação a $\mathrm{S} 1$, devido à adição de $\mathrm{NaCl}$ nestas águas para elevar a salinidade, o que também foi observado por Sonneveld \& Voogt (1978). Os teores de $\mathrm{Mg}, \mathrm{Ca}$ e S não apresentaram grandes variações com o aumento destes nutrientes na água de irrigação, da mesma forma que ocorreu para a análise de fertilidade do solo.

Pela Tabela 17, verifica-se que os teores da maioria dos nutrientes apresentou valores dentro de um limite ótimo para as diferentes águas de irrigação, variando em alguns casos de acordo com a recomendação dos diferentes autores. Deve-se salientar que não foram observados sintomas de deficiência e toxidez nas plantas em campo, sendo que isso só acontece quando as concentrações dos nutrientes atingem valores extremamente baixos ou altos. Os desvios encontrados em relação aos teores ótimos não foram suficientes para alterarem a fisiologia da planta ao ponto destas apresentarem 
sintomas visíveis de deficiência ou toxidez, embora em alguns casos, como para o nutriente cobre, os teores foliares tenham sido muito acima do recomendado, variando de 2,5 a 5,9 vezes, dependendo da recomendação considerada.

Tabela 16. Teores de macro e micronutrientes e sódio nas folhas de pepino no final do ciclo da cultura para cada salinidade da água, lâmina de irrigação e frequência de aplicação da lâmina L1.

\begin{tabular}{|c|c|c|c|c|c|c|c|}
\hline \multirow{2}{*}{$\begin{array}{ll}\text { Fator } \\
\end{array}$} & $\mathrm{N}$ & $\overline{\mathrm{P}}$ & $\overline{\mathrm{K}}$ & $\overline{\mathrm{Ca}}$ & $\mathrm{Mg}$ & $\overline{\mathrm{S}}$ & \multirow{2}{*}{$\begin{array}{c}\mathrm{Na} \\
\left(\mathrm{mg}^{\mathrm{kg}} \mathrm{kg}^{-1}\right)\end{array}$} \\
\hline & \multicolumn{6}{|c|}{$(\%)^{1}$} & \\
\hline \multicolumn{8}{|c|}{ - Salinidade da água } \\
\hline S1 & 5,02 & 0,55 & 3,01 & 2,17 & 0,45 & 0,52 & 137 \\
\hline S2 & 5,04 & 0,64 & 3,11 & 1,74 & 0,46 & 0,49 & 187 \\
\hline S3 & 4,84 & 0,65 & 3,42 & 2,01 & 0,45 & 0,48 & 173 \\
\hline \multicolumn{8}{|l|}{ - Lâmina } \\
\hline L0 & 5,07 & 0,66 & 3,03 & 1,88 & 0,43 & 0,49 & 173 \\
\hline L1 & 4,91 & 0,60 & 3,25 & 2,01 & 0,46 & 0,50 & 162 \\
\hline \multicolumn{8}{|l|}{ - Frequência } \\
\hline $\mathrm{F} 1$ & 4,64 & 0,60 & 3,32 & 1,67 & 0,43 & 0,49 & 153 \\
\hline $\mathrm{F} 2$ & 5,18 & 0,59 & 3,19 & 2,36 & 0,50 & 0,52 & 170 \\
\hline \multirow[t]{2}{*}{ Fator } & & $\mathrm{B}$ & $\mathrm{Cu}$ & $\mathrm{Fe}$ & $\mathrm{Mn}$ & & $\mathrm{Zn}$ \\
\hline & \multicolumn{7}{|c|}{$\left(\mathrm{mg} \cdot \mathrm{kg}^{-1}\right)^{2}$} \\
\hline \multicolumn{8}{|c|}{ - Salinidade da água } \\
\hline S1 & & 56 & 64 & 274 & 130 & & 103 \\
\hline S2 & & 67 & 60 & 257 & 115 & & 108 \\
\hline S3 & & 71 & 69 & 278 & 109 & & 103 \\
\hline \multicolumn{8}{|l|}{ - Lâmina } \\
\hline L0 & & 61 & 66 & 261 & 133 & & 105 \\
\hline L1 & & 66 & 64 & 275 & 110 & & 105 \\
\hline \multicolumn{8}{|l|}{ - Frequência } \\
\hline $\mathrm{F} 1$ & & 67 & 67 & 268 & 107 & & 107 \\
\hline F2 & & 66 & 61 & 281 & 114 & & 103 \\
\hline
\end{tabular}


Tabela 17. Classificação da concentração de nutrientes nas folhas de pepino de acordo com os níveis ótimos recomendados por alguns autores, em função da salinidade da água de irrigação.

\begin{tabular}{|c|c|c|c|}
\hline Nutriente & LNMP* & Papadopoulos (1994) & Vetanovetz (1996) \\
\hline \multicolumn{4}{|l|}{ Macronutrientes } \\
\hline $\mathrm{N}$ & $\mathrm{M}, \mathrm{M}, \mathrm{M}$ & $\mathrm{M}, \mathrm{M}, \mathrm{M}$ & $\mathrm{A}, \mathrm{A}, \mathrm{A}$ \\
\hline $\mathrm{P}$ & $\mathrm{M}, \mathrm{M}, \mathrm{M}$ & $\mathrm{M}, \mathrm{M}, \mathrm{M}$ & $\mathrm{M}, \mathrm{M}, \mathrm{M}$ \\
\hline $\mathrm{K}$ & $\mathrm{B}, \mathrm{B}, \mathrm{B}$ & $\mathrm{B}, \mathrm{B}, \mathrm{B}$ & $\mathrm{B}, \mathrm{B}, \mathrm{B}$ \\
\hline $\mathrm{Ca}$ & $\mathrm{M}, \mathrm{M}, \mathrm{M}$ & $\mathrm{M}, \mathrm{M}, \mathrm{M}$ & $\mathrm{M}, \mathrm{M}, \mathrm{M}$ \\
\hline $\mathrm{Mg}$ & $\mathrm{M}, \mathrm{M}, \mathrm{M}$ & $\mathrm{M}, \mathrm{M}, \mathrm{M}$ & $\mathrm{M}, \mathrm{M}, \mathrm{M}$ \\
\hline$S$ & $\mathrm{M}, \mathrm{M}, \mathrm{M}$ & - & - \\
\hline \multicolumn{4}{|l|}{ Micronutrientes } \\
\hline $\mathrm{B}$ & $\mathrm{M}, \mathrm{A}, \mathrm{A}$ & $\mathrm{M}, \mathrm{M}, \mathrm{M}$ & $\mathrm{M}, \mathrm{M}, \mathrm{M}$ \\
\hline $\mathrm{Cu}$ & $\mathrm{A}, \mathrm{A}, \mathrm{A}$ & $\mathrm{A}, \mathrm{A}, \mathrm{A}$ & $\mathrm{A}, \mathrm{A}, \mathrm{A}$ \\
\hline $\mathrm{Fe}$ & $\mathrm{M}, \mathrm{M}, \mathrm{M}$ & $\mathrm{M}, \mathrm{M}, \mathrm{M}$ & $\mathrm{M}, \mathrm{M}, \mathrm{M}$ \\
\hline Mn & $\mathrm{M}, \mathrm{M}, \mathrm{M}$ & $\mathrm{M}, \mathrm{M}, \mathrm{M}$ & $\mathrm{M}, \mathrm{M}, \mathrm{M}$ \\
\hline $\mathrm{Zn}$ & $\mathrm{A}, \mathrm{A}, \mathrm{A}$ & $\mathrm{A}, \mathrm{A}, \mathrm{A}$ & $\mathrm{M}, \mathrm{M}, \mathrm{M}$ \\
\hline
\end{tabular}

Os teores de macro e micronutrientes e sódio nos frutos encontram-se na Tabela 18. Observa-se que os teores de N, P, K, Ca, Mg e Na tendem a aumentar com o aumento da salinidade da água de irrigação e a reduzir com o aumento da lâmina relativa de irrigação, exceto para $\mathrm{N}$ e $\mathrm{Na}$, enquanto que os teores de micronutrientes não apresentaram uma tendência definida. Como não se dispõe de dados sobre a faixa ótima de concentração mineral nos frutos, não é possível avaliar a adequabilidade dos dados observados nos diferentes tratamentos. 
Tabela 18. Teores de macro e micronutrientes e sódio nos frutos de pepino no final do ciclo da cultura para cada salinidade da água, lâmina de irrigação e frequência de aplicação da lâmina L1.

\begin{tabular}{|c|c|c|c|c|c|c|c|}
\hline \multirow[t]{2}{*}{ Fator } & $\mathrm{N}$ & $\mathrm{P}$ & $\overline{\mathrm{K}}$ & $\mathrm{Ca}$ & $\mathrm{Mg}$ & $\bar{S}$ & \multirow{2}{*}{$\begin{array}{c}\mathrm{Na} \\
\left(\mathrm{mg} \cdot \mathrm{kg}^{-1}\right.\end{array}$} \\
\hline & \multicolumn{6}{|c|}{$(\%)^{1}$} & \\
\hline \multicolumn{8}{|c|}{ - Salinidade da água } \\
\hline S1 & 4,14 & 0,49 & 4,34 & 0,31 & 0,28 & 0,41 & 267 \\
\hline S2 & 4,13 & 0,54 & 5,67 & 0,36 & 0,30 & 0,41 & 300 \\
\hline S3 & 4,28 & 0,55 & 6,07 & 0,36 & 0,32 & 0,40 & 337 \\
\hline \multicolumn{8}{|l|}{ - Lâmina } \\
\hline L0 & 4,17 & 0,62 & 5,41 & 0,37 & 0,32 & 0,41 & 273 \\
\hline L1 & 4,19 & 0,48 & 5,33 & 0,33 & 0,29 & 0,40 & 315 \\
\hline \multicolumn{8}{|l|}{ - Frequência } \\
\hline F1 & 4,21 & 0,56 & 5,56 & 0,35 & 0,30 & 0,42 & 337 \\
\hline F2 & 4,18 & 0,40 & 5,11 & 0,32 & 0,28 & 0,39 & 293 \\
\hline \multirow[t]{2}{*}{ Fator } & & $\overline{\mathrm{B}}$ & $\overline{\mathrm{Cu}}$ & $\mathrm{Fe}$ & $\overline{\mathrm{Mn}}$ & & $\overline{\mathrm{Zn}}$ \\
\hline & \multicolumn{7}{|c|}{$\left(\mathrm{mg} \cdot \mathrm{kg}^{-1}\right)^{2}$} \\
\hline \multicolumn{8}{|c|}{ - Salinidade da água } \\
\hline S1 & & 17 & 55 & 116 & 38 & & 248 \\
\hline S2 & & 29 & 60 & 120 & 42 & & 319 \\
\hline S3 & & 15 & 59 & 119 & 42 & & 254 \\
\hline \multicolumn{8}{|l|}{ - Lâmina } \\
\hline L0 & & 14 & 61 & 131 & 49 & & 317 \\
\hline L1 & & 23 & 56 & 112 & 36 & & 252 \\
\hline \multicolumn{8}{|l|}{ - Frequência } \\
\hline F1 & & 18 & 61 & 124 & 40 & & 293 \\
\hline $\mathrm{F} 2$ & & 29 & 52 & 100 & 33 & & 210 \\
\hline
\end{tabular}

\subsection{Experimento II}

Quando as frações de lixiviação utilizadas na irrigação não são suficientes para impedir o aumento do teor de sais no solo durante o ciclo de uma cultura, faz-se necessária a redução da salinidade do solo até um nível tolerado pela cultura a ser implantada através da lavagem de recuperação (Rhoades et al., 1992). 
A salinidade do solo antes da recuperação e a lâmina de lavagem utilizada estão apresentadas na Tabela 19. Observa-se que a lâmina média aplicada por gotejamento variou de 71 a 203 mm e para inundação de 170 a 297 mm.

Tabela 19. Salinidade do solo antes da recuperação e lâmina de lavagem aplicada para cada método de aplicação e lâmina relativa de lavagem.

\begin{tabular}{c|ccc|c}
\hline \hline \multirow{2}{*}{$\begin{array}{c}\text { Lâmina relativa } \\
\text { de lavagem }\end{array}$} & \multicolumn{2}{|c|}{ Salinidade do solo $\left(\mathrm{dS} \cdot \mathrm{m}^{-1}\right)$} & \multicolumn{2}{c}{ Lâmina de lavagem (mm) } \\
\cline { 2 - 5 } & Gotejamento & Inundação & Gotejamento & Inundação \\
\hline \hline D1 & 2,49 & 2,95 & 71 & 170 \\
D2 & 2,52 & 2,58 & 108 & 222 \\
D3 & 3,11 & 2,33 & 203 & 297 \\
\hline
\end{tabular}

Verifica-se pela Figura 27 que a salinidade do solo foi reduzida após a lavagem, apresentando maiores reduções para o método de aplicação por gotejamento, sendo que a salinidade do solo diminuiu com o aumento da lâmina relativa de lavagem. Por outro lado, quando a aplicação foi realizada por inundação, a redução da salinidade do solo foi menos afetada pelo aumento da lâmina relativa de lavagem.

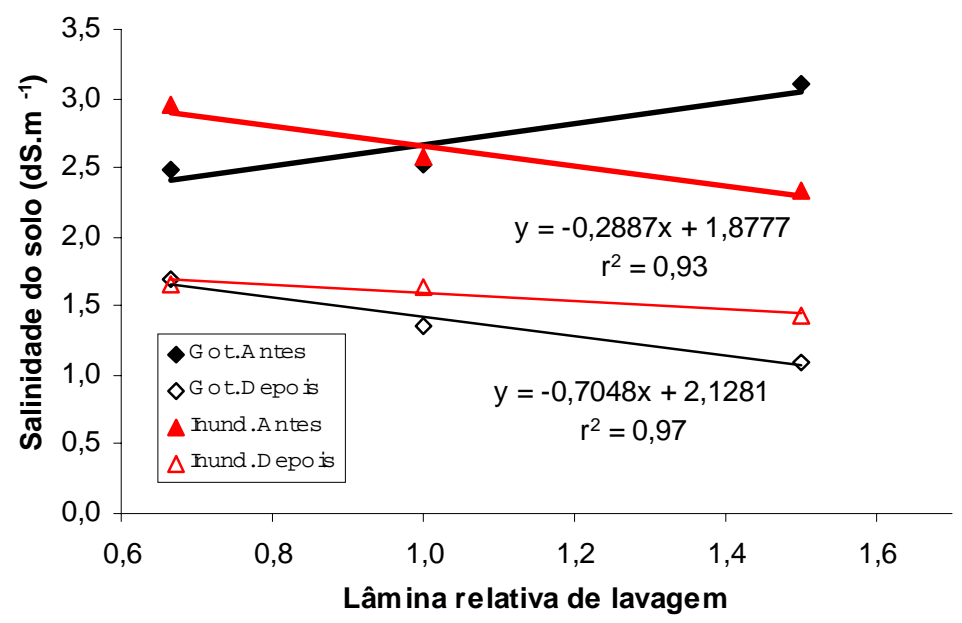

Figura 27. Salinidade do solo antes e depois da aplicação das lâminas de lixiviação por gotejamento e inundação utilizando diferentes lâminas relativas de lavagem. 
A análise estatística, apresentada na Tabela 20, demonstrou que a salinidade final do solo (CEF), a redução da salinidade (CEI-CEF) e a relação CEF/CEI reduziram linearmente com o aumento da lâmina relativa de lavagem quando a recuperação foi realizada por gotejamento, não apresentando diferença significativa para a aplicação por inundação. Além disso, a lâmina relativa D3 proporcionou uma salinidade final significativamente menor para gotejamento, como também uma menor relação CEF/CEI, do que a aplicação por inundação, sendo que a redução na salinidade não apresentou diferença significativa entre os métodos de aplicação, embora o valor para gotejamento tenha sido 2,2 vezes menor do que para a aplicação por inundação.

Tabela 20. Resumo da ANAVA e médias da salinidade do solo após a recuperação (CEF), redução da salinidade (CEI-CEF), relação entre a salinidade final e a inicial (CEF/CEI) e coeficiente k da equação de Rhoades \& Loveday (1990) para os diferentes métodos de aplicação da lâmina e lâminas relativas de lavagem.

\begin{tabular}{|c|c|c|c|c|c|c|c|c|}
\hline \multirow{3}{*}{ Fator } & \multicolumn{8}{|c|}{ Estatística $\mathbf{F}$} \\
\hline & \multicolumn{2}{|c|}{ CEF } & \multicolumn{2}{|c|}{ CEI-CEF } & \multicolumn{2}{|c|}{ CEF/CEI } & \multicolumn{2}{|c|}{ Coeficiente $\mathrm{k}$} \\
\hline & Got. & Inund. & Got. & Inund. & Got. & Inund. & Got. & \begin{tabular}{|l|} 
Inund. \\
\end{tabular} \\
\hline - Lâm. Lav. & $15,1^{*}$ & 0,52 & $\begin{array}{ll}4,78 \\
\end{array}$ & 0,72 & $10,99^{*}$ & 0,25 & 3,07 & 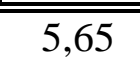 \\
\hline Linear & $29,29 * *$ & 0,96 & $9,43 *$ & 1,10 & $21,98^{*}$ & 0,24 & 6,10 & $11,07 *$ \\
\hline \multirow[t]{2}{*}{ Quadr. } & 0,92 & 0,07 & 0,14 & 0,35 & 0,001 & 0,26 & 0,04 & 0,22 \\
\hline & \multicolumn{8}{|c|}{ Valores médios $^{1}$} \\
\hline \multicolumn{9}{|l|}{ - Lâm. Lav. } \\
\hline D1 & $1,69 \mathrm{a}$ & $1,66 a$ & $0,79 a$ & $1,29 \mathrm{a}$ & $0,69 \mathrm{a}$ & $0,56 \mathrm{a}$ & $0,077 \mathrm{a}$ & $0,15 \mathrm{a}$ \\
\hline D2 & $1,36 \mathrm{a}$ & $1,63 \mathrm{a}$ & $1,15 \mathrm{a}$ & $0,95 \mathrm{a}$ & $0,56 \mathrm{a}$ & $0,63 \mathrm{a}$ & $0,089 \mathrm{~b}$ & $0,22 \mathrm{a}$ \\
\hline D3 & $1,09 b$ & $1,43 \mathrm{a}$ & $2,02 \mathrm{a}$ & $0,90 \mathrm{a}$ & $0,36 \mathrm{~b}$ & $0,62 \mathrm{a}$ & $0,103 \mathrm{~b}$ & $0,283 a$ \\
\hline
\end{tabular}

* Significativo ao nível de 0,05 de probabilidade pelo teste $\mathrm{F}$

** Significativo ao nível de 0,01 de probabilidade pelo teste $\mathrm{F}$

${ }^{1}$ Médias seguidas por letras diferentes nas linhas apresentam diferença significativa ao nível de 0,05 de probabilidade pelo teste de Tukey entre a aplicação por gotejamento e inundação, para cada variável analisada.

$\mathrm{Na}$ aplicação por inundação, a ausência de redução da salinidade com o acréscimo da lâmina de lavagem deve estar relacionada à baixa eficiência de lixiviação, pois o aumento da lâmina contribuiu para que a inundação se aproximasse mais da 
inundação contínua que, segundo Hoffman (1980), leva a uma redução significativa na eficiência de lavagem, devido ao fluxo preferencial que ocorre nesta condição.

Pela Figura 28, verifica-se que o coeficiente k apresentou valores que variaram de 0,08 a 0,10, estando estes bastante próximos ao recomendado por Hoffman (1980). Para a recuperação por inundação, os valores de $\mathrm{k}$ variaram de 0,15 a 0,28 com o aumento da lâmina aplicada, aproximando-se do valor recomendado para a aplicação por inundação contínua que é de 0,3 . O valor estimado do coeficiente $\mathrm{k}$ após a recuperação por gotejamento não apresentou variações estatisticamente significativas (Tabela 20) com o aumento da lâmina de lavagem, sendo que este apresentou aumento linear quando a recuperação foi realizada por inundação.

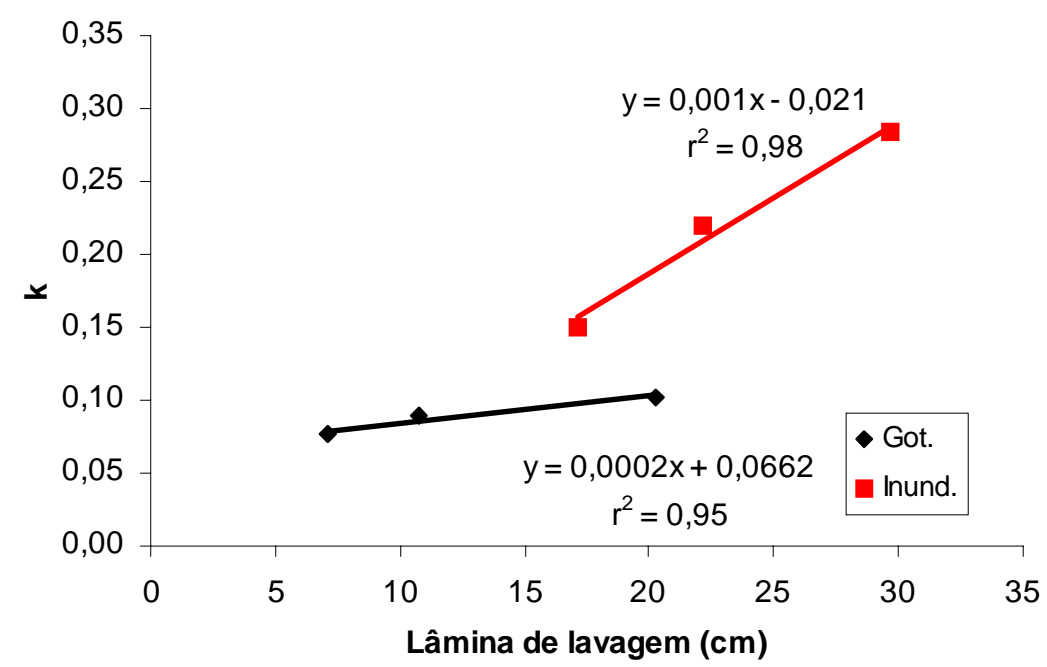

Figura 28. Valores do coeficiente k para os métodos de aplicação da lâmina de lavagem por gotejamento e inundação em função da lâmina aplicada.

Pela equação de regressão da CEF, apresentada na Figura 27, pode-se dizer que a lâmina relativa de lavagem e o valor do coeficiente k para reduzir a salinidade do solo para $1,5 \mathrm{dS} \cdot \mathrm{m}^{-1}$ devem ser de 0,9 e 0,1 para gotejamento e 1,3 e 0,2 para inundação, respectivamente. 


\section{CONCLUSÕES}

À partir dos resultados obtidos no presente trabalho, pode-se estabelecer as seguintes conclusões:

a) A salinidade da água de irrigação resultou na redução do número de frutos comerciais do pepino japonês, cultivar "Hokushin", enxertado sobre Cucurbita spp., híbrido Excite-Ikki, cultivado em ambiente protegido, sendo esta de 3,32\% para cada incremento de uma unidade de salinidade da água. As lâminas de irrigação (L0 = 1.ETc e L1 = 1,25.ETc) e frequências de aplicação de L1 (F1 = em todas as irrigações e F2 = quando a lâmina de irrigação acumulada em L0 alcançava $100 \mathrm{~mm}$ ) não afetaram a produtividade e nem os componentes de produção.

b) A redução no rendimento comercial e total foi de 2,99 e 2,83\% para o incremento de uma unidade de salinidade na água de irrigação, não representando diferenças estatisticamente significativas. A redução de produção, comercial e total, foi de 7,24 e $6,71 \%$ para o aumento de uma unidade na condutividade elétrica do extrato de saturação.

c) A altura das plantas, área foliar unitária, índice de área foliar e diâmetro do colo das plantas foram afetados pela salinidade da água, sendo que as diferentes lâminas de irrigação não apresentaram efeitos significativos sobre estas variáveis. As diferentes lâminas de irrigação, bem como o manejo de aplicação da lâmina L1 resultaram na redução do diâmetro do colo da planta, apresentando menor redução para a frequência F2 dentro do nível S1 de salinidade $\left(\mathrm{CE}=1,0 \mathrm{dS} \cdot \mathrm{m}^{-1}\right)$.

d) A salinidade do solo aumentou proporcionalmente com o aumento da concentração salina da água de irrigação, independente da lâmina de irrigação e da frequência de aplicação da lâmina L1. 
e) A salinidade da água de irrigação e a frequência F1 de aplicação da lâmina L1 proporcionaram uma redução no módulo do potencial mátrico, avaliado pontualmente nas profundidades de 15 e $30 \mathrm{~cm}$, bem como na média das profundidades. As lâminas de irrigação, bem como a associação lâmina/frequência, resultaram na diminuição do módulo do potencial mátrico medido a $30 \mathrm{~cm}$ e médio para as profundidades de 15 e $30 \mathrm{~cm}$, não afetando a umidade medida a $15 \mathrm{~cm}$ de profundidade.

f) A concentração de sódio nas folhas e frutos aumentou com o incremento da salinidade da água de irrigação, não sendo observadas grandes variações para os teores de macro e micronutrientes.

g) Para a recuperação do solo salinizado após o cultivo, a equação proposta por Rhoades \& Loveday (1990) apresentou resultados satisfatórios, devendo-se utilizar lâminas relativas de lavagem de 0,9 e 1,3 e coeficiente $\mathrm{k}$ de 0,1 e 0,2 para recuperação por gotejamento e inundação, respectivamente.

h) O comprimento, diâmetro, relação comprimento/diâmetro e porcentagem de matéria seca dos frutos não foi afetada pela salinidade da água, lâmina de irrigação e frequências de aplicação da lâmina L1.

i) Considerando uma perda de rendimento aceitável de $10 \%$ para o aumento de uma unidade de salinidade do solo, não foi possível determinar o limite de salinidade da água de irrigação à partir do qual o pepino enxertado reduz significativamente sua produção.

j) Quando a água utilizada na irrigação apresentar alto teor salino, deve-se realizar a lixiviação do excesso de sais do solo após um cultivo, antes de realizar um novo plantio, caso a salinidade do solo ultrapasse o limite tolerado pela cultura. 


\section{REFERÊNCIAS BIBLIOGRÁFICAS}

AYERS, R.S.; WESTCOT, D.W. Water quality for agriculture. Rome: FAO, 1985. 174 p. (FAO. Irrigation and Drainage Paper, 29 rev. 1)

BAILLE, A. Water status monitoring in greenhouse crops. Acta Horticulturae, v.304, p.15-27, 1992.

BAJWA, M.S.; JOSAN, A.S.; HIRA, G.S.; SINGH, N.T. Effect of sustained saline irrigation on soil salinity and crop yields. Irrigation Science, v.7, n.1, p.27-35, 1986.

BAR-YOSEF, B. Advances in fertigation. Advances in Agronomy, v.65, p.1-77, 1999.

BERNARDO, S. Manual de Irrigação. 6.ed. Viçosa: Imprensa Universitária, 1995. $657 \mathrm{p}$.

BERNSTEIN, L.; HAYWARD, H.E. Physiology of salt tolerance. Annual Review of Plant Physiology, v.9, p.25-46, 1958.

BEZERRA, F.M.L. Coeficientes de cultura e efeitos de déficits hídricos nos diferentes estádios fenológicos sobre a produção de batata (Solanum tuberosum, L.). Piracicaba, 1995. 131p. Tese (Doutorado) - Escola Superior de Agricultura "Luiz de Queiroz", Universidade de São Paulo.

BIGGAR, J.W.; ROLSTON, D.E.; NIELSEN, D.R. Transport of salts by water. California Agriculture, v.38, n.10, p.10-11, 1984.

BLANCO, F.F.; FOLEGATTI, M.V. Estimativa da evapotranspiração em estufa plástica utilizando dados meteorológicos externos. In: BALBUENA, R.H.; BENEZ, S.H.; JORAJURÍA, D. (Eds.) Avances en el manejo del suelo y agua en la ingeniería rural latinoamericana. La Plata: 1998. p.361-366. 
BLANCO, F.F.; FOLEGATTI, M.V. Salinização do solo em ambiente protegido sob fertirrigação. In: WORKSHOP DE FERTIRRIGAÇÃO, 1, Piracicaba, 1999. Resumos. Piracicaba: DER/ESALQ/USP, 1999. p.3-4.

BLANCO, F.F.; MEDEIROS, J.F.; FOLEGATTI, M.V. Produção da alface (Lactuca sativa L.) em ambiente protegido sob condições salinas. In: CONGRESSO BRASILEIRO DE ENGENHARIA AGRÍCOLA, 28, Pelotas, 1999. CDROM. Pelotas: 1999.

BRESLER, E.; McNEAL, B.L.; CARTER, D.L. Saline and sodic soils: principlesdynamics-modeling. Berlin: Springer-Verlag, 1982. 236p. (Advanced series in agricultural sciences, 10)

CALlEBAUT, M.; BADJI, M.; FEYEN, J. Response of some horticultural crops to irrigation in the semi-arid region of Tunisia. Scientia Horticulturae, v.26, n.4, p.279-291, 1985.

CAÑIZARES, K.A.L. A cultura do pepino. In: GOTO, R.; TIVELLI, S.W. (Org.) Produção de hortaliças em ambiente protegido: condições subtropicais. São Paulo: UNESP, 1998. cap.7, p.195-223.

CAÑIZARES, K.A.L.; GOTO, R. Crescimento e produção de híbridos de pepino em função da enxertia. Horticultura Brasileira, v.16, n.2, p.110-113, 1998.

CARLESSO, R. Absorção de água pelas plantas: água disponível versus extraível e a produtividade das culturas. Ciência Rural, v.25, n.1, p.183-188, 1995.

CARRIJO, O.A.; SILVA, W.L.C.; MAROUELLI, W.A.; SILVA, H.R. Tendências e desafios da fertirrigação no Brasil. In: FOLEGATTI, M.V. (Coord.) Fertirrigação: citrus, flores, hortaliças. Guaíba: Agropecuária, 1999. cap.1, p.155-169.

CASTILLA, N.; ELIAS, F.; FERERES, E. Evapotranspiracion de cultivos horticolas en invernadero en Almeria. Investigacion Agraria: Produccion y Proteccion Vegetal, v.5, n.1, p.117-125, 1990.

CHAPMAN, V.J. The salinity problem in general: its importance, and distribution with special reference to natural halophytes. In: POLJAKOF-MAYBER, A.; GALE, J. Plants in saline environments. New York: Springer-Verlag, 1975. p.6-24. 
CHARTZOULAKIS, K.; MICHELAKIS, N. Effects of different irrigation systems on growth and yield of greenhouse cucumber. Acta Horticulturae, v.278, p.237-243, 1990.

CHARTZOULAKIS, K.S. Effects of saline irrigation water on germination, growth and yield of greenhouse cucumber. Acta Horticulturae, v.287, p.327-334, 1990.

CHARTZOULAKIS, K.S. Photosynthesis, water relations and leaf growth of cucumber exposed to salt stress. Scientia Horticulturae, v.59, n.1, p.27-35, 1994.

CHOULIARAS, N.A.; MAVROMATIS, E. Nutritional conditions of cultures in greenhouses in Thessaly (Greece). Acta Horticulturae, v.287, p.221-227, 1990.

CRUCIANI, D.E.; MEDEIROS, J.F.; VILLA, S.T. Salinização de solo cultivado com feijão sob irrigação e lixiviação. In: CONGRESSO NACIONAL DE IRRIGAÇÃO E DRENAGEM, 11, Campinas, 1996. Anais. Campinas: FEC/FEAGRI/ABID, 1996. p.641-652.

DOORENBOS, J.; PRUITT, W.O. Guidelines for predicting crop water requirements. 2.ed. Rome: FAO, 1977. 179p. (FAO. Irrigation and Drainage Paper, 24)

ELIADES, G. Irrigation of greenhouse-grown cucumbers. Journal of Horticultural Science, v.63, n.2, p.235-239, 1988.

FARIAS, J.R.B.; BERGAMASCHI, H.; MARTINS, S.R. Evapotranspiração no interior de estufas plásticas. Revista Brasileira de Agrometeorologia, v.2, p.17-22, 1994.

FNP CONSULTORIA E COMÉRCIO. Agrianual 99: anuário da agricultura brasileira. São Paulo: Argos Comunicação, 1999. 521p.

FRANCOIS, L.E. Alfalfa management under saline conditions with zero leaching. Agronomy Journal, v.73, p.1042-1046, 1981.

FREITAS, A.A.; BEZERRA, F.M.I. Determinação da evapotranspiração máxima e real da melancia (Citrullus lanatus) var. "Crimson sweet". In: CONGRESSO BRASILEIRO DE ENGENHARIA AGRÍCOLA, 28, Pelotas, 1999. CD-ROM. Pelotas, 1999. 
FRIZZONE, J.A.; BOTREL, T.A.; DOURADO NETO, D. Aplicação de fertilizantes via água de irrigação. Piracicaba: ESALQ/DER, 1994. 35p. (Série Didática, 8)

GOMES, H.P. Engenharia de irrigação. João Pessoa: UFPB, 1994. 344p.

GORHAM, J. Sodium content of agricultural crops. In: PHILLIPS, C.J.C.; CHIY, P.C.

(Eds.) Sodium in agriculture. Canterbury: Chalcombe Publications, 1995. cap.2, p.17-32.

GORNAT, B.; GOLDBERG, D.; RIMON, D.; BEN-ASHER, J. The physiological effect of water quality and method of application on tomato, cucumber, and pepper. Journal of the American Society for Horticultural Science, v.98, n.2, p.202-205, 1973.

GOTO, R. Plasticultura nos trópicos: uma avaliação técnico-econômica. Horticultura Brasileira, v.15, suplemento, p.163-165, 1997.

HERNANDEZ, F.B.T. Efeitos da supressão hídrica nos aspectos produtivos e qualitativos da cultura do melão. Piracicaba, 1995. 75p. Tese (Doutorado) - Escola Superior de Agricultura “Luiz de Queiroz”, Universidade de São Paulo.

HOFFMAN, G.J. Guidelines for reclamation of salt-affected soils. In: INTERAMERICAN SALINITY WATER MANAGEMENT TECHNOLOGY CONFERENCE, Juarez, 1980. Proceedings. Juarez: 1980. p.49-64.

HOFFMAN, G.J.; RHOADES, J.D.; LETEY, J.; SHENG, F. Salinity management. In: HOFFMAN, G.J.; HOWELL, T.A.; SOLOMON, K.H. (Ed.) Management of farm irrigation systems. St. Joseph: ASAE, Pamela De-Vore-Hansen, 1982. cap.18, p.667-715, 1992. (ASAE Monograph, 9).

HOFFMAN, G.J.; VAN GENUCHTEN, M.Th. Soil properties and efficient water use: water management for salinity control. In: TAYLOR, H.M.; JORDAN, W.R.; SINCLAIR, T.R. (Eds.) Limitations to efficient water use in crop production. Madison: ASA/CSSA/SSSA, 1983. p.73-85.

HSIAO, T.C. Additive and interactive effects of soil salinity and water regimes on crop-growth responses and osmoregulation. In: LETEY, J. (Ed.) Soil and plant interactions with salinity: Kearney Foundation; five year report, 1980- 
85. Berkeley: University of California, Division of Agriculture and Natural Resources, Agricultural Experiment Station, 1985. p.18-21.

JANOWSKI, G.; SKAPSKI, H. Hydro-peat method for greenhouse cucumber production. Acta Horticulturae, n.156, p.27-33, 1985. /Resumo 2424 em Horticultural Abstracts, v.56, n.1, p.253, Jan. 1986/

JONES, R.W.; PIKE JR., L.M.; YOURMAN, L.F. Salinity influences cucumber growth and yield. Journal of the American Society for Horticultural Science, v.114, n.4, p.547-551, 1989.

KHAN, A.A.; YITAYEW, M.; WARRICK, A.W. Field evaluation of water and solute distribution from a point source. Journal of Irrigation and Drainage Engineering, v.122, n.4, p.221-227, 1996.

KLEPPER, B. Root growth and water uptake. In: STEWART, D.R. \& NIELSEN, D.R. (Eds.) Irrigation of agricultural crops. Madison: ASA/CSSA/SSSA, 1990. p.282322.

LAKSHMANAN, R.; TAJUDDIN, E. Irrigation schedule for pumpkin (Cucurbita moschata) and oriental pickling melon (Cucumis melo) with can evaporimeter. Indian Journal of Agricultural Sciences, v.60, n.3, p.206-208, 1990.

LÄUCHLI, A.; EPSTEIN, E. Mechanisms of salt tolerance in plants. California Agriculture, v.38, n.10, p.18-20, 1984.

LÄUCHLI, A.; EPSTEIN, E. Plant responses to saline and sodic conditions. In: TANJI, K.K. (Ed.) Agricultural salinity assessment and management. New York: ASCE, 1990. cap.6, p.113-137.

LIEBIG, H.P. Model for cucumber growth and yield. I. Raising the crop under low temperature regimes. Acta Horticulturae, n.156, p.127-137, 1985. /Resumo 2417 em Horticultural Abstracts, v.56, n.1, p.252, Jan. 1986/

LIMA, L.A. Efeitos dos sais no solo e na planta. In: GHEYI, H.R.; QUEIROZ, J.E.; MEDEIROS, J.F. (Eds.) Manejo e controle da salinidade na agricultura irrigada. Campina Grande: UFPB/SBEA, 1997. cap.4, p.113-136.

LIMA, R.D’Arc.; DIAS, W.P.; CASTRO, J.M.C. Doenças causadas por nematóides em cucurbitáceas. Informe agropecuário, v.17, n.182, p.57-59, 1995. 
LOOMIS, E.L.; CRANDALL, P.C. Water consumption of cucumbers during vegetative and reproductive stages of growth. Journal of American Society of Horticultural Science, v.102, n.2, p.124-127, 1977.

LYLE, C.W.; MEHANNI, A.H.; REPSYS, A.P. Leaching rates under a perennial pasture irrigated with saline water. Irrigation Science, v.7, n.4, p.277-286, 1986.

MAAS, E.V.; HOFFMAN, G.J. Crop salt tolerance - current assessment. Journal of the Irrigation and Drainage Division, v.103, n.IR2, p.115-134, 1977.

MALAVOLTA, E.; VITTI, G.C.; OLIVEIRA, S.A. Avaliação do estado nutricional das plantas: princípios e aplicações. 2.ed. Piracicaba: POTAFOS, 1997. 201p.

MANNINI, P. Effects of different irrigation scheduling and systems on yield response of melon and cucumber. Acta Horticulturae, n.228, p.155-162, 1988.

MAROUELLI, W.A.; SILVA, H.R.; SILVA, W.L.C. Manejo da irrigação em hortaliças. Brasília: EMBRAPA/CNPH, 1986. 12p. (EMBRAPA/CNPH. Circular Técnica, 2)

MARTÍNEZ-RAYA, A.; CASTILLA, N. Evapotranspiracion del pimiento en invernadero en Almeria. ITEA: Produccion Vegetal, n.85, p.57-62, 1989.

MARTINS, G. Uso de casa-de-vegetação com cobertura plástica na tomaticultura de verão. Jaboticabal, 1992. 65p. Tese (Doutorado) - Faculdade de Ciências Agrárias e Veterinária, Universidade Estadual Paulista.

MEDEIROS, J.F. Manejo da água de irrigação salina em estufa cultivada com pimentão. Piracicaba, 1998. 152p. Tese (Doutorado) - Escola Superior de Agricultura "Luiz de Queiroz”, Universidade de São Paulo.

MEDEIROS, J.F.; GHEYI, H.R. A qualidade da água de irrigação. Campina Grande: UFPB, 1994. 60 p.

MEDEIROS, J.F.; PEREIRA, F.A.C.; FOLEGATTI, M.V.; PEREIRA, A.R.; VILLA NOVA, N.A. Comparação entre a evaporação em tanque Classe-A padrão e em minitanque, instalados em estufa e estação meteorológica. In: CONGRESSO BRASILEIRO DE AGROMETEOROLOGIA, 10, Piracicaba, 1997. Anais. Piracicaba: SBA, 1997. p.228-230. 
MEIRI, A.; KAMBUROV, J.; SHALHEVET, J. Transpiration effects on leaching fractions. Agronomy Journal, v.69, n.5, p.779-782, 1977.

MEIRI, A.; SHALHEVET, J. Pepper plant response to irrigation water quality and timing of leaching. In: HADA, A.; SWARTZENDRUBER, D.; RIJTEMA, P.E.; FUCHS, M.; YARON, B. Physical aspects of soil water and salts in ecosystems. Berlin: Springer-Verlag, 1973. p.284-297. (Ecological Studies, 4)

MEIRI, A.; LAUTER, D.J.; SHARABANI, N. Shoot growth and fruit development of muskmelon under saline and non-saline soil water deficit. Irrigation Science, v.16, n.1, p.15-21, 1995.

MONTERO, J.I.; CASTILlA, N.; GUTIERREZ de RAVÉ, E.; BRETONES, F. Climate under plastic in the Almeria area. Acta Horticulturae, n.170, p.227-234, 1985.

NOGUEIRA, F.D.; LIMA, L.A.; GUIMARÃES, P.T.G. Fertirrigação para o cafeeiro. Informe Agropecuário, v.19, n.193, p.82-91, 1998.

ODA, M. New grafting methods for fruit-bearing vegetables in Japan. Japan Agricultural Research Quarterly, v.29, n.3, p.187-194, 1995.

ODA, M.; TSUJI, K.; SASAKI, H. Effect of hypocotyl morphology on survival rate and growth of cucumber seedlings grafted on Cucurbita spp. Japan Agricultural Research Quarterly, v.26, n.4, p.259-263, 1993.

OLITTA, A.F.; MINAMI, K. Irrigação por gotejo em morango. Anais da Escola Superior de Agricultura “Luiz de Queiroz”, v.31, p.713-720, 1974.

OLIVEIRA, M. Gênese, classificação e extensão de solos afetados por sais. In: GUEYI, H.R.; QUEIROZ, J.E.; MEDEIROS, J.F. (Ed.) Manejo e controle da salinidade na agricultura irrigada. Campina Grande: UFPB, 1997. cap.1, p.1-35.

ORTELI, J.J. Effects of external salt concentrations on water relations in plants. Soil Science, v.105, p.216-221, 1968.

PAPADOPOULOS, A.P. Growing greenhouse seedless cucumbers in soil and in soilless media. 1994. 126p. (Agriculture and Agri-Food Canada Publication, $1902 / \mathrm{E})$ 
PEREIRA, J.A.; VILLA NOVA, N.A.; SEDIYAMA, G.C. Evapo(transpi)ração. Piracicaba: FEALQ, 1997. 183p.

PEREIRA, J.R.; VALDIVIESO, C.R.; CORDEIRO, G.G. Recuperação de solos afetados por sódio através do uso de gesso. In: SEMINÁRIO SOBRE O USO DE FOSFOGESSO NA AGRICULTURA, Brasília, 1985. Brasília, 1985. p.85-105.

PETERSEN, F.H. Water testing and interpretation. In: REED, D.W. (Ed.) Water, media, and nutrition for greenhouse crops. Batavia: Ball, 1996. cap.2, p.31-49.

PINTO, J.M.; SOARES, J.M.; CHOUDHURY, E.N. \& PEREIRA, J.R. Adubação via água de irrigação na cultura do melão. Pesquisa Agropecuária Brasileira, v.28, n.11, p.1263-1268, 1993.

RANZANI, G. Carta de solos do município de Piracicaba. Piracicaba: Centro de estudos de solos/ESALQ/USP, 1966. 85p.

RHOADES, J.D.; LOVEDAY, J. Salinity in irrigated agriculture. In: STEWART, D.R.; NIELSEN, D.R. (Eds.) Irrigation of agricultural crops. Madison: ASA/CSSA/SSSA, 1990. cap.36, p.1089-1142. (Agronomy, 30)

RHOADES, J.D.; KANDIAH, A.; MASHALI, A.M. The use of saline waters for crop production. Rome: FAO, 1992. 133p. (FAO. Irrigation and Drainage Paper, 48)

RICHARDS, L.A. Porous plate apparatus for measuring moisture retention and transmission by soil. Soil Science, v.66, p.105-110, 1948.

RICHARDS, L.A. (Ed.) Diagnosis and improvement of saline and alkali soils. Washington: United States Salinity Laboratory, 1954. 160p. (USDA. Agriculture Handbook, 60)

SCALOPPI, E.J.; BRITO, R.A.L. Qualidade da água e do solo para irrigação. Informe Agropecuário, n.139, p.80-94, 1986.

SHALHEVET, J. Using water of marginal quality for crop production: major issues. Agricultural Water Management, v.25, n.3, p.233-269, 1994.

SILVA, W.L.C.; CARRIJO, O.A.; MAROUELLI, W.A. Fertirrigação na EMBRAPA Hortaliças. In: FOLEGATTI, M.V. (Coord.) Fertirrigação: citrus, flores, hortaliças. Guaíba: Agropecuária, 1999. cap.5, p.433-440. 
SMITH, P.F. Mineral analysis of plant tissues. Annual Review of Plant Physiology, v.13, p.81-108, 1962.

SONNEVELD, C.; VOOGT, S.J. Effects of saline irrigation water on glasshouse cucumbers. Plant and Soil, v.49, n.3, p.595-606, 1978.

STANGHELLINI, C. Evapotranspiration in greenhouse with special reference to mediterranean conditions. Acta Horticulturae, v.335, p.296-304, 1993.

STANLEY, C.D.; MAYNARD, D.N. Vegetables. In: STEWART, D.R.; NIELSEN, D.R. (Eds.) Irrigation of agricultural crops. Madison: ASA/CSSA/SSSA, 1990. p. 921-950.

STEEL, R.G.D.; TORRIE, J.H. Principles and procedures of statistics: a biometrical approach. 2.ed. s.1.: Mcgraw-Hill, 1980. 633p.

SZABOLCS, I. Salt-affected soils. Florida: Library of Congress, 1989. 274p.

TRANI, P.E.; GROPPO, G.A.; SILVA, M.C.P.; MINAMI, K.; BURKE, T.J. Diagnóstico sobre a produção de hortaliças no estado de São Paulo. Horticultura Brasileira, v.15, n.1, p.19-24, 1997.

VAN DEN ENDE, J.; KOORNNEEF, P.; SONNEVELD, C. Osmotic pressure of the soil solution: determination and effects on some glasshouse crops. Netherlands Journal of Agricultural Science, v.23, n.3, p.181-190, 1975.

VAN DER MOLEN, W.H. Desalination of saline soils as a column process. Soil Science, v.81, p.19-27, 1956.

VAN GENUCHTEN, M.Th. A closed-form equation for predicting the hydraulic conductivity of unsaturated soils. Soil Science Society of America Journal, v.44, n.3, p.892-898, 1980.

VAN HOORN, J.W. Salt movement, leaching efficiency, and leaching requirement. Agricultural Water Management, v.4, n.4, p.409-428, 1981.

VAN HOORN, J.W.; VAN ALPHEN, J.G. Salinity control. In: RITZEMA, H.P. (Ed.). 2.ed. Drainage principles and applications. 2.ed. Wageningen: ILRI, 1994. cap.15, p.533-600. (ILRI Publication, 16) 
VERMEIREN, L.; JOBLING, G.A. Localized irrigation. Rome: FAO, 1984. 203p. (FAO. Irrigation and Drainage Paper, 36)

VIEIRA, D.B.; MANFRINATO, H.A. Irrigação por gotejamento em berinjela. Anais da Escola Superior de Agricultura “Luiz de Queiroz”, v.31, p.73-90, 1974.

VIVANCOS, A. D. Fertirrigacion. Madri: Mundi-Prensa, 1993. 217p.

VETANOVETZ, R.P. Tissue analysis and interpretation. In: REED, D.Wm. (Ed.)

Water, media, and nutrition for greenhouse crops. Batavia: Ball, 1996. cap.9, p.197-219.

WALTER, H. The adaptation of plants to saline soils. In: CONFERENCE OF SALINITY PROBLEMS IN THE ARID ZONE, Teheran, 1961. Proceedings. Teheran: UNESCO, 1961. p.129-134.

YARON, B. Water suitability for irrigation. In: YARON, E.; DANFORS, E.; VAADID, Y. (Eds.) Arid zone irrigation. Berlin: Springer-Verlag, 1973. p.71-88, 1973. (Ecological Studies, 5)

YINGJAJAVAL, S.; MARKMOON, C. Irrigation and fertilizer levels for the production of cucumber 'Puang'. Natural Sciences, v.27, n.2, p.142-152, 1993. /Resumo 6232 em Horticultural Abstracts, v.64, n.8, p.840, Ago. 1994/ 
APÊNDICES 
APÊNDICE 1. Quantidade de fertilizantes e sais aplicados nas irrigações (g.planta ${ }^{-1}$ ) para as diferentes salinidades da água de irrigação, ao longo do ciclo da cultura.

\begin{tabular}{|c|c|c|c|c|c|c|c|c|c|c|c|c|}
\hline \multirow[t]{2}{*}{ Semana } & \multirow[t]{2}{*}{$\overline{\mathrm{KNO}_{3}}$} & \multirow[t]{2}{*}{$\left(\mathrm{NH}_{4}\right)_{2} \mathrm{SO}_{4}$} & \multirow[t]{2}{*}{$\overline{\mathrm{Ca}\left(\mathrm{NO}_{3}\right)_{2}}$} & \multicolumn{3}{|c|}{$\mathrm{MgSO}_{4} \cdot 7 \mathrm{H}_{2} \mathrm{O}$} & \multirow{2}{*}{$\begin{array}{c}\mathrm{H}_{3} \mathrm{PO}_{4} \\
(\mathrm{ml})\end{array}$} & \multirow[t]{2}{*}{$\overline{\mathrm{KCl}}$} & \multicolumn{2}{|c|}{$\mathrm{NaCl}$} & \multicolumn{2}{|c|}{$\mathrm{CaCl}_{2} \cdot 2 \mathrm{H}_{2} \mathrm{O}$} \\
\hline & & & & S1 & S2 & S3 & & & S2 & S3 & S2 & S3 \\
\hline 1 & 0 & $\overline{0}$ & 0 & $\overline{0}$ & $\overline{0}$ & $\overline{0}$ & $\overline{0}$ & 0 & 0 & 0 & $\overline{0}$ & $\overline{0}$ \\
\hline 2 & 0 & 0 & 0 & 0 & 0 & 0 & 0 & 0 & 0 & 0 & 0 & 0 \\
\hline 3 & 0,09 & 0,33 & 1,29 & 0,11 & 1,36 & 2,87 & 0,10 & 0,66 & 1,90 & 3,70 & 0,53 & 3,11 \\
\hline \multirow{2}{*}{ 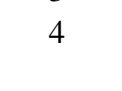 } & 0,09 & 0,33 & 1,29 & 0,11 & 1,36 & 2,87 & 0,10 & 0,66 & 1,90 & 3,70 & 0,53 & 3,11 \\
\hline & 0,07 & 0,26 & 1,03 & 0,08 & 1,09 & 2,29 & 0,08 & 0,53 & 1,52 & 2,96 & 0,43 & 2,49 \\
\hline \multirow[t]{2}{*}{5} & 0,07 & 0,26 & 1,03 & 0,08 & 1,09 & 2,29 & 0,08 & 0,53 & 1,52 & 2,96 & 0,43 & 2,49 \\
\hline & 0,64 & & 1,39 & 0,15 & 1,14 & 2,58 & 0,09 & 0,30 & 1,40 & 2,77 & 0,35 & 1,13 \\
\hline \multirow[t]{2}{*}{6} & 0,46 & & 1,00 & 0,11 & 0,82 & 1,85 & 0,11 & 0,38 & 1,74 & 3,46 & 0,43 & 1,41 \\
\hline & 0,55 & & & 0,13 & 0,98 & 2,22 & 0,08 & 0,27 & 1,25 & 2,47 & 0,31 & 1,01 \\
\hline \multirow[t]{2}{*}{7} & 0,48 & & & 0,11 & 0,86 & 1,94 & 0,10 & 0,33 & 1,50 & 2,98 & 0,37 & 1,21 \\
\hline & 0,52 & & & 0,12 & 0,91 & 2,07 & 0,08 & 0,28 & 1,31 & 2,60 & 0,32 & 1,06 \\
\hline \multirow[t]{2}{*}{8} & 0,55 & & & 0,13 & 0,98 & 2,21 & 0,09 & 0,30 & 1,40 & 2,77 & 0,35 & 1,13 \\
\hline & 0,38 & & & 0,09 & 0,68 & 1,53 & 0,10 & 0,32 & 1,49 & 2,96 & 0,37 & 1,20 \\
\hline \multirow[t]{3}{*}{9} & 0,58 & & & 0,14 & 1,02 & 2,31 & 0,07 & 0,22 & 1,03 & 2,05 & 0,26 & 0,83 \\
\hline & 0,50 & & & & 0,89 & 2,01 & 0,10 & 0,34 & 1,56 & 3,10 & 0,39 & 1,26 \\
\hline & 0,62 & & & & 1,09 & 2,47 & 0,09 & 0,29 & 1,36 & 2,69 & 0,34 & 1,09 \\
\hline \multirow[t]{2}{*}{10} & 0,60 & & & 0 , & 1,06 & 2,4 & 0,11 & 0,36 & 1,67 & 3,31 & 0,41 & 1,35 \\
\hline & 0,56 & & & & 1,16 & 2,7 & 10 & 0,35 & 1,85 & 3,81 & 0,53 & 1,64 \\
\hline \multirow[t]{2}{*}{11} & 0,57 & & & $\sigma$ & 1,18 & 2,74 & 0,10 & 0,33 & 1,72 & 3,55 & 0,49 & 1,53 \\
\hline & 0,67 & & 1, & 0 , & 1,40 & 3,25 & 0,10 & 0,33 & 1,74 & 3,59 & 0,50 & 1,55 \\
\hline \multirow[t]{2}{*}{12} & 0,77 & & 1 & 0, & 1,59 & 3,69 & 0,12 & 0,40 & 2,07 & 4,27 & 0,59 & 1,84 \\
\hline & 0,41 & & 0 & 0, & 0,86 & 2,00 & 0,13 & 0,45 & 2,35 & 4,85 & 0,67 & 2,09 \\
\hline \multirow[t]{2}{*}{13} & 0,63 & & 1 , & 0,1 & 1,25 & 2,53 & 0,08 & 0,28 & 1,36 & 2,51 & 0,37 & 1,03 \\
\hline & 0,71 & & 1, & 0,17 & 1,40 & 2,85 & 0,11 & 0,37 & 1,81 & 3,34 & 0,49 & 1,37 \\
\hline \multirow[t]{2}{*}{14} & 0,89 & 0 & 1, & 0,21 & 1,75 & 3,56 & 0,13 & 0,41 & 2,04 & 3,76 & 0,55 & 1,54 \\
\hline & 1,12 & 0 , & 2,4 & 0,27 & 2,20 & 4,48 & 0,16 & 0,52 & 2,54 & 4,69 & 0,69 & 1,92 \\
\hline \multirow[t]{2}{*}{15} & 0,97 & 0,73 & 2,14 & 0,23 & 1,90 & 3,87 & 0,20 & 0,65 & 3,20 & 5,92 & 0,87 & 2,42 \\
\hline & 1,02 & 0,77 & 2,25 & 0,24 & 2,00 & 4,08 & 0,17 & 0,56 & 2,76 & 5,11 & 0,75 & 2,09 \\
\hline \multirow[t]{3}{*}{16} & 0,90 & 0,68 & 2,00 & 0,22 & 1,29 & 3,37 & 0,18 & 0,59 & 2,27 & 5,06 & 0,43 & 2,01 \\
\hline & 0,88 & 0,67 & 1,96 & 0,21 & 1,27 & 3,31 & 0,16 & 0,52 & 2,01 & 4,48 & 0,38 & 1,78 \\
\hline & 0,62 & 0,46 & 1,36 & 0,15 & 0,88 & 2,30 & 0,16 & 0,51 & 1,97 & 4,40 & 0,37 & 1,75 \\
\hline 17 & 0,98 & 0,73 & 2,16 & 0,23 & 1,40 & 3,65 & 0,11 & 0,36 & 1,37 & 3,06 & 0,26 & 1,22 \\
\hline Total & 17,90 & 14,30 & 43,10 & 4,55 & 36,85 & 82,32 & 3,37 & 12,41 & 53,63 & 106,87 & 13,76 & 49,67 \\
\hline
\end{tabular}

Obs. As quantidades de $\mathrm{KNO}_{3},\left(\mathrm{NH}_{4}\right)_{2} \mathrm{SO}_{4}, \mathrm{Ca}\left(\mathrm{NO}_{3}\right)_{2}, \mathrm{H}_{3} \mathrm{PO}_{4} \mathrm{e} \mathrm{KCl}$ foram iguais para todas as águas. 
APÊNDICE 2. Relação entre a altura relativa da planta na qual a folha está inserida e sua respectiva área foliar aos 35 dias após o transplantio, para as nove plantas avaliadas (• Área da folha, — Área foliar média da planta).

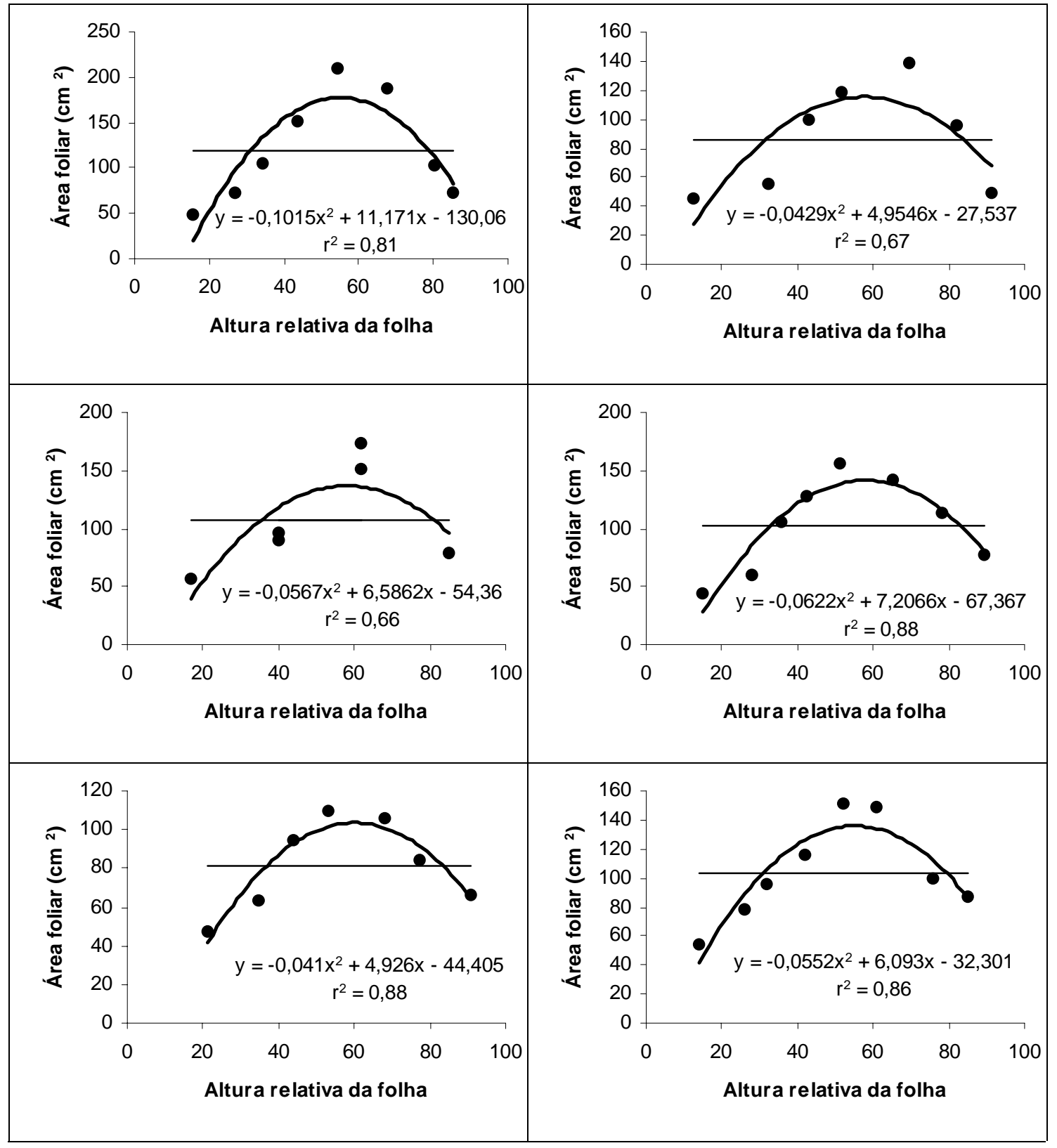


Apêndice 2. Continuação.

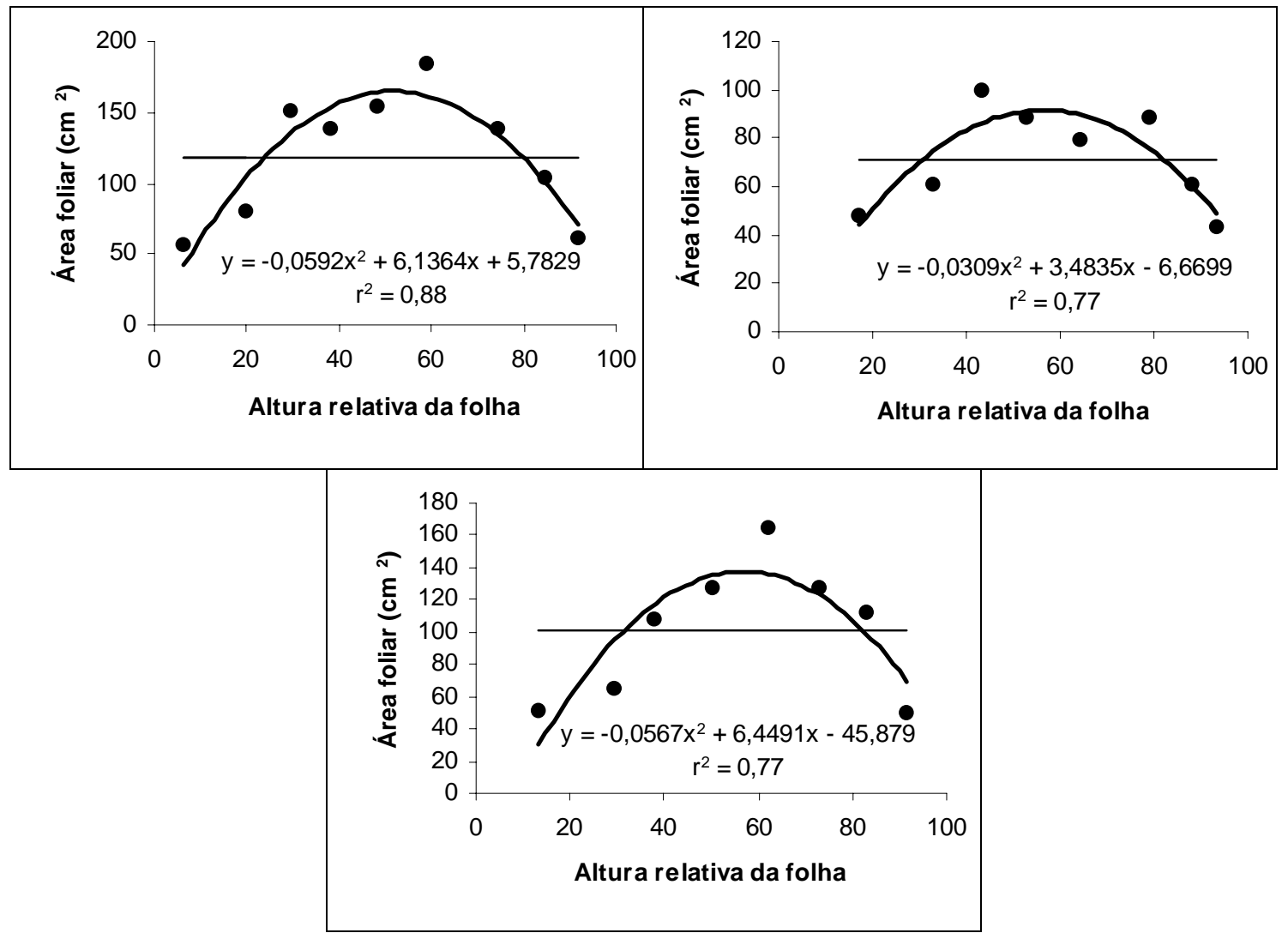


APÊNDICE 3. Relação entre a altura relativa da planta na qual a folha está inserida e sua respectiva área foliar aos 54 dias após o transplantio para as nove plantas avaliadas (• Área da folha, — Área foliar média da planta).

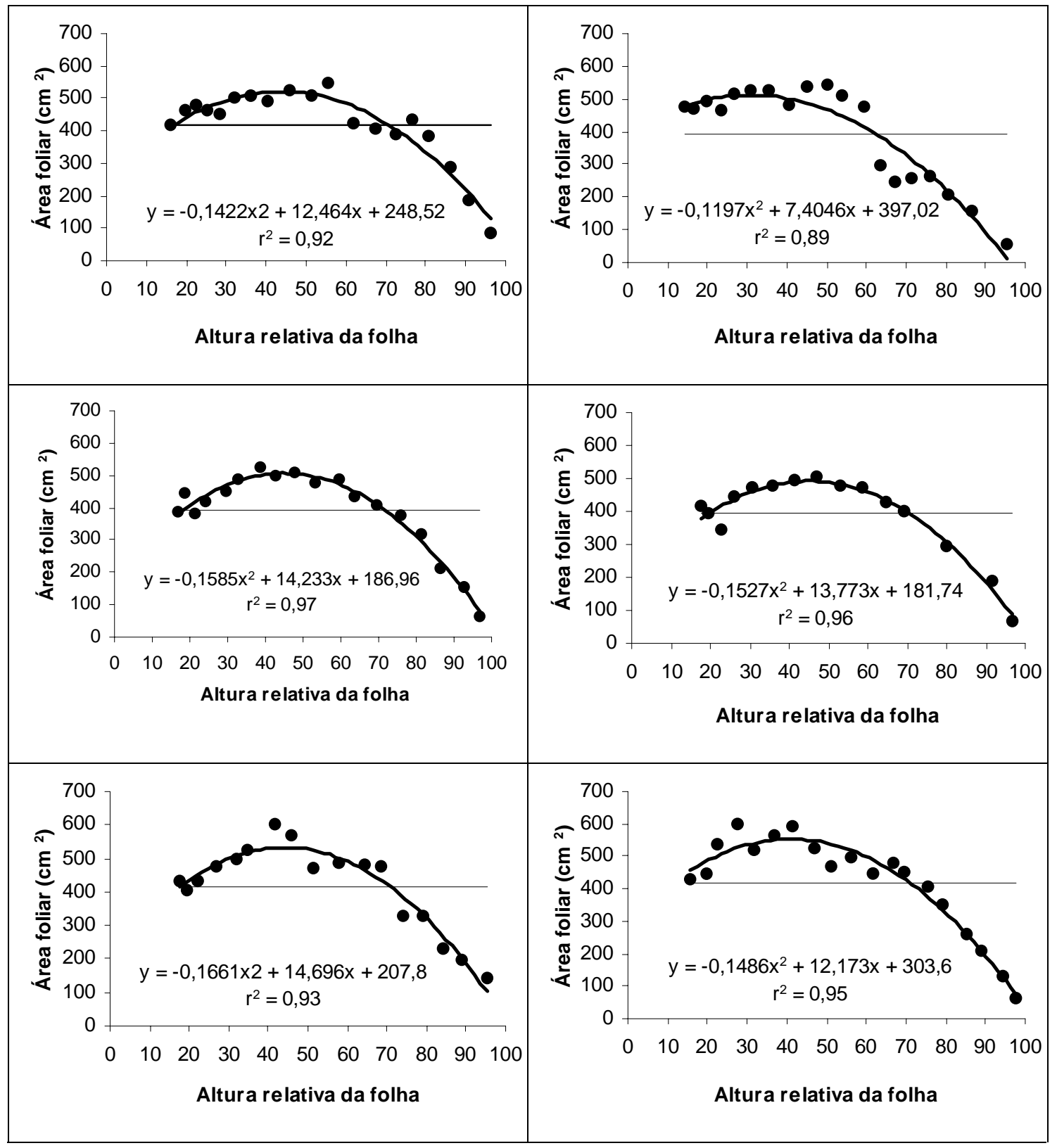


Apêndice 3. Continuação.

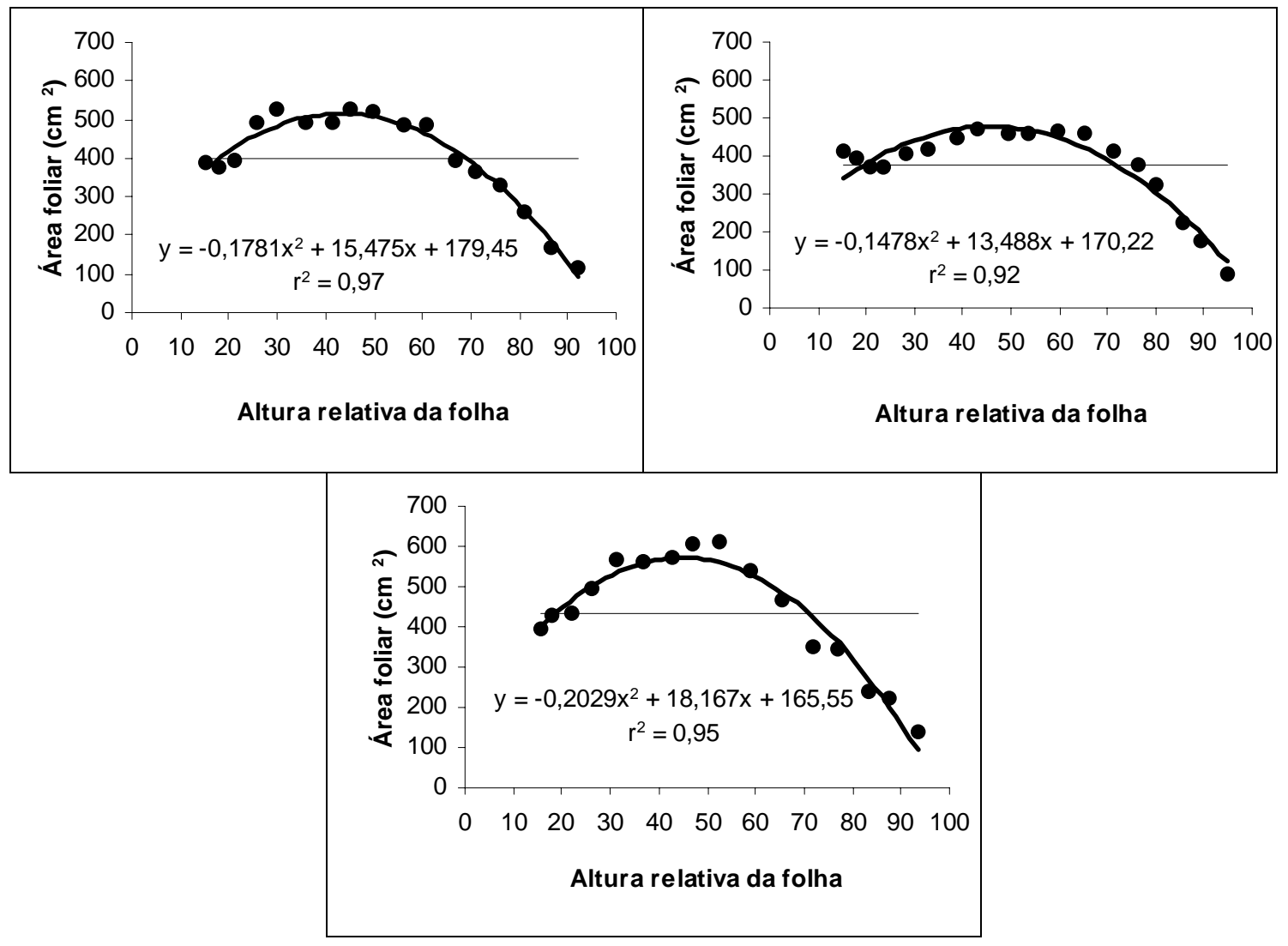


APÊNDICE 4. Área foliar média para cada altura relativa da folha na planta.

\section{DAT}
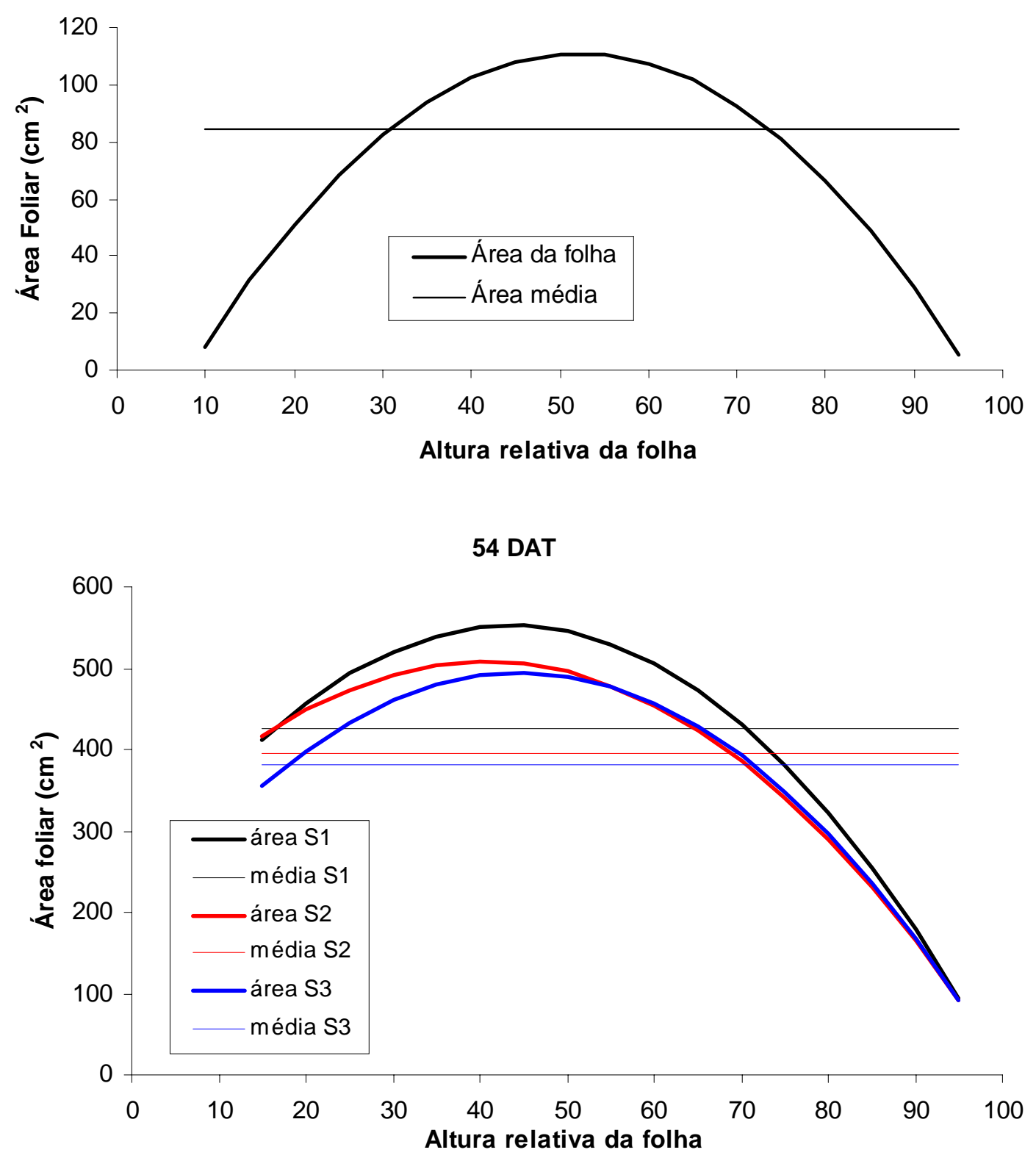
APÊNDICE 5. Relação entre a condutividade elétrica do extrato de saturação do solo (CEes) e a condutividade elétrica da solução 1:2 $\left(\mathrm{CE}_{1: 2}\right)$, para as profundidades de $0-20$ e $20-40 \mathrm{~cm}$.
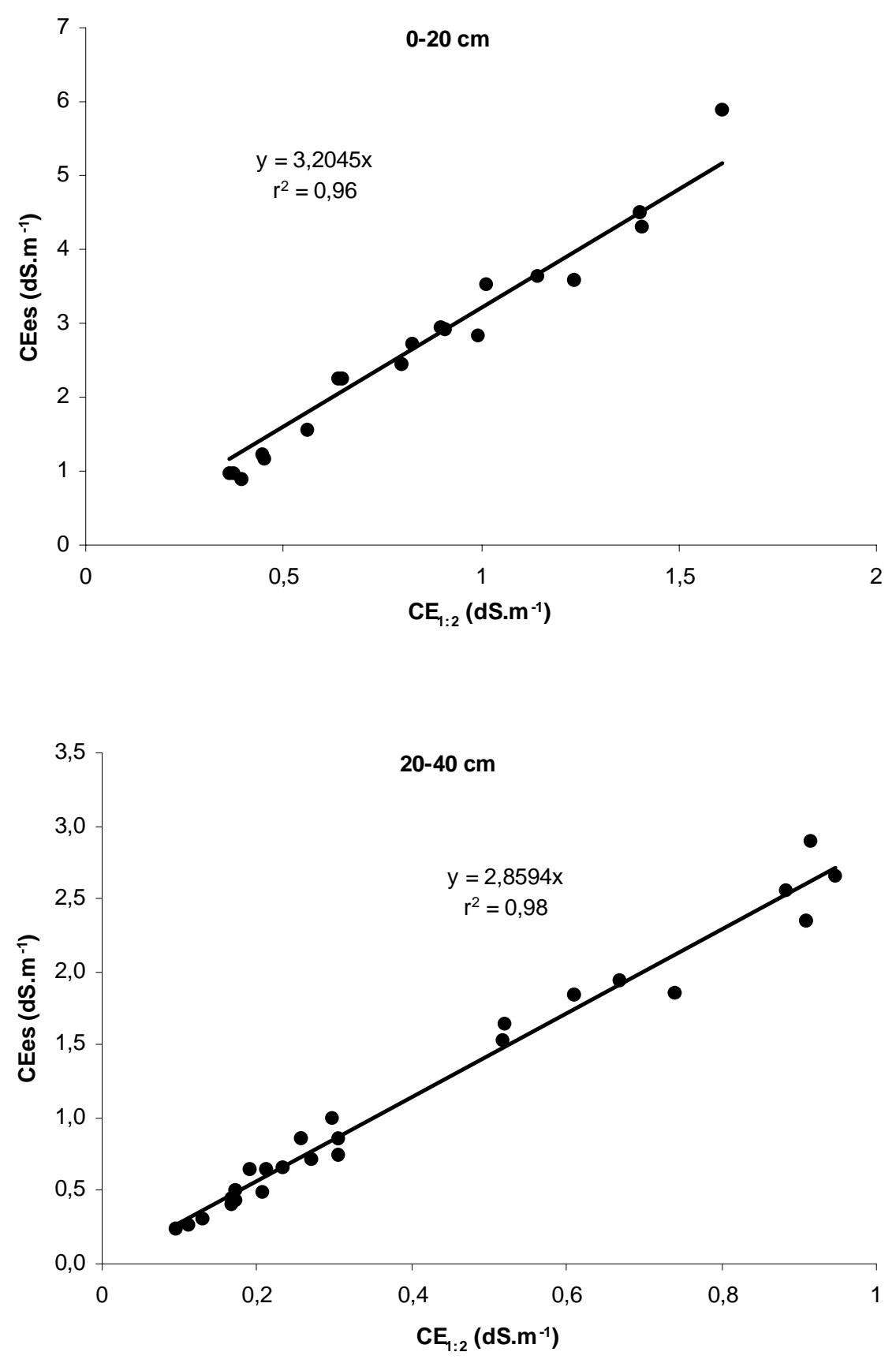


\section{APÊNDICE 6}

Módulo do potencial mátrico nas profundidades de 15 e $30 \mathrm{~cm}$ nos diferentes tratamentos 
101
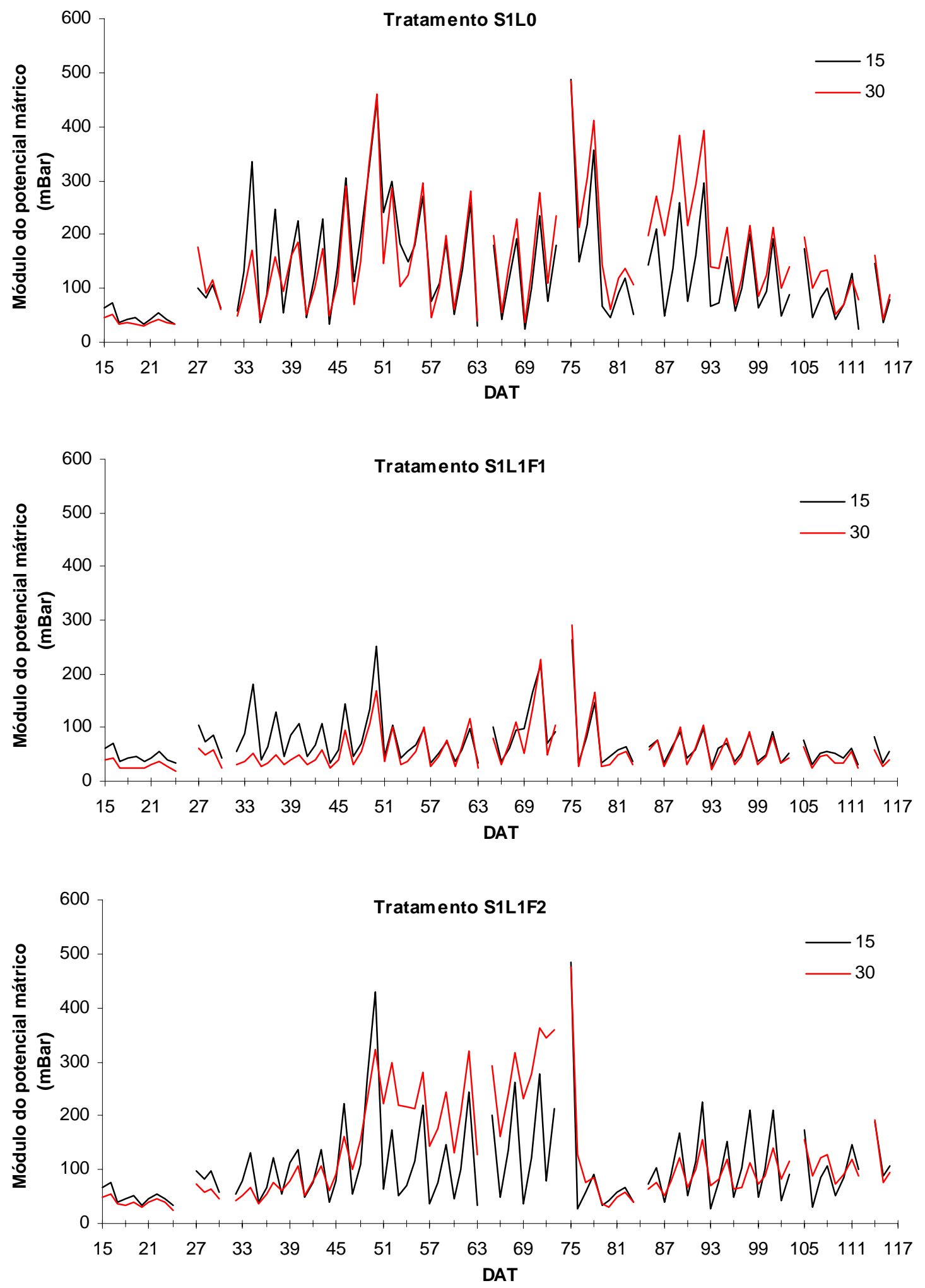
102
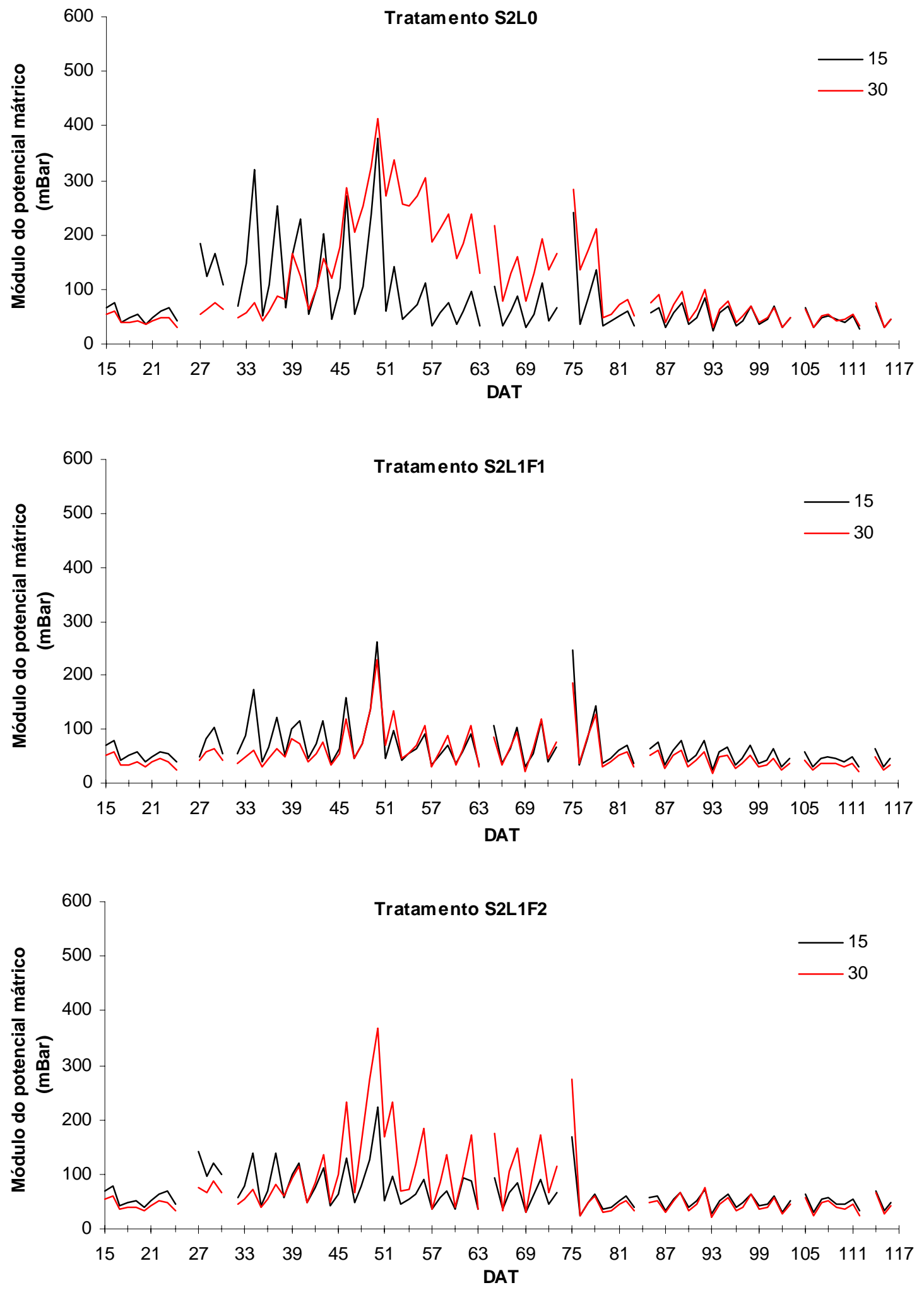

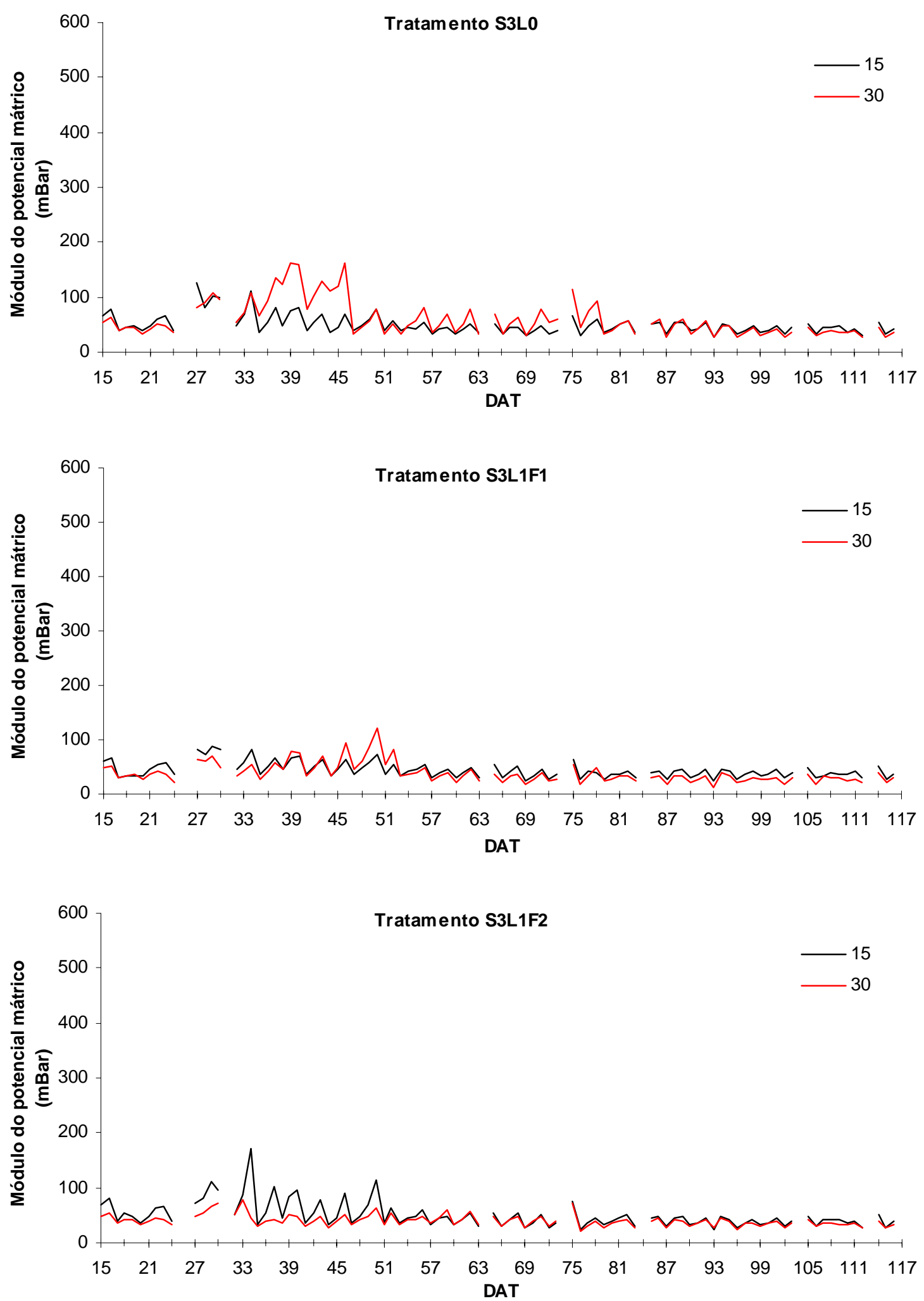
APÊNDICE 7. Resumo da ANAVA e médias da produção e número de frutos por planta, comercial e total, e peso médio de frutos comerciais de pepino, para as diferentes salinidades da água, lâminas de irrigação e frequências de aplicação da lâmina L1 .

\begin{tabular}{|c|c|c|c|c|c|}
\hline \multirow[b]{2}{*}{ Fator } & \multicolumn{5}{|c|}{ Estatística F } \\
\hline & $\begin{array}{l}\text { Prod. total } \\
\left(\mathrm{Mg}^{-h^{-1}}{ }^{-1}\right)\end{array}$ & $\begin{array}{l}\text { Prod. comercial } \\
\qquad\left(\mathrm{Mg} \cdot \mathrm{ha}^{-1}\right)\end{array}$ & $\begin{array}{c}\text { Peso médio dos frutos } \\
\left(\text { g.fruto }^{-1}\right)\end{array}$ & $\begin{array}{c}\text { Frutos totais } \\
\text { (frutos.planta }^{-1} \text { ) }\end{array}$ & $\begin{array}{l}\text { Frutos comerciais } \\
\text { (frutos.planta }^{-1} \text { ) }\end{array}$ \\
\hline - Níveis de salinidade (S) & 1,31 & 1,42 & 0,26 & 2,02 & 2,32 \\
\hline Linear & 2,59 & 2,64 & 0,24 & 4,02 & $4,40 *$ \\
\hline Quadr. & 0,02 & 0,19 & 0,29 & 0,01 & 0,23 \\
\hline - Lâmina (L) & 0,64 & 0,99 & 0,01 & 0,56 & 1,19 \\
\hline - Lâmina (L)/Frequência $(F)$ & 0,85 & 1,02 & 0,68 & 0,51 & 0,77 \\
\hline \multirow[t]{2}{*}{ - Interação (S x LF) } & 0,83 & 0,80 & 0,92 & 0,73 & 0,78 \\
\hline & & \multicolumn{4}{|c|}{ Média } \\
\hline \multicolumn{6}{|l|}{ - Níveis de salinidade } \\
\hline S1 & 109,0 & 99,7 & 132,4 & 33,8 & 29,9 \\
\hline S2 & 103,8 & 93,0 & 133,8 & 32,1 & 27,8 \\
\hline S3 & 98,5 & 89,4 & 133,5 & 30,1 & 26,5 \\
\hline \multicolumn{6}{|l|}{ - Lâmina (L) } \\
\hline L0 & 100,8 & 90,5 & 133,3 & 31,2 & 27,1 \\
\hline L1 & 106,5 & 95,9 & 133,2 & 32,4 & 28,6 \\
\hline \multicolumn{6}{|l|}{ - Lâmina (L)/Frequência (F) } \\
\hline L1F1 & 101,9 & 92,7 & 132,0 & 31,8 & 28,1 \\
\hline L1F2 & 111,1 & 99,0 & 134,4 & 33,0 & 29,1 \\
\hline
\end{tabular}

* Significativo ao nível de 0,05 de probabilidade pelo teste $\mathrm{F}$. 